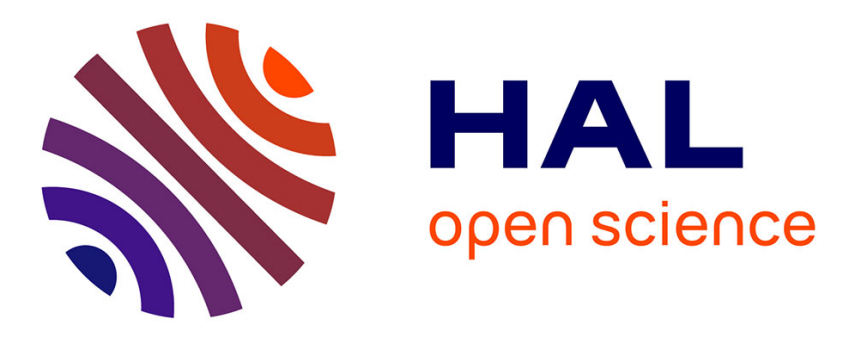

\title{
Organocatalytic Multicomponent Reactions of 1,3-Dicarbonyls for the Synthesis of Enantioenriched Heterocycles
}

Haiying Du, Yohan Dudognon, M. del Mar Sanchez Duque, Sébastien

Goudedranche, Damien Bonne, Jean Rodriguez, Xavier Bugaut, Thierry

Constantieux

\section{To cite this version:}

Haiying Du, Yohan Dudognon, M. del Mar Sanchez Duque, Sébastien Goudedranche, Damien Bonne, et al.. Organocatalytic Multicomponent Reactions of 1,3-Dicarbonyls for the Synthesis of Enantioenriched Heterocycles. Synthesis: Journal of Synthetic Organic Chemistry, 2016, 48, pp.3479-3503. $10.1055 / \mathrm{s}-0035-1561490$. hal-01415048

\author{
HAL Id: hal-01415048 \\ https://hal.science/hal-01415048
}

Submitted on 12 Dec 2016

HAL is a multi-disciplinary open access archive for the deposit and dissemination of scientific research documents, whether they are published or not. The documents may come from teaching and research institutions in France or abroad, or from public or private research centers.
L'archive ouverte pluridisciplinaire HAL, est destinée au dépôt et à la diffusion de documents scientifiques de niveau recherche, publiés ou non, émanant des établissements d'enseignement et de recherche français ou étrangers, des laboratoires publics ou privés. 


\section{Organocatalytic Multicomponent Reactions of 1,3-Dicarbonyls for the Synthesis of Enantioenriched Heterocycles}

\author{
Haiying $\mathrm{Du}^{\mathrm{a}, \mathrm{b}, \neq}$ \\ Yohan Dudognon a, \\ Maria del Mar Sanchez Duque \\ Sébastien Goudedranchea,c \\ Damien Bonne ${ }^{a}$ \\ Jean Rodriguez ${ }^{\mathrm{a}}$ \\ Xavier Bugauta* \\ Thierry Constantieux ${ }^{*}$ \\ aAix Marseille Université, Centrale Marseille, CNRS, iSm2 UMR \\ 7313, 13397, Marseille, France. \\ "Present address: College of Materials and Chemistry \& \\ Chemical Engineering, Chengdu University of Technology, \\ Chengdu 610059, China \\ 'Present address: Département de Chimie Organique, \\ Université de Genève, Quai Ernest Ansermet 30, 1211 Genève \\ 4, Switzerland. \\ 'Both authors contributed equally. \\ xavier.bugaut@univ-amu.fr, thierry.constantieux@univ-amu.fr
}

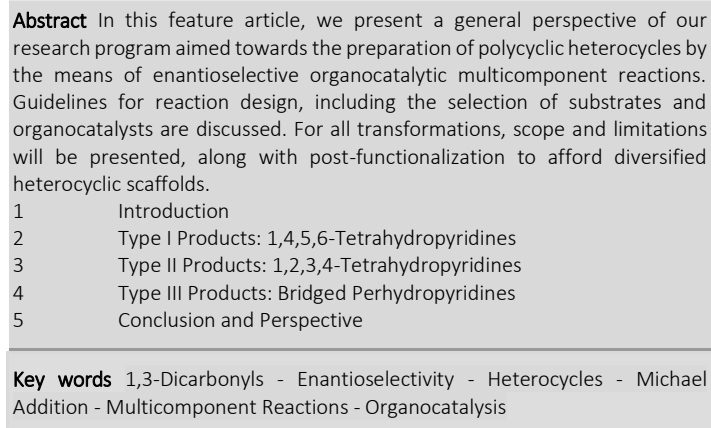

\section{Introduction}

Heterocycles are key synthetic targets in view of their ubiquitous presence in bioactive molecules. ${ }^{1}$ When these molecules bear stereogenic elements, it is of utter importance to control their configuration as the stereochemical information may have a deep influence on their interaction with the biological target. In that prospect, organocatalysis ${ }^{2}$ has emerged as a very powerful tool since it allows the stereoselective synthesis of a large variety of heterocyclic compounds with high enantiomeric excesses. ${ }^{3}$ Among these heterocycles, polyhydropyridines are both interesting synthetic targets and an inspiration for the development of new patterns of reactivity. Thus, many new strategies were designed following the seminal contributions of Renaud's and Gong's research groups using Brønsted acid catalysis $^{4}$ and Hayashi's and Jørgensen's teams by applying iminium activation. ${ }^{5}$ When we became interested in this area of research, we hypothesized that multicomponent reactions, ${ }^{6}$ that is to say the initial simultaneous introduction of at least three reaction partners that will be integrated in the target product, would be an interesting tool to efficiently prepare new enantioenriched polyhydropyridine motifs. $\beta$-Dicarbonyl compounds are generally used as pronucleophiles in the synthesis of these heterocycles and their polyfunctional nature makes them ideal substrates for multiple bond-forming transformations (MBFT's) including domino processes and multicomponent reactions. ${ }^{7}$

Our starting point was the combination of an $\alpha, \beta$-unsaturated aldehyde $\mathbf{A}$, a $\beta$-dicarbonyl $\mathbf{B}$ and a functionalized amine $\mathbf{C}$ in the presence of a chiral non-racemic organocatalyst (Scheme 1). After the initial catalyst-controlled enantioselective Michael addition that forges the first stereogenic center, ${ }^{8}$ the amine functionality combines with the aldehyde and the ketone of the Michael adduct $\mathbf{D}$ affording 1,4-dihydropyridine $\mathbf{E}$ with loss of two molecules of water. In 1,4-dihydropyridine $\mathbf{E}$, each side of the dienamine motif can tautomerize to the corresponding iminium ion to deliver reactive intermediates $\mathbf{F}$ and $\mathbf{F}^{\prime}$, whose trapping by the pendant nucleophile delivers fused 1,4,5,6tetrahydropyridines $\mathbf{G}$ (Type I) ${ }^{9}$ and 1,2,3,4-tetrahydropyridines G' (Type II), bearing two or three stereogenic centers, respectively. ${ }^{10}$ When a secondary amide group is present on the substrate, a zwitterionic intermediate $\mathbf{H}$ can then be envisaged, whose cyclization leads to the formation of bridged perhydropyridines I (Type III) incorporating up to four stereogenic carbon atoms. ${ }^{11}$ of course, for this last family of products, the order of the cyclization events can also be interchanged. In principle, all the elemental steps of the different reaction pathways (acido-basic exchanges, Michael additions, dehydrations, tautomerizations and iminium ion trappings) can be reversible. In addition to their inherent step-economic nature and high synthetic efficiency for the fast elaboration of highly complex architectures, multicomponent reactions also offer interesting opportunities in terms of efficiency and stereoselectivity. Indeed, if one or several of the bond-forming events are kinetically and/or thermodynamically favored, this could help driving the whole sequence towards the efficient 
<smiles>[R]C=CC=O</smiles>

A B Type I

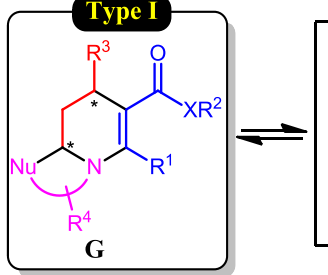

$\ominus_{N}$<smiles>[Y12]C(=O)C1=C([R])N(C([R])([Y])C(=O)O)C=CC1[Y]</smiles><smiles>[R1]C(=O)C(C([R])=O)C([Y])CC=O</smiles>

D<smiles>[R1]C(N)(N)N</smiles>

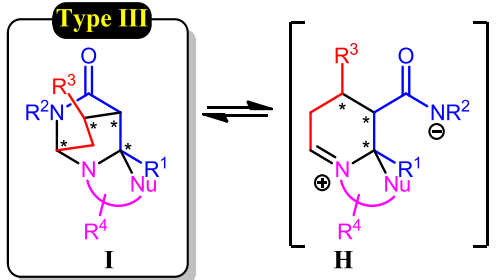

H $\sqrt{\|}-2 \mathrm{H}_{2} \mathrm{O}$ $(X=N H$, $R^{2}=E W G$ ) Type II<smiles></smiles><smiles></smiles>

$\mathbf{F}^{\prime}$

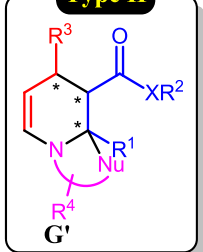

Scheme 1. General reactivity pattern for the organocatalytic multicomponent synthesis of enantioenriched heterocycles.

formation of the desired product. Moreover, for enantioselective transformations, the steps that follow the enantiodiscriminating one can prevent its reversibility, thereby avoiding the racemization of the product, which was for example already noticed in a related stepwise synthesis of 1,4-dihydropyridines. ${ }^{5 b}$ However, two important conditions have to be respected for the design of multicomponent enantioselective transformations: (i) the third reaction partner should not interact in a deleterious way with the organocatalyst; (ii) all the steps of the sequence should occur fast enough in similar reaction conditions, which might become problematic, especially when low temperature is required to ensure good enantioselection during the Michael addition.

Complementary to scarce reports by other groups for the inclusion of $\beta$-dicarbonyls in organocatalytic enantioselective multicomponent transformations, ${ }^{7 \mathrm{~h}, 12}$ we have recently disclosed independent synthetic routes towards three families of enantioenriched heterocycles (Figure 1): pyrrolopiperazine derivatives with a 1,4,5,6-tetrahydropyridine motif (Type I), ${ }^{9}$ 1,2,3,4-tetrahydropyridines (Type II) ${ }^{10}$ and 2,6diazabicyclo[2.2.2] octan-3-ones (2,6-DABCOs, Type III). ${ }^{11,13,14}$ In this Feature Article, we wish to provide the readers, with a general overview of our reaction design to help trigger new development in this area. The structure of the different reaction<smiles>[R]OC(=O)C1=C([R])N2CCn3cccc3C2C[C@H]1[R]</smiles>

1,4,5,6-Tetrahydropyridines (Pyrrolopiperazines) (Type I)

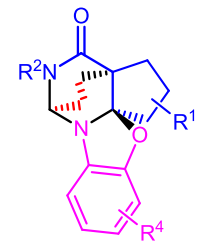

Bridged Perhydropyridines (2,6-DABCOs)

(Type III)

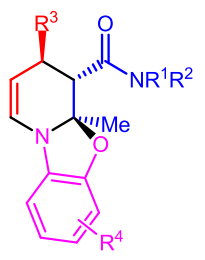

1,2,3,4-Tetrahydropyridines (Type II)
Figure 1. Families of polyheterocycles discussed in this article. partners, especially the $\beta$-dicarbonyl and the pendant nucleophile on the amine, the mode of action of the organocatalyst and the reaction conditions are among the key factors that control the chemo- and enantioselective formation of one defined product. Scope, limitations and bridging between the different patterns of reactivity will be discussed. Moreover, postfunctionalizations of the products to afford structurally diverse heterocyclic scaffolds will also be presented.

\section{Type I Products: 1,4,5,6-Tetrahydropyridines (Pyrrolopiperazines)}

With the general reactivity pattern presented in Scheme 1 in mind, Type I products first appeared as the easiest synthetic targets. Indeed, tautomerization of the common intermediate $\mathbf{E}$ should favor the formation of iminium ion $\mathbf{F}$, which exhibits higher conjugation and whose electrophilic reactive center is less hindered than in its congener $\mathbf{F}^{\prime}$. A number of similar organocatalytic sequences involving a secondary aminecatalyzed Michael addition followed by the cyclization of a pendant nucleophile, either an electron-rich aromatic ring ${ }^{15}$ or an heteroatom, ${ }^{16}$ had already been described before but in a stepwise fashion, with the requirement of a strong and/or stoichiometric acid. As the presence of this additive was likely to damage the activity of the secondary amine catalyst, we set out to find a nucleophilic moiety that could react even in the absence of an acid. Since the pyrrole ring is known to exhibit strong nucleophilicity, which is further increased when it is alkylated, ${ }^{17}$ it was selected as the third reaction partner, with the aim to trap the iminium intermediate through a Pictet-Spengler-type cyclization. Pleasingly, mixing equimolar ratios of an $\alpha$ methylene $\beta$-ketoester $\mathbf{1}$ and $N$-(2-aminoethyl)pyrrole (3) with a 1.5 -fold excess of an enal 2 in the presence of Hayashi-Jørgensen catalyst $\mathbf{4}$ delivered the expected polycyclic structure $\mathbf{5}$ (Scheme 2). ${ }^{9 a}$ It should be noted that other classical secondary amine organocatalysts performed very poorly in this transformation and that trifluorotoluene as the solvent had an appreciable positive impact on the enantioselectivity of the reaction. The overall transformation allowed the formation of four new bonds, a tricyclic pyrrolopiperazine core and two stereogenic carbon atoms. Twenty different products with possibilities of variation 
on all three reaction partners were prepared in moderate yields because of the fragility of the pyrrole unit.

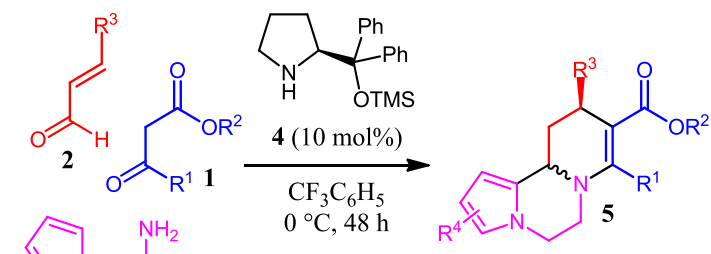

Type I products - Iminium activation -20 examples

3 4 new bonds: $31-70 \%$ yield 2 stereogenic carbon atoms: $\sim 1: 1 d r, 74-99 \%$ ee

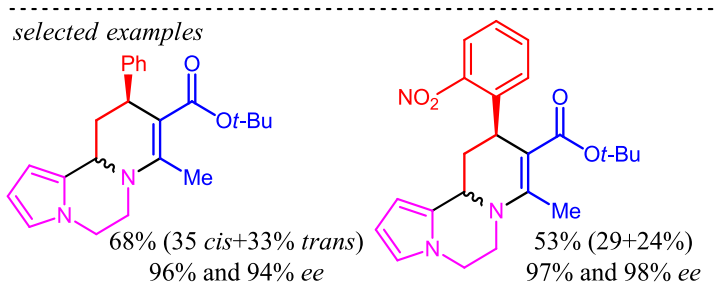<smiles>CCOC(=O)C1=C(c2ccccc2)[C@H](c2ccccc2)C[C@H]2c3ccc(-c4ccccc4)n3CCN12</smiles>

Scheme 2. Pyrrolopiperazines incorporating a 1,4,5,6tetrahydropyridine core: previous results. ${ }^{9 a}$

If enantioselectivities were generally good to excellent (74-99\% $e e$ ), there was no diastereoselectivity during the Pictet-Spengler cyclization, but this drawback was counterbalanced by the fact that the two diastereomers could generally be separated by flash chromatography. To widen the application range of this transformation, we then wished to pursue the four following directions (Scheme 3):

(i) Why is there no diastereoselectivity and is there a way to solve this issue?

(ii) Is it possible to replace the alkyl or aryl group at $\mathrm{R}^{3}$ by a more functionalized one?

(iii) Could the $\beta$-ketoester be replaced by other pronucleophiles?

(iv) Could other bis-nucleophilic units than $\mathrm{N}$-(2aminoethyl)pyrroles participate in the reaction?

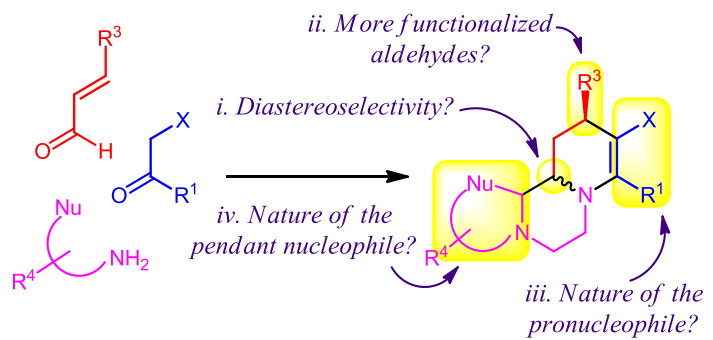

Scheme 3. 1,4,5,6-Tetrahydropyridines: open questions.

\subsection{Diastereoselectivity of the reaction}

Before studying the diastereoselectivity of the process, it was necessary to determine whether the second stereogenic carbon atom was forged under kinetic or thermodynamic control. When diastereomerically pure cis-5a was placed back in the reaction conditions in the presence of a substituted $\mathrm{N}$-(2aminoethyl)pyrrole $\mathbf{3 b}$ (Scheme 4a), it was recovered unchanged (neither epimerization, nor cross-over product $\mathbf{5 b}$ ), pointing towards an irreversibility of the cyclization process. In related enantioselective Michael addition-Pictet-Spengler domino processes, an improvement of the diastereoselectivity was observed by the addition of a strong acid at the end of the reaction. ${ }^{15 a, 18}$ In the present case, treatment of $\mathbf{5 a}$ as a $1.4: 1$ mixture of diastereomers with an acid resulted either in no evolution or in its complete degradation (Scheme 4b). Thus, diastereoselectivity in this system seems difficult to control since both faces of iminium ion intermediate are not enough differentiated by the relatively distant stereogenic carbon atom.
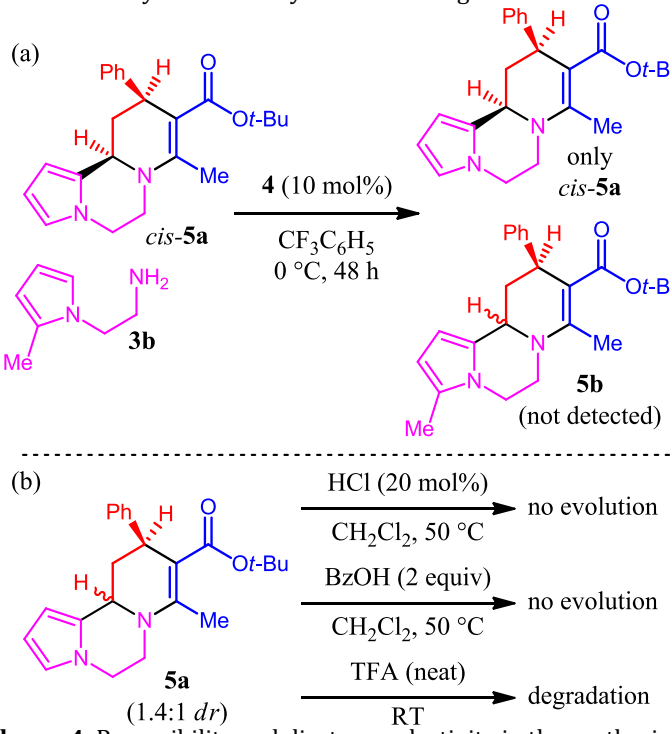

Scheme 4. Reversibility and diastereoselectivity in the synthesis of pyrrolopiperazines.

\subsection{Reaction with ethyl 4-oxobut-2-enoate}

In our initial studies, we had used aldehydes bearing alkyl, vinyl and (hetero)aryl substituents at their $\beta$ position. To broaden the synthetic usefulness of the present transformation, we became interested in the use of ethyl 4-oxobut-2-enoate 2c (Scheme 5). Directly applying the standard multicomponent conditions or trying to alter them (use of various solvents: $\mathrm{CH}_{2} \mathrm{Cl}_{2}, \mathrm{CH}_{3} \mathrm{CN}$; reaction at room temperature; addition of benzoic acid as cocatalyst) failed to provide the expected product. We surmised that the high electrophilicity of this enal might result in side reactions with the other reaction partners. To solve this issue, we came back to a one-pot two-step process: pleasingly, if $\mathrm{N}$-(2aminoethyl)pyrrole (3a) was added after two days and the reaction mixture kept at $0{ }^{\circ} \mathrm{C}$ for an additional day, pyrrolopiperazine 5c was isolated in $45 \%$ yield as a $\sim 1.2: 1$ diastereomeric mixture with high enantioselectivities $(94 \%$ and $93 \%$ ee for each diastereomer, respectively). 


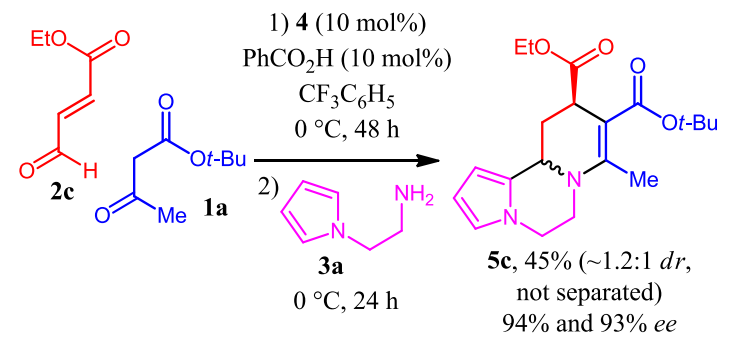

Scheme 5. Enantioselective synthesis of pyrrolopiperazine 5c from ethyl 4-oxobut-2-enoate 2c.

\subsection{More diversified Michael pronucleophiles}

Our initial studies were limited to the use of $\beta$-ketoesters as pronucleophiles. However, a large variety of Michael donors have demonstrated the ability to add enantioselectively to enals activated as the corresponding iminium ions by a secondary amine catalyst. ${ }^{19}$ A certain number of these compounds of type 6a-h were evaluated and many of them proved to be able to deliver the corresponding pyrrolopiperazine products $\mathbf{7 a a - h a}$ $\mathbf{7 a d}$ and $\mathbf{7 f e}$ at the cost of slight modifications of the standard reaction conditions (Table 1 ). With acetylacetone (6a) as the pronucleophile, a low yield of product 7aa and only moderate enantioselectivity were obtained in the standard reaction

Table 1. Scope of various Michael donors for the enantioselective multicomponent synthesis of pyrrolopiperazines. [a]

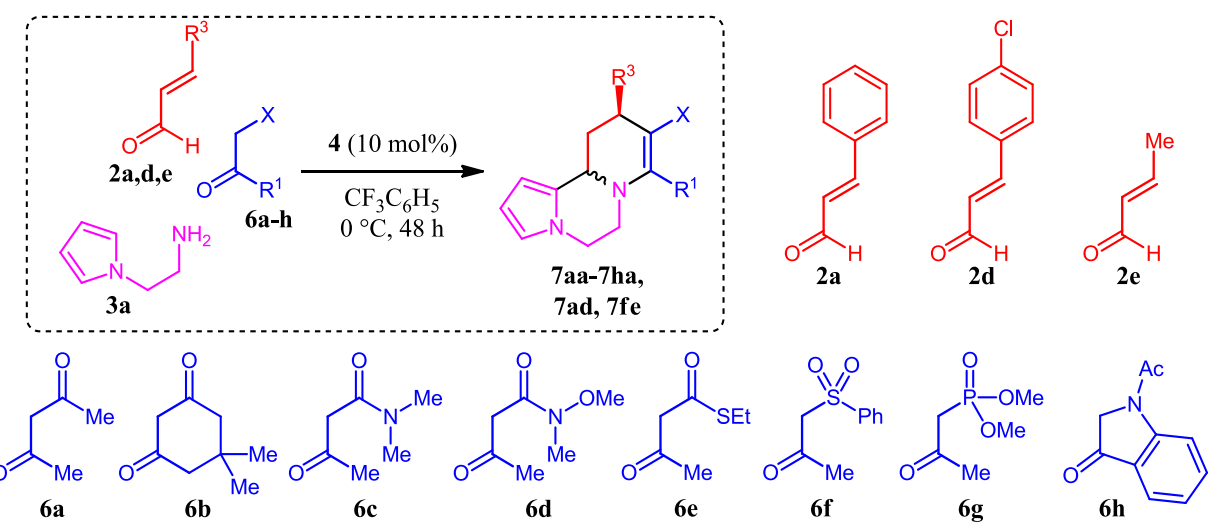

\begin{tabular}{|c|c|c|c|c|c|c|}
\hline Entry & $\begin{array}{c}\text { Michael } \\
\text { donor }\end{array}$ & Enal & Changes from the standard reaction conditions & Product & Yield (cis+trans) ${ }^{[\mathrm{b}]}$ & $e e^{[c]}$ \\
\hline 1 & $6 a$ & $2 a$ & none & $7 \mathbf{a a}$ & $<30 \%$ & $72 \%$ and n.d.[d] \\
\hline 2 & $6 a$ & $2 a$ & $\mathrm{PhCO}_{2} \mathrm{H}(10 \mathrm{~mol} \%)$ & $7 \mathbf{a a}$ & $60 \%$ & $82 \%$ and n.d.[d] \\
\hline 3 & $6 a$ & $2 a$ & $\mathrm{PhCO}_{2} \mathrm{H}(20 \mathrm{~mol} \%), \mathrm{CH}_{2} \mathrm{Cl}_{2}$ as solvent, $-10^{\circ} \mathrm{C}$ & $7 \mathbf{a a}$ & $68 \%(45+23 \%)$ & $94 \%$ and $91 \%$ \\
\hline 4 & $\mathbf{6 a}$ & 2d & $\mathrm{PhCO}_{2} \mathrm{H}(20 \mathrm{~mol} \%), \mathrm{CH}_{2} \mathrm{Cl}_{2}$ as solvent, $-10^{\circ} \mathrm{C}$ & 7 ad & $67 \%(38+29 \%)$ & $91 \%$ and $91 \%$ \\
\hline 5 & 6b & $2 a$ & none & 7ba & $\sim 50 \%[\mathrm{e}]$ & $64 \%$ and n.d.[d] \\
\hline 6 & $6 \mathbf{b}$ & $2 a$ & $\mathrm{PhCO}_{2} \mathrm{H}(20 \mathrm{~mol} \%)$ & $7 \mathbf{b a}$ & $\sim 40 \%[\mathrm{e}]$ & $36 \%$ and n.d. $[\mathrm{d}]$ \\
\hline 7 & 6c & $2 a$ & none & $7 \mathbf{c a}$ & $25 \%$ (only trans) & $92 \%$ \\
\hline 8 & 6d & $2 a$ & none & 7da & $28 \%$ (only trans) & $88 \%$ \\
\hline 9 & $6 e$ & $2 a$ & none & 7ea & $50 \%(21+29 \%)$ & $49 \%$ and $54 \%$ \\
\hline 10 & 6f & $2 a$ & none & $7 \mathrm{fa}$ & no product & - \\
\hline 11 & 6f & $2 e$ & none & $7 \mathrm{fe}$ & $\sim 45 \%[\mathrm{e}]$ & $77 \%$ and $76 \%$ \\
\hline 12 & $6 f$ & $2 e$ & $\mathrm{PhCO}_{2} \mathrm{H}(20 \mathrm{~mol} \%)$, THF as solvent & $7 \mathrm{fe}$ & $\sim 55 \%[\mathrm{e}]$ & $60 \%$ and $61 \%$ \\
\hline 13 & $6 f$ & $2 e$ & reaction time: $96 \mathrm{~h}$ & $7 \mathrm{fe}$ & $\sim 50 \%(31+22 \%)^{[\mathrm{e}]}$ & $89 \%$ and $85 \%$ \\
\hline 14 & $6 \mathrm{~g}$ & $2 \mathbf{a}$ & none & 7ga & no product & - \\
\hline 15 & 6h & $2 a$ & none & 7ha & $\sim 65 \%(1.6: 1 d r)^{[\mathrm{e}, \mathrm{f}]}$ & $80 \%$ and $80 \%$ \\
\hline 16 & $6 \mathrm{~h}$ & $2 a$ & $\mathrm{CH}_{2} \mathrm{Cl}_{2}$ as solvent & 7 ha & $68 \%(1.5: 1 d r)^{[\mathrm{f}]}$ & $88 \%$ and $87 \%$ \\
\hline
\end{tabular}

aAll reactions were run using $\mathbf{6 a - h}(0.200 \mathrm{mmol}, 1$ equiv), 2a,d,e $(0.300 \mathrm{mmol}, 1.5$ equiv), 3a (0.200 mmol, 1 equiv) and catalyst 4 (0.020 mmol, 0.1 equiv) in $\mathrm{CF}_{3} \mathrm{C}_{6} \mathrm{H}_{5}(2.5 \mathrm{~mL})$ for $48 \mathrm{~h}$ at $0{ }^{\circ} \mathrm{C}$. Changes from these standard reaction conditions are notified in the table. bYields of analytically pure isolated products (yields between brackets are those of the cis and trans diastereomers, respectively, when they could be separated). "Enantiomeric excesses (ee) were determined by HPLC analysis on a chiral stationary phase. dDuring optimization studies, only the $e e$ of the cis diastereomer was determined, as both of them usually have similar values. eProduct purities $\sim 90 \%$. The diastereomers could not be separated and the diastereomeric ratios $(d r)$ were determined by ${ }^{1} \mathrm{H}$ NMR spectroscopy analysis after purification. 


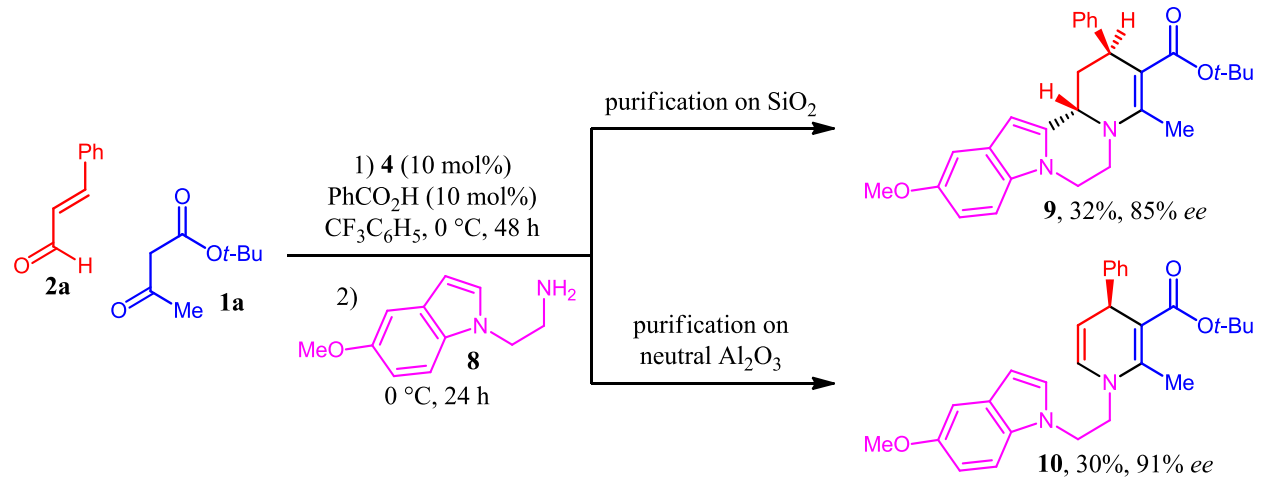

Scheme 6. Use of $\mathrm{N}$-(2-aminoethyl)indole derivative 8.

conditions (Entry 1). However, the addition of benzoic acid as a co-catalyst proved beneficial for the product formation (Entry 2). Ultimately, replacing $\mathrm{CF}_{3} \mathrm{C}_{6} \mathrm{H}_{5}$ by $\mathrm{CH}_{2} \mathrm{Cl}_{2}$ as the solvent and decreasing the reaction temperature to $-10{ }^{\circ} \mathrm{C}$ delivered 7 aa with yields and enantioselectivities similar to those obtained with the $\beta$-ketoesters (Entry 3 ). Those optimized reaction conditions transposed efficiently to prepare 7ad from 4-chlorocinnamaldehyde (2d) (Entry 4). On the contrary, cyclic diketones such as dimedone (6b) proved to be more challenging substrates: only moderate yields and enantioselectivities were obtained for $\mathbf{7} \mathbf{b a}$, and the addition of an acidic co-catalyst was deleterious (Entries 5 and 6). We have recently reported that tertiary $\beta$-ketoamides can be potent Michael donors that can add to nitroolefins under hydrogen-bonding organocatalysis with high enantio- and diastereoselectivities. ${ }^{20}$ We were intrigued whether they could also participate in the multicomponent organocatalytic synthesis of pyrrolopiperazines. Both $\mathrm{N}, \mathrm{N}$ dimethyl and Weinreb $\beta$-ketoamides $\mathbf{6 c}$ and $\mathbf{6 d}$ reacted in the standard reaction conditions (Entries 7 and 8): even though both diastereomers are present in the crude reaction mixture, only the trans diastereomers of products $\mathbf{7} \mathbf{c a}$ and $\mathbf{7 d a}$ could be obtained pure, and their enantiomeric excesses were satisfying. $\beta$-Ketothioester 6e was also a potent pronucleophile in this transformation, but product 7ea was formed only with a moderate enantioselectivity. The next step was to substitute the ester moiety by a sulfone or a phosphonate. Both substrates 6 f and $\mathbf{6 g}$ failed to react when cinnamaldehyde (2a) was used as the electrophile (Entries 10 and 14). However, based on literature precedents showing that $\mathbf{6 f}$ reacts preferentially with enals bearing an aliphatic group at the $\beta$ position, ${ }^{21}$ crotonaldehyde (2e) was combined with $\mathbf{6} \mathbf{f}$ and $\mathbf{3 a}$ in the standard reaction conditions (Entry 11): this time, product $\mathbf{7 f e}$ was obtained, but in mixture with inseparable impurities. Once again, an acidic cocatalyst was inefficient (Entry 12), but extending the reaction time somewhat improved the results (Entry 13). To finish with, 1-acetylindolin-3-ones are also known to add to enals under secondary amine catalysis. ${ }^{22}$ Our standard reaction conditions applied to substrate $\mathbf{6 h}$ delivered the expected fused pentacyclic product 7 ha as an inseparable mixture of diastereomers in good yield and enantioselectivities, which could even be improved by using $\mathrm{CH}_{2} \mathrm{Cl}_{2}$ as solvent (Entries 15 and 16).

\subsection{Alternative bis-nucleophilic units}

The last direction we wanted to explore for the Type I products was the possibility to replace the pyrrole ring by other nucleophilic units. Disappointingly, our initial attempts with indole derivatives failed to provide the expected products. ${ }^{9 a} \mathrm{We}$ wanted to re-investigate their use and turned our attention towards more electron-rich $\mathrm{N}$-(2-aminoethyl)indole derivative 8 (Scheme 6). When it was added to the reaction mixture after an initial organocatalytic Michael addition between 1a and 2a, the expected indolopiperazine $\mathbf{9}$ was obtained as its pure trans diastereomer in $32 \%$ yield and $85 \%$ ee after purification by flash chromatography on silica gel. Alternatively, a purification of the crude reaction mixture on neutral alumina delivered the corresponding 1,4-dihydropyridine $\mathbf{1 0}$ in 30\% yield and $91 \%$ ee. This last result demonstrates that the Pictet-Spengler cyclization with the indole derivative is not spontaneous in the reaction conditions and requires an acidic environment, thus highlighting the unique behavior of the pyrrole ring in its ability to cyclize in acid-free conditions.

In a complementary fashion, we were interested in using heteroatom-based pendant nucleophiles instead of an electronrich heteroaromatic ring. ${ }^{23}$ tert-Butyl acetoacetate (1a) and cinnamaldehyde (2a) were combined with five different bisnucleophiles 11a-c,12ain the presence of Hayashi-Jørgensen catalyst 4 (Table 2). No product formation was observed with 2-aminoethanol (11a) and anthranilamide (11b) (Entries 1 and 2). ${ }^{24}$ Conversely, the use of 2 -aminobenzyl alcohol (11c) delivered the moderately pure expected product $13 \mathrm{c}$ in modest amount but with a fair enantioselectivity (Entry 3). At last, using 2-aminophenol (12a) resulted in a mixture of a small amount of expected 14 together with its regioisomer 15 (Entry 5). ${ }^{25}$ This result was all the more interesting since, contrary to products 13c and 14, the new 1,2,3,4-tetrahydropyridine 15 Type II product bearing three contiguous stereogenic centers was formed virtually as a single diastereomer and also with excellent enantioselectivity. This discovery paved the way for further developments towards the enantioselective synthesis of this uncommon heterocyclic motif, which will be discussed in details in the following section. 
Table 2. Screening of heteroatomic bis-nucleophiles for the enantioselective multicomponent synthesis of tetrahydropyridines. [a]
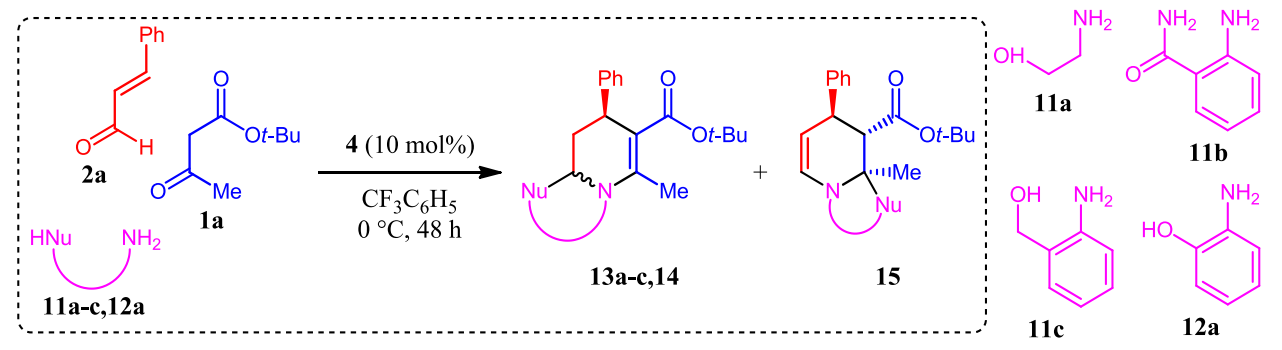

\begin{tabular}{|c|c|c|c|c|c|}
\hline \multirow{2}{*}{ Entry } & \multirow{2}{*}{$\begin{array}{c}\text { Bis- } \\
\text { nucleophile }\end{array}$} & \multicolumn{2}{|c|}{ Product 13a-c,14 } & \multicolumn{2}{|c|}{ Product 15} \\
\hline & & Yield $(d r)^{[\mathrm{b}]}$ & $e e^{[\mathrm{c}]}$ & Yield $(d r)^{[\mathrm{b}]}$ & $e e^{[\mathrm{c}]}$ \\
\hline 1 & 11a & 13a: no product & - & - & - \\
\hline 2 & 11b & 13b: no product & - & - & - \\
\hline 3 & 11c & 13c: $\sim 25 \%(1.3: 1 d r)$ & $88 \%$ and $90 \%$ & - & - \\
\hline 4 & 12a & 14: $<10 \%(1.5: 1 d r)^{[\mathrm{d}]}$ & n.d. & 15: $25 \%(>20: 1 d r)$ & $94 \%$ \\
\hline
\end{tabular}

aAll reactions were run using 1a $(0.200 \mathrm{mmol}, 1$ equiv), 2a $(0.300 \mathrm{mmol}, 1.5$ equiv), 11a-c,12a $(0.200 \mathrm{mmol}, 1$ equiv) and catalyst 4 (0.020 mmol, 0.1 equiv) in $\mathrm{CF}_{3} \mathrm{C}_{6} \mathrm{H}_{5}(2.5 \mathrm{~mL})$ for $48 \mathrm{~h}$ at $0{ }^{\circ} \mathrm{C}$. bYields of analytically pure isolated products and diastereomeric ratios $(d r)$ determined

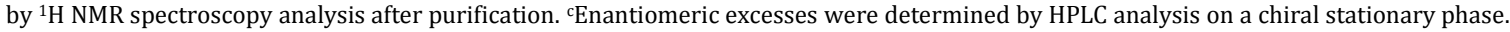
dThe product could not be obtained pure.

\section{Type II Products: 1,2,3,4-Tetrahydropyridines}

Having observed the formation of Type II product 15 (Table 2), we became interested in trying to fully counterbalance the regioselectivity of the multicomponent reaction to obtain this previously unknown family of 1,2,3,4-tetrahydropyridines, exclusively. We hypothesized that the equilibrium between iminium ions $\mathbf{F}$ and $\mathbf{F}^{\prime}$ and the relative stabilities of products $\mathbf{G}$ and $\mathbf{G}^{\prime}$ (Scheme 1) would be key factors to reach this goal. The usual higher stability of $\mathbf{F}$ and $\mathbf{G}$ over $\mathbf{F}^{\prime}$ and $\mathbf{G}^{\prime}$, respectively, can be explained by the higher delocalization of $\pi$ electrons through the enaminoester. We hypothesized that replacing the ester group by a bulkier tertiary amide would create strong 1,3-allylic strain, which could outcompete the stabilization energy brought about by the conjugation, thereby forcing the amide group to turn outside of the plane. ${ }^{20,26}$ Pleasingly, when tert-butyl acetoacetate (1a) was replaced by the corresponding Weinreb $\beta$-ketoamide 6d, only 1,2,3,4-tetrahydropyridine 16a was obtained in modest yield, as a single diastereomer (Scheme 7). Thereafter, a thorough optimization of the reaction conditions was conducted pointing

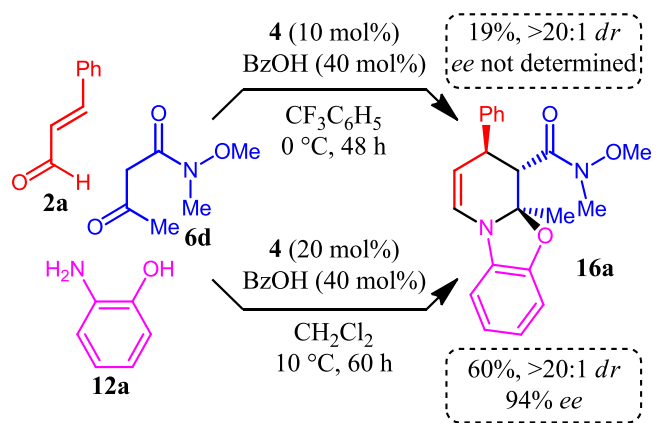

Scheme 7. 1,2,3,4-Tetrahydropyridines: control of regio- and stereoselectivity with Weinreb $\beta$-ketoamide $\mathbf{6 d}$. $^{10}$ towards: (i) an increase of the catalyst loading to $20 \mathrm{~mol} \%$; (ii) the use of benzoic acid as co-catalyst; (iii) the replacement of trifluorotoluene by $\mathrm{CH}_{2} \mathrm{Cl}_{2}$; (iv) the increase of the temperature to $10^{\circ} \mathrm{C}$ and of the reaction time to $60 \mathrm{~h} .{ }^{10}$ This new reaction was then exemplified on a variety of cinnamaldehyde derivatives 2 and functionalized 2-aminophenols 12 (Scheme 8). Products 16, in which four new bonds and three stereogenic centers are installed in a single synthetic operation were obtained with moderate yields, but high stereoselectivities. Variations on the $\beta$ ketoamide were less straightforward since

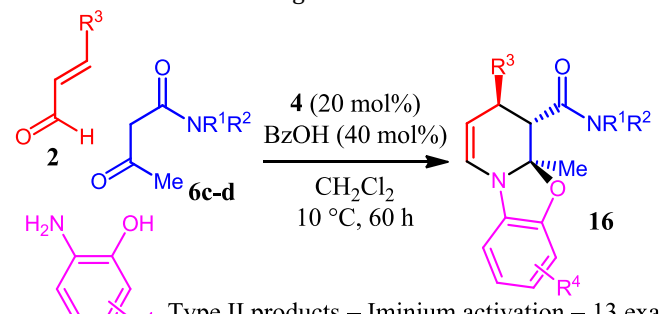

$\mathrm{R}^{4}$ Type II products - Iminium activation - 13 examples

12 4 new bonds: $29-60 \%$ yield

3 stereogenic carbon atoms: $>20: 1 d r, 82-96 \%$ ee

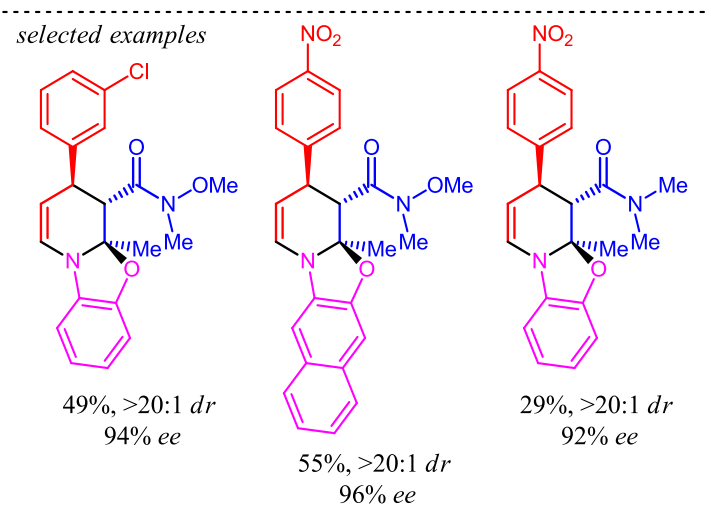

Scheme 8. 1,2,3,4-Tetrahydropyridines: previous results. ${ }^{10}$ 
the replacement of Weinreb amide $6 \mathbf{d}$ by the less activated $N, N$ dimethyl analogue $\mathbf{6 c}$ delivered the expected product with lower yield but preserved stereoselectivities. After our initial studies, we foresaw two different directions to increase the synthetic usefulness of this transformation (Scheme 9):

(i) Is it possible to replace the methyl group on the ketone by other substituents?

(ii) Are the different functionalities of the product (enamine aminal and amide) amenable to post-functionalization to reach more diversified scaffolds?

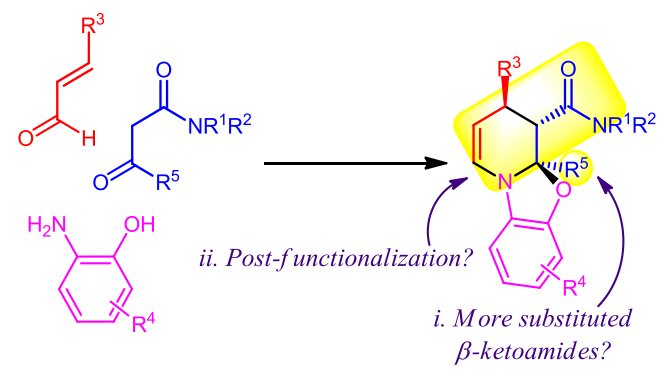

Scheme 9. 1,2,3,4-Tetrahydropyridines: open questions.

\subsection{Use of more diverse $\beta$-ketoamides}

At first, we screened $\gamma$-alkyl- and $\gamma$-aryl- $\beta$-ketoamides 17a-d, which we had used in our organocatalytic Michael addition to nitroolefins, ${ }^{20 a}$ in the standard reaction conditions to prepare the corresponding 1,2,3,4-tetrahydropyridines (Figure 2). Unfortunately, all of them proved to be not reactive enough and the expected products where obtained with less than $15 \%$ yields. To try to overcome this issue, $\gamma$-bromo-ketoamide $\mathbf{1 7 d}$ was prepared ${ }^{27}$ with the hope that the inductive withdrawing effect of the bromine atom would render the activation of the $\beta$ ketoamide easier. Moreover, it could also serve as a handle for post-functionalization. However, once again, only low conversion into the 1,2,3,4-tetrahydropyridine was observed.

$$
\overbrace{17 \mathbf{P}}^{\mathrm{Me}}
$$

Figure 2. Unsuitable $\beta$-ketoamide substrates 17a-d.

The only other option left was to modify the amide moiety, by replacing the $N$-methoxy- $N$-methyl unit by a group with stronger electron-withdrawing ability and/or that could provide a better interaction with the catalyst. Following the work of Jørgensen and co-workers on the Michael addition of 1,3-dicarbonyls bearing an oxazolidinone to nitroolefins, ${ }^{28}$ we turned our attention towards the use of the pyrrolidinone derivative 20. It was easily prepared by the thermal decomposition of 2,2,6trimethyl-4H-1,3-dioxin-4-one 18, followed by the trapping of the intermediate $\alpha$-oxoketene by pyrrolidinone 19.29 This new substrate was then exposed to the standard conditions for the multicomponent synthesis of 1,2,3,4-tetrahydropyridines, resulting in a complex mixture including regioisomeric products 21 and 22. From this result, we can see that it seems to be a balance between reactivity and regioselectivity as $\beta$-dicarbonyl compounds with a more acidic $\alpha$ position are more easily activated in the catalytic conditions but also tend to provide the 1,4,5,6-tetrahydropyridine regioisomer.

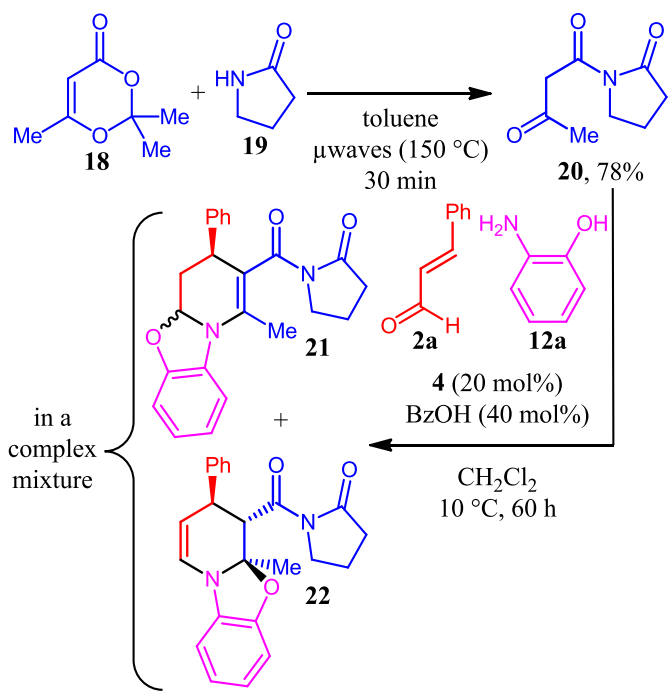

Scheme 10. Pyrrolidinone-derived $\beta$-ketoamide 20: synthesis and use in the multicomponent reaction.

\subsection{Post-functionalization on the products}

The major structural originality of 1,2,3,4-tetrahydropyridines compared to the products obtained in other methodologies targeting enantioenriched polyhydropyridines, is the presence of the enamine function. In our previous studies, we showed that both its reduction with dihydrogen in the presence of a catalytic amount of $\mathrm{Pd} / \mathrm{C}$ and its isomerization into the corresponding iminium ion under $\mathrm{Sc}(\mathrm{OTf})_{3}$-catalysis and the subsequent trapping with a potassium alcynyltrifluoroborate proceeded with good yields and good preservation of the enantiomeric excesses. ${ }^{10}$. To study the reactivity on other positions of the product, the reduction was repeated on enamine 16a to furnish 23(Scheme 11). In the presence of scandium (III) triflate as a
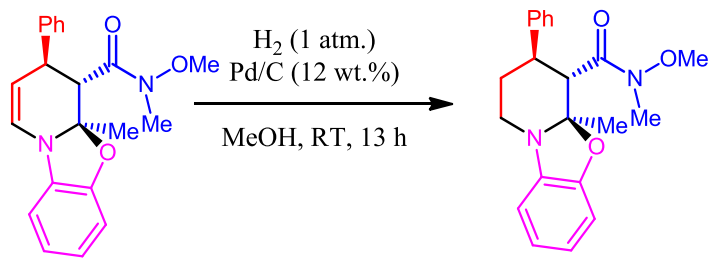

16a

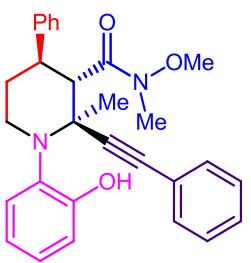

$\mathrm{KF}_{3} \mathrm{~B}$

23, $81 \%$

$25,42 \%,>20: 1 d r$

Scheme 11. Sequential post-functionalization of $1,2,3,4-$ tetrahydropyridines 16a 
catalytic Lewis acid, potassium phenylethynyltrifluoroborate (24) could then add to the transient iminium ion obtained by the opening of aminal $\mathbf{2 3}$ to furnish compound $\mathbf{2 5}$ in moderate yield but as a single diastereomer. ${ }^{30}$ Unfortunately, all attempts to have the Weinreb amide functionalities of $\mathbf{1 6 a}, 23$ or 25 being reduced by treatment with metal hydrides did not meet with success, since either no conversion or extensive degradation was observed.

Another possibility to valorize the 1,2,3,4-tetrahydropyridines is to combine two multicomponent reactions sequentially to attain extremely high molecular complexity in a very short synthetic sequence. ${ }^{31}$ The three-component reaction of enamines with insitu generated 2 -azadienes has been known as the Povarov reaction. ${ }^{32}$ Combining enamine 16a with ethyl glyoxylate (26) and $p$-toluidine (27) in the presence of a catalytic amount of $\mathrm{Sc}(\mathrm{OTf})_{3}$ triggered the cycloaddition process to afford the expected product $\mathbf{2 8}$ in good yield (Scheme 12). Pleasingly, the two new stereogenic centers at the ring junction were installed in a cis relationship with complete diastereoselectivity. On the opposite, there was no control of the stereogenic center $\alpha$ to the ester functionality, presumably because the intermediate imine was formed as a mixture of $(E)$ and $(Z)$ diastereomers. All in all, the enantioenriched fused pentacyclic scaffold $\mathbf{2 8}$ has been elaborated in only two steps from five very simple starting materials.

\subsection{Attempts of four-component reaction}

Having post-functionalized the enamine moiety of 1,2,3,4tetrahydropyridines with potassium organotrifluoroborate $\mathbf{2 4}$, we also became intrigued by the possibility to integrate it directly in the multicomponent reaction (Table 3).

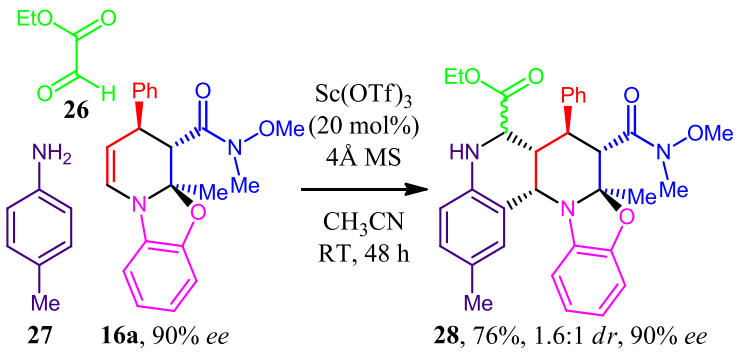

Scheme 12. Post-functionalization of 1,2,3,4-tetrahydropyridine 16 a by a Povarov reaction.

4-Fluorocinnamaldehyde $\mathbf{2 f}$ was selected as Michael acceptor to allow an easy identification of three- and four-component products $\mathbf{2 9}$ and $\mathbf{3 0}$ by ${ }^{19} \mathrm{~F}$ NMR in the potentially complex crude reaction mixture. ${ }^{33}$ At first, we could show that potassium phenylethynyltrifluoroborate $\mathbf{2 4}$ does not interfere with the initial organocatalytic process since three-component product 29 was formed in 82\% NMR yield but four-component product 30 could not be observed in the crude reaction mixture (Entry 1). ${ }^{34}$ Lewis acids were then evaluated as co-catalysts to help in the tautomerization process required to generate and trap the iminium ion. The development of such a transformation would represent a unique dually-catalyzed four-component reaction. ${ }^{35}$ $\mathrm{Sc}(\mathrm{OTf})_{3}$ had only a limited influence since it decreased the yield of $\mathbf{2 9}$ but did not trigger the formation of $\mathbf{3 0}$ (Entry 2). On the contrary, with $\mathrm{ZrCl}_{4}$ and $\mathrm{NbCl}_{5}$, small amounts ( 20\% yields) of four-component product $\mathbf{3 0}$ could be observed, unfortunately as racemic mixtures (Entries 3 and 4). The replacement of the Lewis acid with a Rh complex was also inefficient (Entry 5).

Table 3. Attempts of synthesis of tetrasubstituted piperidines by a dually-catalyzed four-component reaction. [a]

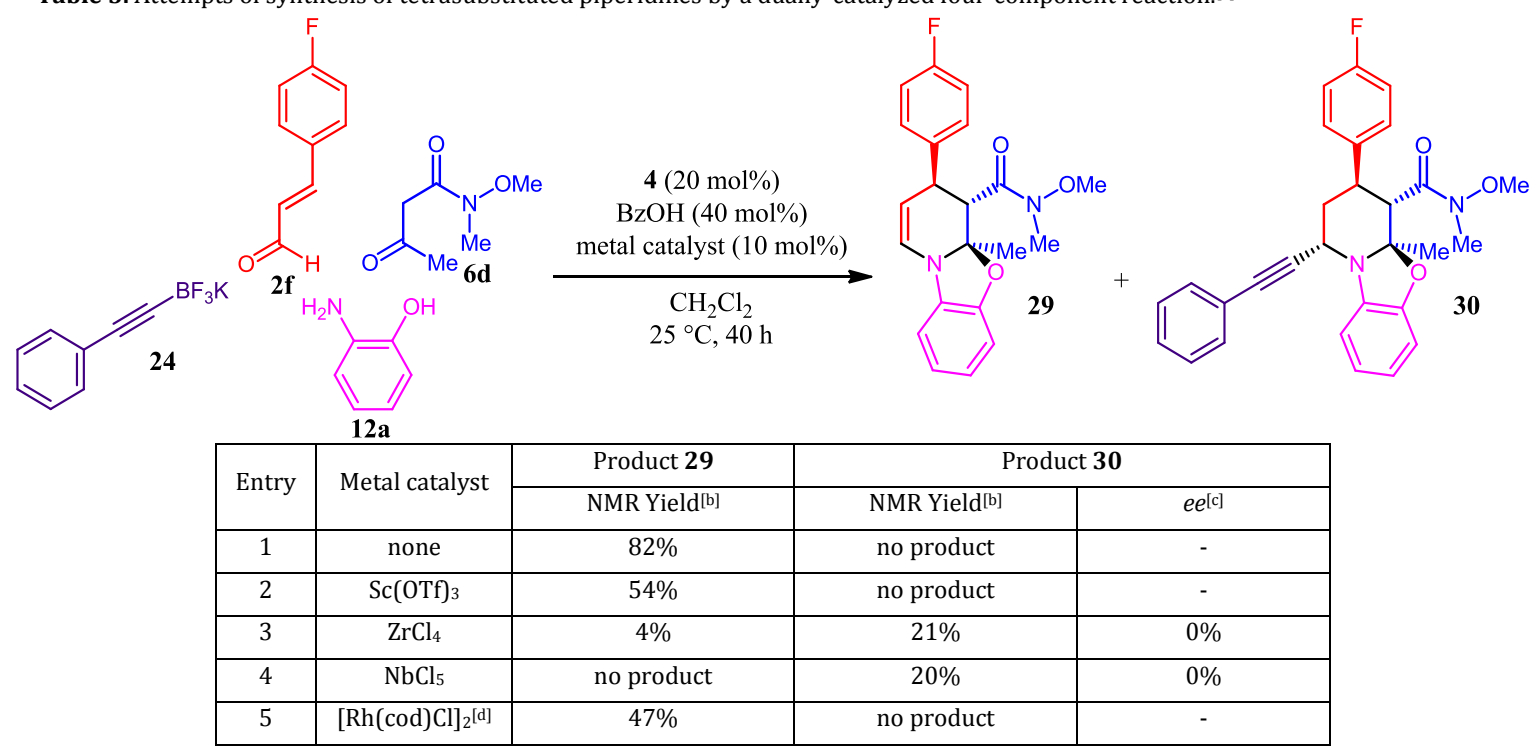

aAll reactions were run using $\mathbf{6 d}(0.200 \mathrm{mmol}, 1$ equiv), $\mathbf{2 f}(0.300 \mathrm{mmol}, 1.5$ equiv), 12a ( $0.200 \mathrm{mmol}, 1$ equiv), 23 ( $0.300 \mathrm{mmol}, 1.5$ equiv), catalyst $4\left(0.020 \mathrm{mmol}, 0.1\right.$ equiv) $\mathrm{PhCO}_{2} \mathrm{H}(0.040 \mathrm{mmol}, 0.2$ equiv $)$ and the metal catalyst $(0.010 \mathrm{mmol}, 10 \mathrm{~mol} \%)$ in $\mathrm{CH}_{2} \mathrm{Cl}_{2}(2.5 \mathrm{~mL})$ for 40 $\mathrm{h}$ at $25^{\circ} \mathrm{C}$. bNMR yields of products 29 and $\mathbf{3 0}$ were determined by ${ }^{19} \mathrm{~F}$ NMR spectroscopy analysis of the crude reaction mixture. ${ }^{\circ}$ Enantiomeric excesses were determined by HPLC analysis on a chiral stationary phase. $\mathrm{d} 5 \mathrm{~mol} \%$ of metal catalyst were used. 


\section{Type III Products: Bridged Perhydropyridines (2,6-DABCOs)}

A careful study of the structure of 1,2,3,4-tetrahydropyridines presented in the previous section highlights the presence of the enamine moiety that could interconvert with the corresponding iminium ion and of an inert tertiary amide. Replacing the latter one by a secondary amide would add another nucleophilic position and a cyclization onto the electrophilic iminium ion could be envisioned, delivering bridged perhydropyridines as Type III products (Scheme 1). Relying on our studies on the addition of cyclic secondary $\beta$-ketoamides to $\alpha, \beta$-unsaturated ketones and aldehydes under bifunctional hydrogen-bonding organocatalysis, ${ }^{36,37}$ we studied the possibility to add a bisnucleophilic species to these reaction conditions. Pleasingly, mixing cyclic secondary $\beta$-ketoamides $\mathbf{3 1}$ with acrolein (32) and aminophenols 12 in the presence of bifunctional thiourea catalyst $\mathbf{3 3}^{38}$ delivered chemoselectively bridged perhydropyridines 34 (Scheme 13).11a Because of their resemblance with $\mathrm{DABCO}$, but with the nitrogen atoms not located on the bridgehead positions, we decided to call these compounds 2,6-DABCOs
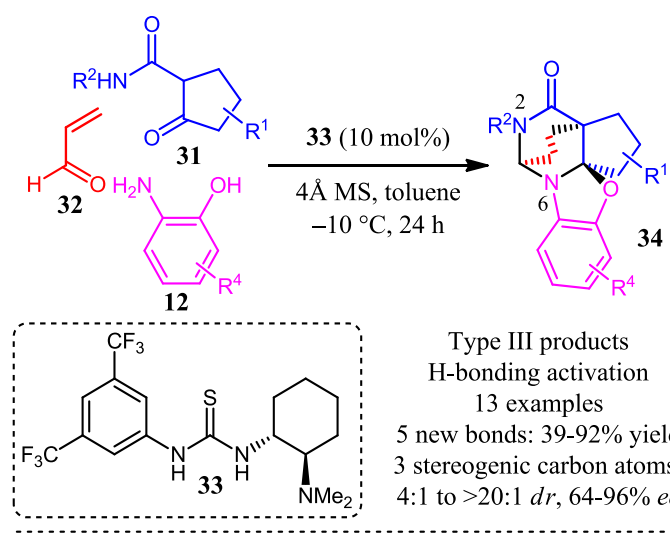

Type III products H-bonding activation

13 examples 5 new bonds: $39-92 \%$ yield 3 stereogenic carbon atoms: $4: 1$ to $>20: 1 d r, 64-96 \%$ ee
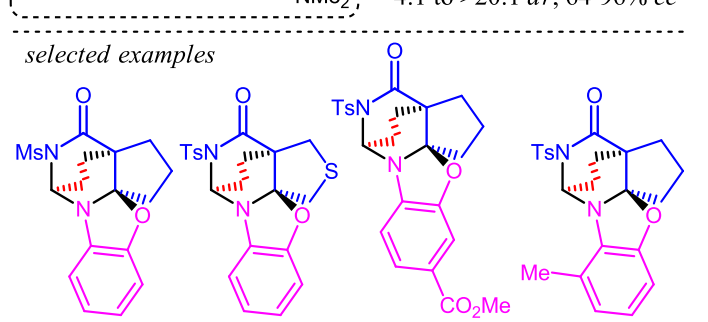

$\begin{array}{cccc}70 \%,>20: 1 d r & 65 \%, 11: 1 d r & 80 \%,>20: 1 d r & 72 \%,>20: 1 d r \\ 90 \% \text { ee } & 84 \% \text { ee } & 96 \% \text { ee } & 64 \% \text { ee }\end{array}$

Scheme 13. Bridged perhydropyridines (2,6-DABCOs): previous results. $11 \mathrm{a}$

During the development of this transformation, we also uncovered the following important parameters for its success:

(i) A strongly electron-withdrawing group is required on the $\beta$-ketoamide's nitrogen atom, such as a sulfonyl group, to ensure both productivity and enantioselectivity. In addition to this, the reaction with acyclic pronucleophiles is poorly enantioselective. (ii) The structure of the aminophenols has a strong influence on the enantioselectivity of the reaction. Moreover, they are the only suitable bis-nucleophiles as free or monoprotected phenylene diamine resulted in complete degradation, whereas 2-aminobenzyl alcohol (11c) or salicylic acid yielded to trace amounts of the desired products.

(iii) Other enals than acrolein (32) perform very poorly in the multicomponent reaction: low yield of product was obtained with methacrolein, while crotonaldehyde delivered virtually racemic product.

(iv) $\quad 4 \AA \AA$ molecular sieves are required to attain high levels of enantioselectivity, presumably by trapping the water produced during the course of the reaction.

In view of the intriguing structure of these products, but also the limitations is terms of substrate diversity revealed by the scope study, we deemed it interesting to proceed to more detailed studies in the following directions (Scheme 14):

(i) Could $\beta$-substituted enals participate in this transformations, possibility by modifying the other substrates and the mode of activation of the organocatalyst?

(ii) Can we envisage to get rid of the phenol moiety on the aniline, to replace the final iminium ion trapping by a tautomerization into the corresponding enamine?

(iii) Could the synthetic potential of the reaction be increased by taking advantage of the reactivities of the aminal functionalities?

(iv) Is it possible to cleave the sulfonyl group on the product, whose presence on the $\beta$-ketoamide substrate is essential for the success of the transformation?

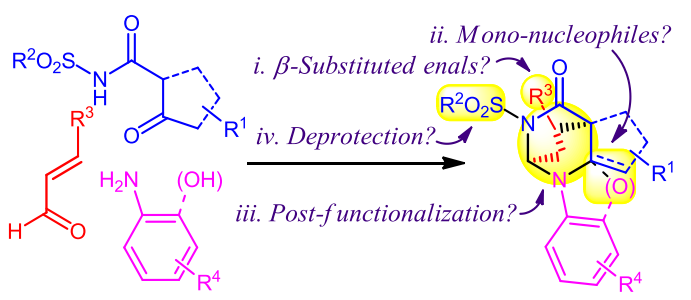

Scheme 14. Bridged perhydropyridines (2,6-DABCOs): open questions.

\subsection{Introduction of $\beta$-substituted enals}

Given the results obtained for the preparation of Type II products from $\alpha$-methylene tertiary $\beta$-ketoamides and cinnamaldehyde derivatives with a secondary amine as catalyst (Scheme 8), we hypothesized that applying the very same reaction conditions to the corresponding secondary amides might be an interesting entry to expand the substrate scope of 2,6-DABCO synthesis (Scheme 15). More specifically, acyclic $N$ tosyl secondary $\beta$-ketoamide $\mathbf{3 5}$ could be introduced directly in the reaction conditions used to prepare the Type II products, resulting in the production of the expected 2,6-DABCOs 36a-c with high diastereoselectivities but only moderate enantiomeric excesses. ${ }^{39}$ 


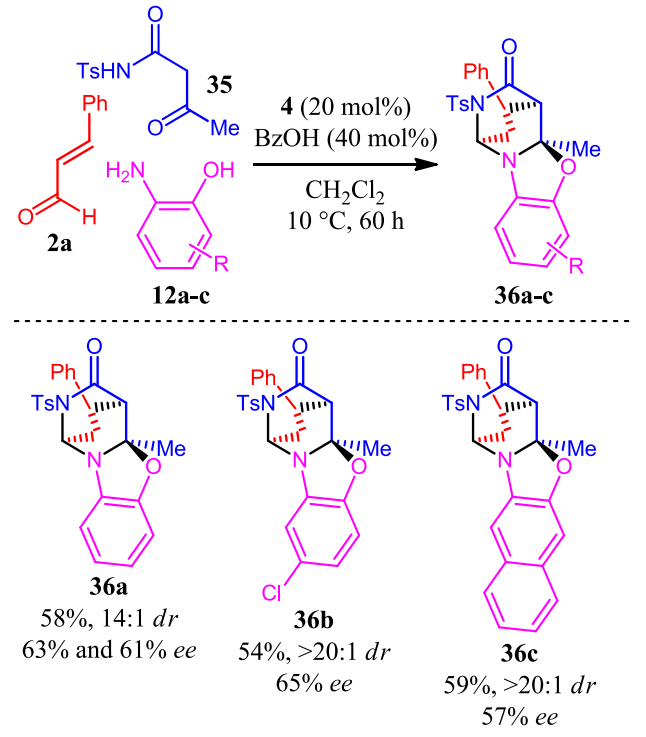

Scheme 15. Synthesis of 2,6-DABCOs under iminium ion activation.

\subsection{Tautomerization into the enamine}

Initially, the aromatic hydroxyl functionality appeared as an essential structural feature to observe the formation of the 2,6DABCO products. In subsequent studies, we wanted to investigate what is happening in its absence, especially whether the iminium ion J could tautomerize into a stable tetrasubstituted enamine $\mathbf{K}$, when no nucleophile is present to trap it (Scheme 16). The presence of an additional substituent ( $R$ ) on the enamine might be useful to increase its stability.

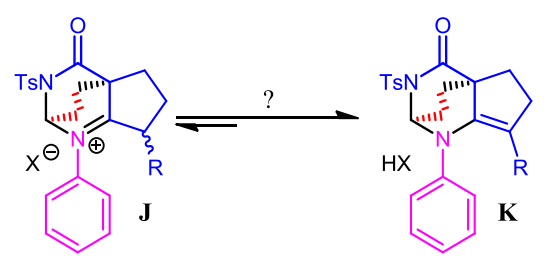

Scheme 16. Working hypothesis for the tautomerization of the iminium ion $\mathbf{J}$ into the enamine $\mathbf{K}$.

To test this hypothesis, we needed at first to be able to prepare the corresponding $\gamma$-substituted $\beta$-ketoamides, which had never been described in the literature before and represent a real synthetic challenge because of their sensibility to a variety of acidic or basic reaction conditions. The $\gamma$-alkylation of substrate 31a would require the intermediate preparation of a tris-anion before adding an alkylating agent, 4-fluorobenzyl bromide (37), which would react with the least stabilized anion (Scheme 17). Unfortunately, all our attempts to obtain product $\mathbf{3 8}$ failed because of competing $\alpha$-alkylation and degradation processes. An alternative pathway would go through a $\gamma$-aldolizationcrotonization sequence followed by the reduction of the carboncarbon double bond. ${ }^{40}$ Alkenylation of $\mathbf{3 1 a}$ with 4chlorobenzaldehyde (39) proceeded efficiently and stereoselectively but attempts to reduce enone $\mathbf{4 0}$ into $\mathbf{4 1}$ either by catalytic hydrogenation or conjugate hydride addition resulted into complex reaction mixtures. Fortunately, $\gamma$ functionalization could eventually be attained by the bromination of 31a in classical conditions, with compound $\mathbf{4 2}$ being obtained as a 1:1 mixture of diastereomers.

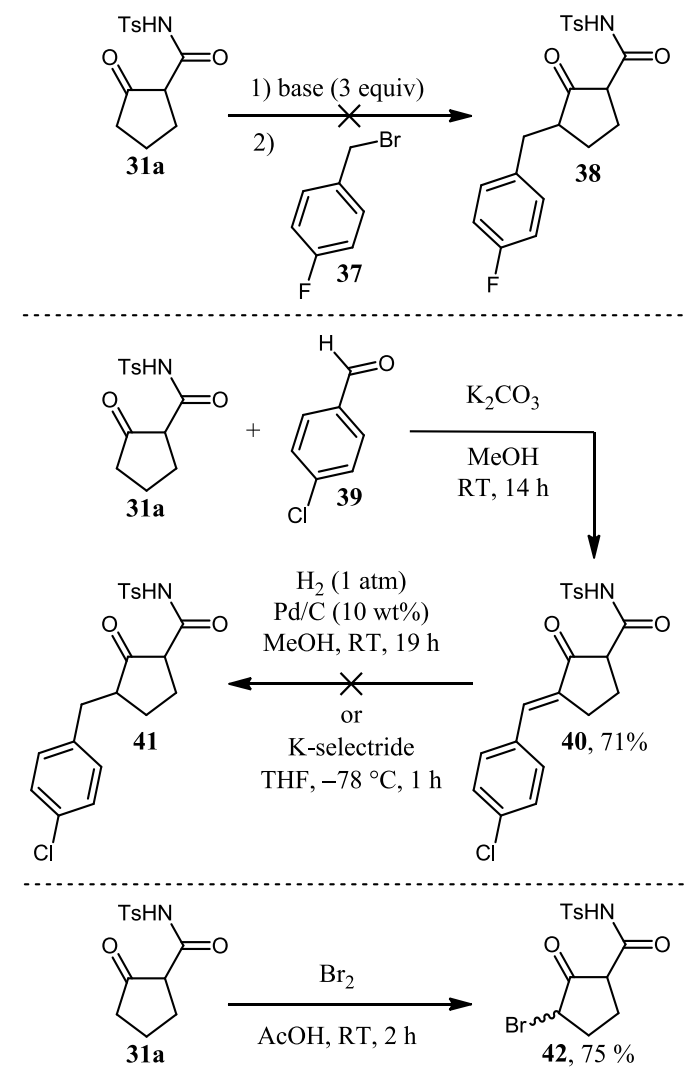

Scheme 17. Preparation of $\gamma$-substituted $\beta$-ketoamides.

Substrate 42 was then evaluated in the multicomponent enantioselective synthesis of 2,6-DABCOs (Scheme 18). At first, aniline (43) was tested as the third reaction partner in the reaction with $\mathbf{4 2}$ to try to obtain enamine product $\mathbf{4 4}$ Unfortunately the bromine atom did not seem to bring enough stability to the enamine and a complete degradation of the reaction mixture was observed. On the opposite, $\gamma$-bromo- $\beta$ ketoamide revealed itself as a potent pronucleophile in the traditional 2,6-DABCO synthesis with 2-aminophenol (12a). In this case, product $\mathbf{4 5}$ was obtained in $50 \%$ yield as a single diastereomer and with $39 \%$ ee. ${ }^{41}$ Even though, this level of enantioselectivity is not high enough in a synthetic context, it indicates that kinetic resolution can occur to some extent during the multicomponent organocatalytic process. In addition to this, when $\gamma, \delta$-unsaturated $\beta$-ketoamide $\mathbf{4 0}$ was placed in the reaction conditions, no 2,6-DABCO product could be observed (not depicted). 


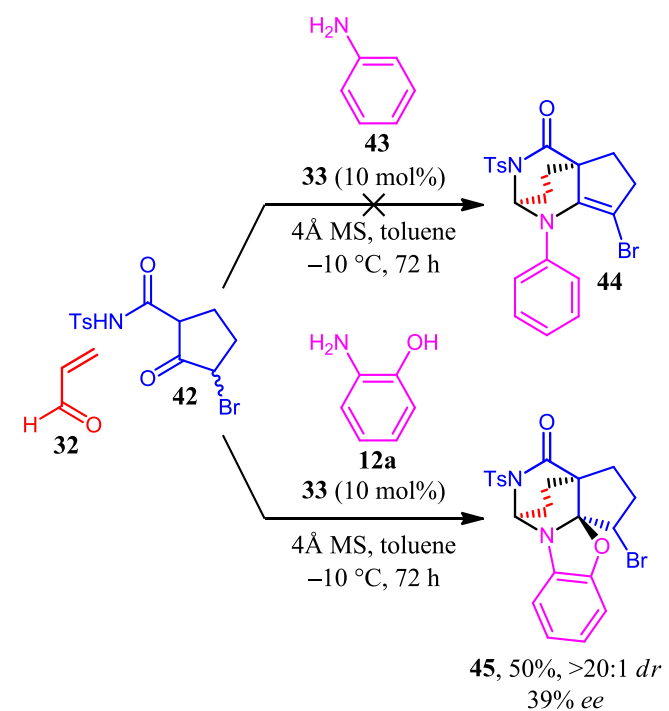

Scheme 18. Synthesis of 2,6-DABCO from $\gamma$-bromo- $\beta$-ketoamide 42.

\subsection{Post-functionalization of the products}

In our seminal publication, ${ }^{11 a}$ we had shown that the $\mathrm{N}, \mathrm{O}$-aminal functionality of the 2,6-DABCO could be re-opened in the presence of a Lewis acid such as boron trifluoride etherate and the resulting iminium ion could be trapped with a potassium alkynyltrifluoroborate. We repeated those reaction conditions by combining 34a and $\mathbf{2 4}$ to verify that the enantiopurity of the product is maintained during this post-functionalization (Scheme 19). Pleasingly, the addition product $\mathbf{4 6}$ was isolated in $59 \%$ yield with only a minor erosion of the enantiomeric excess from $94 \%$ to $86 \%$.

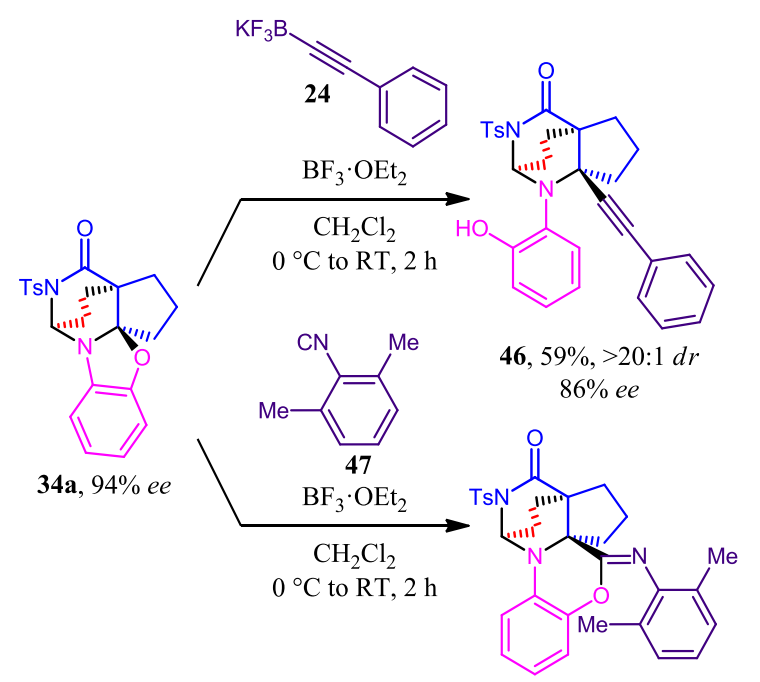

48, $79 \%,>20: 1 d r$ $94 \%$ ee
Other nucleophiles were also evaluated to intercept the transient iminium ion. Neither allyltrimethylsilane nor hydride sources such as triethylsilane, sodium borohydride or Hantzsch ester showed reactivity. On the contrary, complete degradation of the starting material was observed with trimethylsilyl cyanide. We also hypothesized that it would be possible to perform an insertion reaction in the $\mathrm{C}-\mathrm{O}$ bond of the $\mathrm{N}, \mathrm{O}$-aminal. Indeed, the reaction of $\mathbf{3 4 a}$ with (2,6-dimethylphenyl)isocyanide (47) afforded imidate $\mathbf{4 8}$ with good yield and complete retention of the stereochemical information. Because isocyanides are among the most popular partners in multicomponent reactions, ${ }^{42}$ an attempt was made to introduce $\mathbf{4 7}$ directly in the reaction conditions used to produce the 2,6-DABCOs. Unfortunately, it behaved only as a spectator since no four-component coupling could be found but instead the reaction proceeded as usual to furnish the three-component product.

\subsection{Cleavage of the sulfonyl group}

To finish our study, we wanted to explore the possibility to cleave the sulfonyl group on the 2,6-DABCO products. Indeed, this group is absolutely required to obtain high yields and stereoselectivities and being able to remove it would significantly expand the synthetic potential of the method. Unfortunately, applying classical deprotection conditions for a tosyl group on the nitrogen atom of an amide (either sodium naphthalenide or TBAF) to 34a resulted in the complete degradation of the starting material. Surmising that the labile $\mathrm{N}, \mathrm{O}$-aminal was responsible for this failure, the first deprotection conditions were attempted again on compound 46 (Scheme 20). This time, the cleavage occurred smoothly and deprotected 2,6-DABCO 49 could be isolated in $48 \%$ yield without any change in the enantiomeric excess. A solution to circumvent the problems encountered during the deprotection could be to replace the tosyl group by a 4-nosyl unit, which could be cleaved in milder reaction conditions.

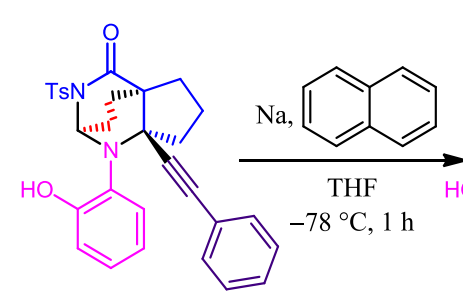

46, $86 \%$ ee

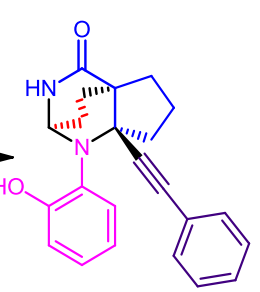

49, $48 \%$ $86 \%$ ee
Scheme 20. Deprotection of the tosyl group.

Moreover, the corresponding $N$-nosyl- $\beta$-ketoamides such as $\mathbf{5 0}$ had already been used in an independent study to access enantioenriched glutarimides by coupling them with $\alpha, \beta$ unsaturated acyl cyanides. ${ }^{36 e}$ Notably, the stronger electronwithdrawing effect of the 4-nosyl group also had a positive influence on the stereoselectivity of the reaction. When $\mathbf{5 0}$ was placed in the standard reaction conditions, the expected 2,6DABCO $\mathbf{5 1}$ was formed in good yield and very high diastereoselectivity but with only $59 \%$ ee (Scheme 23). This low enantioselectivity combined with issues of solubility and stability of the product led us to abandon this direction.

Scheme 19. Post-functionalization of 2,6-DABCO 34a. 


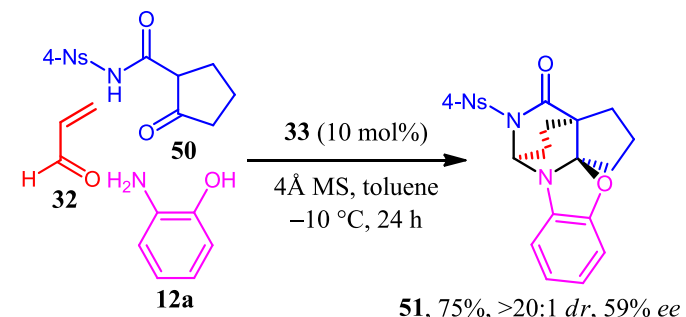

Scheme 21. Synthesis of $N$-(4-nosyl)-2,6-DABCO 51

\section{Conclusion and Perspective}

As a conclusion, in this Feature Article, we have thoroughly discussed all our recent work on the enantioselective preparation of nitrogen-containing six-membered heterocycles from very simple starting materials by the introduction of organocatalysts in multicomponent reactions. The general reaction scheme proceeds from a Michael donor, a Michael acceptor and a third component containing a primary amine, which will be able to cross-link the diverse carbonyl functionalities present on the two other partners after the initial

Table 4. General summary of reactions parameters for the three families of organocatalytic enantioselective multicomponent reactions ( $v$ = suitable and efficient; $-=$ moderately efficient and/or selective; $\otimes$ = not suitable).

\begin{tabular}{|c|c|c|c|}
\hline Family of products & 1,4,5,6-Tetrahydropyridines & 1,2,3,4-Tetrahydropyridines & Bridged Perhydropyridines \\
\hline Michael donor & $\begin{array}{l}\text { (v) } \begin{array}{l}\text { open-chain } \alpha \text {-methylene } \\
\beta \text {-ketoesters and diketones } \\
\text { cyclic diketones }\end{array} \\
-\begin{array}{l}\alpha \text {-methylene } \beta \text {-ketoamides } \\
\text { (reduced yields) }\end{array} \\
-\quad \begin{array}{l}\alpha \text {-methylene } \quad \beta \text {-keto- } \\
\text { thioesters (reduced } e e \text { ) }\end{array} \\
\text { v } 1 \text {-acetylindolin-3-ones }\end{array}$ & $\begin{array}{l}-\begin{array}{l}\text { open-chain } \alpha \text {-methylene } \\
\beta \text {-ketoesters (mixture) }\end{array} \\
\vee \quad \begin{array}{l}\text { open-chain } \alpha \text {-methylene } \\
\text { Weinreb } \beta \text {-ketoamides }\end{array} \\
\begin{array}{l}\text { open-chain } \alpha \text {-methylene } \beta \text { - } \\
\text { ketoamides } \quad \text { (reduced } \\
\text { yields) }\end{array}\end{array}$ & 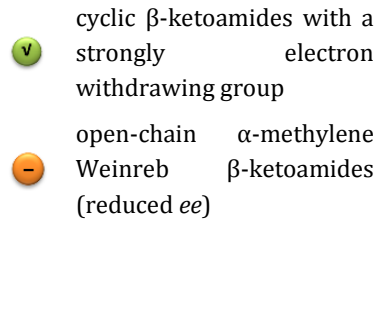 \\
\hline Michael acceptor & $\begin{array}{l}\text { (v)-arylenals } \\
-\begin{array}{l}\beta \text {-alkylenals (reduced } \\
\text { yields) }\end{array} \\
-\begin{array}{l}\text { ethyl 4-oxobut-2-enoate } \\
\text { (reduced yields) }\end{array}\end{array}$ & $\begin{array}{ll}\text { (v) } & \beta \text {-arylenals } \\
- & \begin{array}{l}\beta \text {-alkylenals } \\
\text { yields) }\end{array} \quad \text { (reduced }\end{array}$ & $\begin{array}{ll}\text { (v) } & \text { acrolein } \\
- & \begin{array}{l}\text { methacrolein } \\
\text { yield) }\end{array} \\
\times \quad \text { crotonaldehyde (racemic) } \\
-\quad \beta \text {-alkylenals (reduced } e e \text { ) }\end{array}$ \\
\hline Third component & 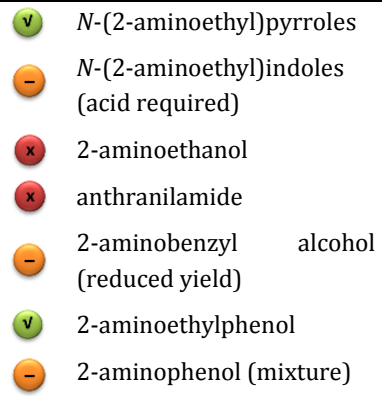 & (v) 2-aminophenols & $\begin{array}{l}\text { ( } 2 \text {-aminophenols } \\
\text { × phenylene diamine } \\
\text { × anthranilic acid }\end{array}$ \\
\hline Organocatalyst & $\begin{array}{l}\text { Iminium activation (catalyst 4). } \\
\text { Addition of } \mathrm{BzOH} \text { is sometimes } \\
\text { useful. }\end{array}$ & $\begin{array}{l}\text { Iminium activation (catalyst } 4 \text { ), in } \\
\text { the presence of } \mathrm{BzOH} \text { as co- } \\
\text { catalyst. }\end{array}$ & $\begin{array}{l}\text { Bifunctional hydrogen-bonding } \\
\text { (catalyst 34) for acrolein. } \\
\text { Iminium activation (catalyst 4) for } \\
\text { aromatic enals. }\end{array}$ \\
\hline Results & $\begin{array}{l}\text { v good yields } \\
\text { × no diastereoselectivities } \\
\text { v good enantioselectivities }\end{array}$ & $\begin{array}{l}\text { - moderate yields } \\
\text { v high diastereoselectivity } \\
\text { v good enantioselectivities }\end{array}$ & $\begin{array}{l}\text { v) good yields } \\
\text { v good diastereoselectivities } \\
-\begin{array}{l}\text { moderate to good } \\
\text { enantioselectivities }\end{array}\end{array}$ \\
\hline
\end{tabular}


enantioselective Michael addition. Three main families of product were obtained: 1,4,5,6-tetrahydropyridines, 1,2,3,4tetrahydropyridines and bridged perhydropyridines. The main required features of the substrates for each family of products, along with the subsequent choice of the suitable organocatalyst, are summarized in Table 4.

Beyond the potential interest of the present methods to prepare previously unknown polyheterocyclic scaffolds, we believe that the main input of our work is to provide pieces of evidence that organocatalysis, because of its high functional compatibility, can develop as a general and efficient tool to effect organic transformations in complex reaction media with excellent chemo- and stereoselectivities.

\section{Starting Materials}

- Unless specified, commercial reagents and solvents were used as received.

- Except the new substrates, which are described below, all $\beta$ ketoamides were prepared according to known literature procedures. ${ }^{11 a, 20 a, 29 b}$

- Acrolein and (E)-cinnamaldehyde were distilled just prior to use.

- Catalyst $\mathbf{4}$ was purchased from Sigma-Aldrich and catalyst $\mathbf{3 3}$ from Strem.

- Crushed $4 \AA ̊$ molecular sieves was stored in an oven at $110^{\circ} \mathrm{C}$.

- $\mathrm{BF}_{3} \cdot \mathrm{OEt}_{2}$ was refluxed on $\mathrm{CaH}_{2}$ and distilled prior to use.

- Potassium phenylethynyltrifluoroborate $\mathbf{2 4}$ was prepared according to known literature procedure. ${ }^{43}$

- $\mathrm{CH}_{2} \mathrm{Cl}_{2}$, THF and toluene were dried using a M-Braun SPS-800 system. Other solvents $\left(\alpha, \alpha, \alpha\right.$-trifluorotoluene, $\mathrm{CH}_{3} \mathrm{CN}, \mathrm{CHCl}_{3}$ $\mathrm{MeOH}$ and $\mathrm{AcOH}$ ) were purchased in anhydrous quality and used without further drying.

\section{Instrumentation and Analyse}

- Analytical thin layer chromatography (TLC) was performed on silica gel 60 F254 aluminum plates (Macherey-Nagel) containing a $254 \mathrm{~nm}$ fluorescent indicator. TLC plates were visualized by exposure to short wave ultraviolet light $(254 \mathrm{~nm})$ and to anisaldehyde $(2.5 \mathrm{~mL}$ of $p$-anisaldehyde, $3 \mathrm{~mL}$ of concentrated $\mathrm{H}_{2} \mathrm{SO}_{4}$ and $1.5 \mathrm{~mL}$ of $\mathrm{AcOH}$ in $100 \mathrm{~mL}$ of EtOH) or vanillin ( $2 \mathrm{~g}$ of vanillin and $4 \mathrm{~mL}$ of concentrated $\mathrm{H}_{2} \mathrm{SO}_{4}$ in $100 \mathrm{~mL}$ of EtOH) followed by heating.

- Flash column chromatography was performed using silica gel (35$70 \mu \mathrm{m}$, Acros or 35-70 $\mu \mathrm{m}$, Macherey-Nagel) and basic $\mathrm{Al}_{2} \mathrm{O}_{3}$ (Macherey-Nagel)

- Proton nuclear magnetic resonance $\left({ }^{1} \mathrm{H}\right.$ NMR) spectra were recorded with a Bruker AV 400 spectrometer. Proton chemical shifts are reported in parts per million ( $\delta$ scale), and are referenced using residual protium in the NMR solvent $\left(\mathrm{CDCl}_{3}: \delta 7.26\left(\mathrm{CHCl}_{3}\right)\right.$ or $\mathrm{d}^{6}$-DMSO: $\delta 2.50\left(\mathrm{~d}^{5}\right.$-DMSO)). Data are reported as follows: chemical shift (multiplicity ( $\mathrm{s}=$ singlet, br $\mathrm{s}=$ broad singlet, $\mathrm{d}=$ doublet, $\mathrm{t}=$ triplet, $\mathrm{q}=$ quadruplet, quint $=$ quintuplet, sept $=$ septuplet, $\mathrm{m}=$ multiplet), coupling constant $(\mathrm{s})(\mathrm{Hz})$, integration).

- Carbon-13 nuclear magnetic resonance $\left({ }^{13} \mathrm{C}\right.$ NMR: CPD and DEPT135) spectra were recorded with Bruker AV 300 or AV 400 spectrometers. Carbon chemical shifts are reported in parts per million ( $\delta$ scale), and are referenced using the carbon resonances of the solvent ( $\delta 77.16\left(\mathrm{CHCl}_{3}\right)$ or $\mathrm{d}^{6}$-DMSO: $\delta 39.53\left(\mathrm{~d}^{6}\right.$-DMSO)) Data are reported as follows: chemical shift $\left(\mathrm{CH}_{\mathrm{n}}\right.$ where $\mathrm{n}$ is the number of hydrogen atoms linked to the carbon atom).

- Fluorine-19 nuclear magnetic resonance ( ${ }^{19} \mathrm{~F}$ NMR) spectra were recorded with Bruker an AV 400 spectrometer. Fluorine chemical shifts are reported in parts per million ( $\delta$ scale), and are referenced using 4-fluorobenzene as an added internal standard $(\delta-113.15)$.
- $\quad$ High resolution mass spectra (HRMS) were recorded on a Waters Synapt G2 HDMS apparatus using a positive electrospray (ESI) ionization source.

- $\quad$ HPLC analyses for the determination of enantiomeric excesses were performed on a Merck-Hitachi system equipped with Chiralcel OD-3, Chiralpak AD-H, Chiralpak AZ-H, Chiralpak IA, Chiralpak IB, Chiralpak IC, Chiralpak ID, Chiralpak IE, Chiralpak IF, Lux-Amylose- 2 and Lux-Cellulose- 4 columns.

- Optical Rotations were recorded on a Perkin Elmer 241 Polarimeter or an Anton Paar MCP 200 Polarimeter at $589 \mathrm{~nm}$ and $25{ }^{\circ} \mathrm{C}$. Specific rotations are reported as follows: specific rotation (concentration in grams $/ 100 \mathrm{~mL}$ of solution, solvent).

\section{Procedures}

General procedure A for the three-component synthesis of pyrrolopiperazines 5 and $7 \mathrm{aa}-\mathrm{ha}, 7 \mathrm{ad}, 7 \mathrm{fe}$, and tetrahydropyridines 13c and 15: A reaction tube was charged with $(S)-(-)-\alpha, \alpha-d i p h e n y l-2$ pyrrolidinemethanol trimethylsilyl ether (4) $(6.6 \mathrm{mg}, 0.020 \mathrm{mmol}, 0.1$ equiv), dry $\alpha, \alpha, \alpha$-trifluorotoluene $(2.5 \mathrm{~mL})$, flushed with argon and placed at $0{ }^{\circ}$. $\beta$-ketoester $\mathbf{1}(0.200 \mathrm{mmol}, 1$ equiv) was then added followed by freshly distilled $(E)$ - $\alpha, \beta$-unsaturated aldehyde $2(0.300 \mathrm{mmol}, 1.5$ equiv) and $\mathrm{N}$-(2-aminoethyl)pyrrole $\mathbf{3}$ or substituted aniline 11c,12 $(0.200$ mmol, 1 equiv). After 2 days, the solution was directly purified by flash column chromatography on silica gel to provide the pyrrolopiperazines $\mathbf{5}$ generally as two separable diastereomers or the tetrahydropyridines 13c or 15. For the description of products 5 (Scheme 2), see reference 9a.

General procedure $B$ for the three-component synthesis of 1,2,3,4 tetrahydropyridines 16 and 2,6-DABCOs 36a-c: In a reaction tube, $\beta$ ketoamide $\mathbf{6 c - d , 3 5}$ ( $0.2 \mathrm{mmol}, 1$ equiv), $(E)$-cinnamaldehyde derivative 2 ( $0.3 \mathrm{mmol}, 1.5$ equiv), functionalized 2 -aminophenol $16(0.2 \mathrm{mmol}$ 1equiv) and benzoic acid ( $0.08 \mathrm{mmol}, 0.4$ equiv) were dissolved in dry $\mathrm{CH}_{2} \mathrm{Cl}_{2}(2 \mathrm{~mL})$ under argon and placed at $10{ }^{\circ} \mathrm{C}$. Then, $(S)-(-)-\alpha, \alpha-$ diphenyl-2-pyrrolidinemethanol trimethylsilyl ether (4) $(0.04 \mathrm{mmol}, 0.2$ equiv) was added to the mixture. After $60 \mathrm{~h}$, around ten drops of $\mathrm{NH}_{4} \mathrm{Cl}$ were added to the reaction mixture to deactivate the catalyst. The organic layer was then separated and concentrated under vacuum. The diastereomeric ratio of the crude product was determined by ${ }^{1} \mathrm{H}$ NMR Purification by flash chromatography over silica gel yielded the corresponding three-component product. For the description of products 16 (Schemes 7 and 8), see reference 10 .

General procedure $C$ for the three-component synthesis of 2,6 DABCOs 34, 45 and 51: Crushed $4 \AA$ molecular sieves $(200 \mathrm{mg})$ was placed in a $25-\mathrm{mL}$ reaction tube equipped with a septum. Air was evacuated under high vacuum and the reaction flask heated by means of a heat gun. After coming back to room temperature, the reaction flask was filled with argon. This operation was repeated a second time. $(R, R)$ Takemoto catalyst $33(8.3 \mathrm{mg}, 0.020 \mathrm{mmol}, 0.1$ equiv), $\beta$-ketoamide 31 ( $0.200 \mathrm{mmol}, 1$ equiv) and functionalized aminophenol $12(0.300 \mathrm{mmol}$ 1.5 equiv) were introduced in the reaction flask, which was once again flushed with argon. Dry toluene $(6 \mathrm{~mL})$ was added and the reaction flask was cooled to $-10{ }^{\circ} \mathrm{C}$. After 10 minutes, acrolein (32) $(0.400 \mathrm{mmol}, 2$ equiv) was added via syringe and the reaction mixture was stirred at -10 ${ }^{\circ} \mathrm{C}$ for $24 \mathrm{~h}$. It was then filtered over a short pad of silica gel $(2 \mathrm{~cm})$ that was washed with EtOAc $(50 \mathrm{~mL})$. Concentration under reduced pressure afforded a solid that was purified by flash column chromatography on silica gel $\left(\mathrm{CH}_{2} \mathrm{Cl}_{2} / \mathrm{EtOAc}\right)$ to provide the pure 2,6-DABCO 34. For the description of products 34 (Scheme 13), see reference 11a.

(10R)-9-tert-butyl 10-ethyl 8-methyl-6,10,11,11a-tetrahydro-5Hpyrido[1,2-a]pyrrolo [2,1-c]pyrazine-9,10-dicarboxylate (5c). A reaction tube was charged with $(S)-(-)-\alpha, \alpha$-diphenyl-2pyrrolidinemethanol trimethylsilyl ether (4) $(6.6 \mathrm{mg}, 0.020 \mathrm{mmol}, 0.1$ equiv), benzoic acid (4.9 mg, $0.040 \mathrm{mmol}, 0.2$ equiv), dry $\alpha, \alpha, \alpha-$ trifluorotoluene $(2.5 \mathrm{~mL})$, flushed with argon and placed at $0{ }^{\circ} \mathrm{C}$. tert-Butyl acetoacetate (1a) $(31.6 \mathrm{mg}, 32.9 \mu \mathrm{L}, 0.200 \mathrm{mmol}, 1$ equiv) and ( $E$ )-ethyl 4oxobut-2-enoate (2c) $(30.8 \mathrm{mg}, 28.9 \mu \mathrm{L}, 0.240 \mathrm{mmol}, 1.2$ equiv) were then added. After full conversion of tert-butyl acetoacetate (1a) as monitored by TLC, followed by the addition of $N$-(2-aminoethyl)pyrrole (3a) $(22.0$ 
$\mathrm{mg}, 21.6 \mu \mathrm{L}, 0.200 \mathrm{mmol}, 1$ equiv), the mixture was stirred at $0{ }^{\circ} \mathrm{C}$ for another $24 \mathrm{~h}$. After reaction, direct purification by flash chromatography (PE/EtOAc 80:20) afforded $\mathbf{5 c}$ as a mixture of diastereomers as a yellow oil (32.4 mg, $0.090 \mathrm{mmol}, 45 \%$ yield, $\sim 1.2: 1 \mathrm{dr}, 94 \%$ and $93 \% e e$ ).

\section{TLC (PE/EtOAc 4:1) R $f 0.18$ (UV, vanillin).}

${ }^{1} \mathrm{H}$ NMR (400 MHz, $\left.\mathbf{C D C l}_{3}\right) \delta(\mathrm{ppm})$ cis-(10R,11aR)-diastereomer (minor): $6.55-6.53(\mathrm{~m}, 1 \mathrm{H}), 6.17(\mathrm{t}, J=3.2 \mathrm{~Hz}, 1 \mathrm{H}), 5.92-5.89(\mathrm{~m}, 1 \mathrm{H}), 4.41(\mathrm{dd}, J$ $=8.9,3.2 \mathrm{~Hz}, 1 \mathrm{H}), 4.23-4.09(\mathrm{~m}, 3 \mathrm{H}), 4.09-3.93(\mathrm{~m}, 2 \mathrm{H}), 3.67-3.62(\mathrm{~m}$ 1H), $3.40-3.31(\mathrm{~m}, 1 \mathrm{H}), 2.54-2.49(\mathrm{~m}, 1 \mathrm{H}), 2.49(\mathrm{~s}, 3 \mathrm{H}), 2.20-2.11(\mathrm{~m}$ $1 \mathrm{H}), 1.42(\mathrm{~s}, 9 \mathrm{H}), 1.19(\mathrm{t}, J=7.1 \mathrm{~Hz}, 3 \mathrm{H})$; trans-(10R,11aS)-diastereomer (major): $6.58-6.56(\mathrm{~m}, 1 \mathrm{H}), 6.13(\mathrm{t}, J=3.2 \mathrm{~Hz}, 1 \mathrm{H}), 5.96-5.93(\mathrm{~m}, 1 \mathrm{H})$ $4.36(\mathrm{dd}, J=11.5,3.2 \mathrm{~Hz}, 1 \mathrm{H}), 4.09-3.93(\mathrm{~m}, 5 \mathrm{H}), 3.71-3.67(\mathrm{~m}, 1 \mathrm{H}), 3.40$ - $3.31(\mathrm{~m}, 1 \mathrm{H}), 2.54-2.49(\mathrm{~m}, 1 \mathrm{H}), 2.46(\mathrm{~s}, 3 \mathrm{H}), 1.99-1.90(\mathrm{~m}, 1 \mathrm{H}), 1.44$ (s, 9H), $1.28(\mathrm{t}, J=7.1 \mathrm{~Hz}, 3 \mathrm{H})$.

${ }^{13}$ C NMR (101 MHz, $\left.\mathbf{C D C l}_{3}\right) \delta$ (ppm) cis-(10R,11aR)-diastereomer (minor): 175.3 (C), 167.6 (C), 153.7 (C), 128.8 (C), 119.0 (CH), 108.5 (CH), 103.5 (CH), $99.8(\mathrm{C}), 79.3(\mathrm{C}), 60.5\left(\mathrm{CH}_{2}\right), 52.9(\mathrm{CH}), 44.9\left(\mathrm{CH}_{2}\right), 44.2\left(\mathrm{CH}_{2}\right), 41.2$ (CH), $32.4\left(\mathrm{CH}_{2}\right), 28.4\left(3 \mathrm{CH}_{3}\right), 17.0\left(\mathrm{CH}_{3}\right), 14.2\left(\mathrm{CH}_{3}\right)$; trans-(10R,11aS)diastereomer (major): 175.8 (C), 168.1 (C), 153.3 (C), 129.3 (C), 118.9 $(\mathrm{CH}), 108.6(\mathrm{CH}), 103.1(\mathrm{CH}), 97.6(\mathrm{C}), 79.1(\mathrm{C}), 60.8\left(\mathrm{CH}_{2}\right), 50.8(\mathrm{CH}), 45.1$ $\left(\mathrm{CH}_{2}\right), 44.2\left(\mathrm{CH}_{2}\right), 39.6(\mathrm{CH}), 30.7\left(\mathrm{CH}_{2}\right), 28.5\left(3 \mathrm{CH}_{3}\right), 17.2\left(\mathrm{CH}_{3}\right), 14.5$ $\left(\mathrm{CH}_{3}\right)$

HRMS (ESI) calc'd for $\left[\mathrm{C}_{20} \mathrm{H}_{28} \mathrm{~N}_{2} \mathrm{O}_{4}+\mathrm{H}\right]^{+}: 361.2122$, found: 361.2119 .

HPLC cis-(10R,11aR)-diastereomer (minor): Chiralcel OD-3, Heptane/ethanol $90: 10,25^{\circ} \mathrm{C}, 1 \mathrm{ml} / \mathrm{min}, \lambda=254 \mathrm{~nm}, \tau_{\text {major }}=17.66 \mathrm{~min}$ $\tau_{\text {minor }}=10.93 \mathrm{~min}$; trans-(10R,11aS)-diastereomer (major): Chiralpak AD$\mathrm{H}$, Heptane/ethanol $90 / 10,25^{\circ} \mathrm{C}, 1 \mathrm{ml} / \mathrm{min}, \lambda=254 \mathrm{~nm}, \tau_{\text {major }}=6.90 \mathrm{~min}$, tminor $=10.82 \mathrm{~min}$.

1-(8-methyl-10-phenyl-6,10,11,11 $a$-tetrahydro-5H-pyrido[1,2-a] pyrrolo[2,1-c]pyrazin-9-yl)ethanone (7aa). Prepared according to the general procedure A using acetylacetone $(6 \mathbf{6 a})(20.0 \mathrm{mg}, 20.5 \mu \mathrm{L}, 0.200$ mmol, 1 equiv), (E)-cinnamaldehyde (2a) (39.7 mg, $37.8 \mu \mathrm{L}, 0.300 \mathrm{mmol}$, 1.5 equiv) and $N$-(2-aminoethyl)pyrrole (3a) $(22.0 \mathrm{mg}, 21.6 \mu \mathrm{L}, 0.200$ mmol, 1 equiv.), with the following modifications: dry $\mathrm{CH}_{2} \mathrm{Cl}_{2}(2.5 \mathrm{~mL})$ instead of $\alpha, \alpha, \alpha$-trifluorotoluene as solvent, benzoic acid $(4.9 \mathrm{mg}, 0.040$ mmol, 0.2 equiv) as co-catalyst and reaction run at $-10^{\circ} \mathrm{C}$ instead of $0{ }^{\circ} \mathrm{C}$ Purification by flash chromatography (PE/Et ${ }_{2} \mathrm{O} 33: 67$ ) afforded cis$(10 S, 11 \mathrm{a} R)-7 \mathrm{aa}$ as a pale solid $(27.5 \mathrm{mg}, 0.090 \mathrm{mmol}, 45 \%$ yield, $94 \% \mathrm{ee})$ and trans-(10S,11aS)-7aa as a pale yellow oil (14.0 mg, $0.046 \mathrm{mmol}, 23 \%$ yield, $90 \% e e$ ).

cis-(10S,11aR) diastereomer:

\section{TLC (PE/Et 20 1:2) Rf 0.36(UV, vanillin).}

${ }^{1} \mathbf{H}$ NMR (400 MHz, CDCl $) \delta(\mathrm{ppm}) 7.24-7.08(\mathrm{~m}, 5 \mathrm{H}), 6.51(\mathrm{~d}, J=1.8 \mathrm{~Hz}$ $1 \mathrm{H}), 6.05(\mathrm{dd}, J=3.4,2.8 \mathrm{~Hz}, 1 \mathrm{H}), 5.73(\mathrm{dt}, J=3.4,1.4 \mathrm{~Hz}, 1 \mathrm{H}), 4.54(\mathrm{dd}, J=$ 9.7, $3.0 \mathrm{~Hz}, 1 \mathrm{H}), 4.12-3.99(\mathrm{~m}, 4 \mathrm{H}), 3.37$ (ddd, $J=10.3,7.8,4.3 \mathrm{~Hz}, 1 \mathrm{H})$ 2.62 (ddd, $J=13.6,6.4,3.3 \mathrm{~Hz}, 1 \mathrm{H}), 2.45(\mathrm{~d}, J=1.0 \mathrm{~Hz}, 3 \mathrm{H}), 2.10-2.05(\mathrm{~m}$, $1 \mathrm{H}), 1.80(\mathrm{~s}, 3 \mathrm{H})$.

${ }^{13} \mathrm{C}$ NMR (101 MHz, CDCl $_{3}$ ) $\delta$ (ppm) 200.2 (C), 151.0 (C), 146.2 (C), 129.1 (C), $128.7(2 \mathrm{CH}), 127.2(2 \mathrm{CH}), 126.2(\mathrm{CH}), 118.6(\mathrm{CH}), 112.9(\mathrm{C}), 108.7$ (CH), $103.4(\mathrm{CH}), 53.6(\mathrm{CH}), 45.2\left(\mathrm{CH}_{2}\right), 44.0\left(\mathrm{CH}_{2}\right), 41.8(\mathrm{CH}), 40.7\left(\mathrm{CH}_{2}\right)$, $30.6\left(\mathrm{CH}_{3}\right), 17.1\left(\mathrm{CH}_{3}\right)$.

HRMS (ESI) calc'd for [ $\mathrm{C}_{20} \mathrm{H}_{22} \mathrm{~N}_{2} \mathrm{O}+\mathrm{H}^{+}$: 307.1805 , found: 307.1802 .

HPLC Lux-Amylose-2, Hexane/ethanol 80:20, $25^{\circ} \mathrm{C}, 1.0 \mathrm{~mL} / \mathrm{min}, \lambda=254$ $\mathrm{nm}, \tau_{\text {major }}=11.43 \mathrm{~min}, \tau_{\text {minor }}=9.02 \mathrm{~min}$.

$[\alpha]_{\mathbf{D}^{20}}=-4.7\left(\mathrm{c} 0.5, \mathrm{CHCl}_{3}\right)$.

\section{trans-(10S,11aS) diastereomer:}

TLC (PE/Et 20 1:2) Rf 0.33(UV, vanillin).

${ }^{1} \mathrm{H}$ NMR (400 MHz, $\left.\mathbf{C D C l}_{3}\right) \delta(\mathrm{ppm}) 7.35-7.27(\mathrm{~m}, 2 \mathrm{H}), 7.24-7.17(\mathrm{~m}$ $3 \mathrm{H}), 6.55(\mathrm{~d}, J=1.8 \mathrm{~Hz}, 1 \mathrm{H}), 6.11(\mathrm{t}, J=3.0 \mathrm{~Hz}, 1 \mathrm{H}), 5.80(\mathrm{dt}, J=3.5,1.2 \mathrm{~Hz}$ 1H), $4.19-4.07(\mathrm{~m}, 3 \mathrm{H}), 4.08-3.95(\mathrm{~m}, 2 \mathrm{H}), 3.42$ (ddd, $J=13.7,9.5,4.4$ $\mathrm{Hz}, 1 \mathrm{H}$ ), 2.61 (s, 3H), 2.43 (ddd, $J=13.0,3.5,2.8 \mathrm{~Hz}, 1 \mathrm{H}$ ), 2.18 (dd, $J=12.1$, $5.0 \mathrm{~Hz}, 1 \mathrm{H}), 2.00(\mathrm{~s}, 3 \mathrm{H})$.
${ }^{13}$ C NMR (101 MHz, CDCl 3 ) $\delta$ (ppm) 198.1 (C), 154.3 (C), 146.0 (C), 129.5 (C), $128.7(2 \mathrm{CH}), 128.1(2 \mathrm{CH}), 126.6(\mathrm{CH}), 118.9(\mathrm{CH}), 108.6(\mathrm{CH}), 107.8$ (C), $103.0(\mathrm{CH}), 49.5(\mathrm{CH}), 45.0\left(\mathrm{CH}_{2}\right), 44.5\left(\mathrm{CH}_{2}\right), 39.8(\mathrm{CH}), 36.3\left(\mathrm{CH}_{2}\right)$ $29.6\left(\mathrm{CH}_{3}\right), 18.0\left(\mathrm{CH}_{3}\right)$

HRMS (ESI) calc'd for $\left[\mathrm{C}_{20} \mathrm{H}_{22} \mathrm{~N}_{2} \mathrm{O}+\mathrm{H}\right]^{+}: 307.1805$, found: 307.1801 .

HPLC Lux-Amylose-2, Hexane/ethanol 90:10, $25^{\circ} \mathrm{C}, 1.0 \mathrm{~mL} / \mathrm{min}, \lambda=254$ $\mathrm{nm}, \tau_{\text {major }}=22,68 \mathrm{~min}, \tau_{\text {minor }}=18,58 \mathrm{~min}$.

$[\boldsymbol{\alpha}]_{\mathrm{D}}{ }^{20}=-9.9\left(\mathrm{c} 0.3, \mathrm{CHCl}_{3}\right)$.

1-(10-(4-chlorophenyl)-8-methyl-6,10,11,11a-tetrahydro-5Hpyrido[1,2-a]pyrrolo[2,1-c]pyrazin-9-yl)ethanone (7ad). Prepared according to the general procedure A using acetylacetone $(\mathbf{6 a})(20.0 \mathrm{mg}$ $20.5 \mu \mathrm{L}, 0.200 \mathrm{mmol}, 1$ equiv), (E)-4-chlorocinnamaldehyde (2d) $(50.0$ $\mathrm{mg}, 0.300 \mathrm{mmol}, 1.5$ equiv) and $N$-(2-aminoethyl)pyrrole (3a) $(22.0 \mathrm{mg}$ $21.6 \mu \mathrm{L}, 0.200 \mathrm{mmol}, 1$ equiv.), with the following modifications: dry $\mathrm{CH}_{2} \mathrm{Cl}_{2}(2.5 \mathrm{~mL})$ instead of $\alpha, \alpha, \alpha$-trifluorotoluene as solvent, benzoic acid ( $4.9 \mathrm{mg}, 0.040 \mathrm{mmol}, 0.2$ equiv) as co-catalyst and reaction run at $-10^{\circ} \mathrm{C}$ instead of $0{ }^{\circ} \mathrm{C}$. Purification by flash chromatography (PE/ $\mathrm{Et}_{2} \mathrm{O} 33: 67$ ) afforded cis- $(10 S, 11 \mathrm{a} R)-7$ ad as a pale solid $(25.8 \mathrm{mg}, 0.076 \mathrm{mmol}, 38 \%$ yield, $91 \% e e)$ and trans-(10S,11aS)-7ad as a pale yellow oil $(19.8 \mathrm{mg}$, $0.058 \mathrm{mmol}, 29 \%$ yield, $91 \% e e$ ).

\section{cis-(10S,11aR) diastereomer:}

TLC (PE/EtOAc 1:2) R $f 0.36$ (UV, vanillin)

${ }^{1} \mathrm{H}$ NMR (400 MHz, $\left.\mathbf{C D C l}_{3}\right) \delta(\mathrm{ppm}) 7.16(\mathrm{~d}, J=8.4 \mathrm{~Hz}, 2 \mathrm{H}), 7.03(\mathrm{~d}, J=8.4$ $\mathrm{Hz}, 2 \mathrm{H}), 6.53-6.46(\mathrm{~m}, 1 \mathrm{H}), 6.03(\mathrm{dd}, J=3.4,2.8 \mathrm{~Hz}, 1 \mathrm{H}), 5.65(\mathrm{dt}, J=3.4$ $1.3 \mathrm{~Hz}, 1 \mathrm{H}), 4.55$ (dd, $J=9.0,3.3 \mathrm{~Hz}, 1 \mathrm{H}), 4.13-4.06(\mathrm{~m}, 2 \mathrm{H}), 4.03-3.95$ $(\mathrm{m}, 2 \mathrm{H}), 3.43-3.31(\mathrm{~m}, 1 \mathrm{H}), 2.58(\mathrm{ddd}, J=13.6,6.4,3.6 \mathrm{~Hz}, 1 \mathrm{H}), 2.46(\mathrm{~d}, J$ $=0.9 \mathrm{~Hz}, 3 \mathrm{H}), 2.13-2.03(\mathrm{~m}, 1 \mathrm{H}), 1.82(\mathrm{~s}, 3 \mathrm{H})$.

${ }^{13} \mathrm{C}$ NMR (101 MHz, CDCl $) \delta(\mathrm{ppm}) 199.6$ (C), 151.6 (C), 144.7 (C), 131.8 (C), $128.76(2 \mathrm{CH}), 128.72(2 \mathrm{C}), 128.5(2 \mathrm{CH}), 118.6(\mathrm{CH}), 112.1(\mathrm{C}), 108.7$ $(\mathrm{CH}), 103.4(\mathrm{CH}), 53.4(\mathrm{CH}), 45.1\left(\mathrm{CH}_{2}\right), 44.2\left(\mathrm{CH}_{2}\right), 41.0(\mathrm{CH}), 39.9\left(\mathrm{CH}_{2}\right)$, $30.5\left(\mathrm{CH}_{3}\right), 17.2\left(\mathrm{CH}_{3}\right)$.

HRMS (ESI) calc'd for [ $\left.\mathrm{C}_{20} \mathrm{H}_{21} \mathrm{~N}_{2} \mathrm{OCl}+\mathrm{H}\right]^{+}: 341.1415$, found: 341.1414 .

HPLC Chiralpak AD-H, Hexane/ethanol 80:20, $25^{\circ} \mathrm{C}, 1.0 \mathrm{~mL} / \mathrm{min}, \lambda=254$ $\mathrm{nm}, \tau_{\text {major }}=8.34 \mathrm{~min}, \tau_{\text {minor }}=9.90 \mathrm{~min}$

$[\boldsymbol{\alpha}]_{\mathbf{D}}{ }^{20}=-3.3\left(\mathrm{c} 0.9, \mathrm{CHCl}_{3}\right)$.

trans-(10S,11aS) diastereomer:

TLC (PE/EtOAc 1:2) R $f$ 0.33(UV, vanillin).

${ }^{1} \mathrm{H}$ NMR (400 MHz, $\left.\mathrm{CDCl}_{3}\right) \delta(\mathrm{ppm}) 7.36-7.24(\mathrm{~m}, 2 \mathrm{H}), 7.17-7.13(\mathrm{~m}$ $2 \mathrm{H}), 6.61-6.55(\mathrm{~m}, 1 \mathrm{H}), 6.14(\mathrm{dd}, J=3.4,2.8 \mathrm{~Hz}, 1 \mathrm{H}), 5.85-5.79(\mathrm{dt}, J=$ $3.4,1.4 \mathrm{~Hz}, 1 \mathrm{H}), 4.18(\mathrm{dt}, J=13.5,3.8 \mathrm{~Hz}, 1 \mathrm{H}), 4.14-3.98(\mathrm{~m}, 4 \mathrm{H}), 3.44$ (ddd, $J=13.7,9.1,4.7 \mathrm{~Hz}, 1 \mathrm{H}$ ), $2.61(\mathrm{~s}, 3 \mathrm{H}), 2.44-2.38(\mathrm{~m}, 1 \mathrm{H}), 2.18$ (ddd, $J=13.1,12.0,5.0 \mathrm{~Hz}, 1 \mathrm{H}), 2.01(\mathrm{~s}, 3 \mathrm{H})$.

${ }^{13}$ C NMR (101 MHz, CDCl 3 ) $\delta$ (ppm) 197.7 (C), 154.5 (C), 144.5 (C), 132.4 (C), $129.5(2 \mathrm{CH}), 129.2(\mathrm{C}), 128.9(2 \mathrm{CH}), 119.0(\mathrm{CH}), 108.6(\mathrm{CH}), 107.5$ (C), $103.1(\mathrm{CH}), 49.4(\mathrm{CH}), 44.9\left(\mathrm{CH}_{2}\right), 44.5\left(\mathrm{CH}_{2}\right), 39.3(\mathrm{CH}), 36.2\left(\mathrm{CH}_{2}\right)$, $29.6\left(\mathrm{CH}_{3}\right), 18.0\left(\mathrm{CH}_{3}\right)$.

HRMS (ESI) calc'd for [ $\left.\mathrm{C}_{20} \mathrm{H}_{21} \mathrm{~N}_{2} \mathrm{OCl}+\mathrm{H}\right]^{+}: 341.1415$, found: 341.1411.

HPLC Lux-Amylose-2, Hexane/ethanol 80:20, $25^{\circ} \mathrm{C}, 1.0 \mathrm{~mL} / \mathrm{min}, \lambda=254$ $\mathrm{nm}, \tau_{\text {major }}=13.32 \mathrm{~min}, \tau_{\text {minor }}=10.93 \mathrm{~min}$.

$[\alpha]_{\mathrm{D}^{20}}=+2.5\left(\mathrm{c} 0.7, \mathrm{CHCl}_{3}\right)$.

(10S,11aS)- $N, N, 8$-trimethyl-10-phenyl-6,10,11,11a-tetrahydro-5Hpyrido[1,2-a]pyrrolo[2,1-c]pyrazine-9-carboxamide (7ca). Prepared according to the general procedure A using $N, N$-dimethyl-3oxobutanamide (6c) $(25.8 \mathrm{mg}, 0.200 \mathrm{mmol}, 1$ equiv), $(E)$-cinnamaldehyde (2a) $39.7 \mathrm{mg}, 37.8 \mu \mathrm{L}, 0.300 \mathrm{mmol}, 1.5$ equiv), $N$-(2-aminoethyl)pyrrole (3a) $(22.0 \mathrm{mg}, 21.6 \mu \mathrm{L}, 0.200 \mathrm{mmol}, 1$ equiv). Purification by flash chromatography $\left(\mathrm{CH}_{2} \mathrm{Cl}_{2} / \mathrm{MeOH} 98: 2\right.$ then $\left.\mathrm{CH}_{2} \mathrm{Cl}_{2} / \mathrm{MeOH} / \mathrm{AcOH} 98: 2: 0.5\right)$ afforded trans-(10S,11aS)-7ca as a yellow oil $(16.8 \mathrm{mg}, 0.050 \mathrm{mmol}, 25 \%$ yield, $92 \% e e$ ).

TLC $\left(\mathrm{CH}_{2} \mathrm{Cl}_{2} / \mathrm{MeOH} 50: 1\right)$ Rf 0.5 (UV, vanillin)

${ }^{1} \mathrm{H}$ NMR (400 MHz, $\left.\mathrm{CDCl}_{3}\right) \delta(\mathrm{ppm}) 7.29-7.16(\mathrm{~m}, 4 \mathrm{H}), 7.12-7.08(\mathrm{~m}$ $1 \mathrm{H}), 6.49-6.44(\mathrm{~m}, 1 \mathrm{H}), 6.05(\mathrm{t}, J=3.0 \mathrm{~Hz}, 1 \mathrm{H}), 5.74(\mathrm{~d}, \mathrm{~J}=2.7 \mathrm{~Hz}, 1 \mathrm{H})$, 
$4.16(\mathrm{~d}, J=7.3 \mathrm{~Hz}, 1 \mathrm{H}), 3.92(\mathrm{dtt}, J=11.4,8.2,3.5 \mathrm{~Hz}, 2 \mathrm{H}), 3.83-3.68(\mathrm{~m}$, 2H), 3.26 - 3.14 (m, 1H), 2.78 (s, 6H), $2.27-2.12(\mathrm{~m}, 2 \mathrm{H}), 1.87$ (s, 3H).

${ }^{13}$ C NMR (75 MHz, CDCl $\left._{3}\right) \delta(\mathrm{ppm}) 172.7$ (C), 145.1 (C), 139.3 (C), 130.3 (C), $128.5(2 \mathrm{CH}), 128.2(2 \mathrm{CH}), 126.4(\mathrm{CH}), 118.9(\mathrm{CH}), 108.4(\mathrm{CH}), 107.2$ (C), $102.4(\mathrm{CH}), 50.5(\mathrm{CH}), 45.2\left(\mathrm{CH}_{2}\right), 44.5\left(\mathrm{CH}_{2}\right), 39.5(\mathrm{CH}), 39.5\left(2 \mathrm{CH}_{3}\right)$, $35.3\left(\mathrm{CH}_{2}\right), 17.2\left(\mathrm{CH}_{3}\right)$.

HRMS (ESI) calc' d for $\left[\mathrm{C}_{21} \mathrm{H}_{25} \mathrm{~N}_{3} \mathrm{O}+\mathrm{H}\right]^{+}: 336.2070$, found: 336.2071 .

HPLC Lux-Cellulose-4, Hexane/ethanol 90:10, $25^{\circ} \mathrm{C}, 1.0 \mathrm{~mL} / \mathrm{min}, \lambda=254$ $\mathrm{nm}, \tau_{\text {major }}=26.36 \mathrm{~min}, \tau_{\text {minor }}=24.29 \mathrm{~min}$.

$[\alpha]_{\mathrm{D}}{ }^{20}=-24.6\left(\mathrm{c} 0.3, \mathrm{CHCl}_{3}\right)$.

(10S,11aS)- $N$-methoxy- $N, 8$-dimethyl-10-phenyl-6,10,11,11a-tetra hydro-5H-pyrido[1,2-a]pyrrolo[2,1-c]pyrazine-9-carboxamide

(7da). Prepared according to the general procedure A using $N$-methoxy$N$-methyl-3-oxobutanamide (6d) $(29.0 \mathrm{mg}, 0.200 \mathrm{mmol}, 1$ equiv), $(E)$ cinnamaldehyde (2a) $(39.7 \mathrm{mg}, 37.8 \mu \mathrm{L}, 0.300 \mathrm{mmol}, 1.5$ equiv), $N$-(2aminoethyl)pyrrole (3a) $(22.0 \mathrm{mg}, 21.6 \mu \mathrm{L}, 0.200 \mathrm{mmol}, 1$ equiv). Purification by flash chromatography $\left(\mathrm{CH}_{2} \mathrm{Cl}_{2} / \mathrm{MeOH}\right.$ 98:2 then $\mathrm{CH}_{2} \mathrm{Cl}_{2} / \mathrm{MeOH} / \mathrm{AcOH}$ 98:2:0.5) afforded trans-(10S,11aS)-7da as a yellow oil ( $19.7 \mathrm{mg}, 0.056 \mathrm{mmol}, 28 \%$ yield, $88 \% e e$ ).

TLC $\left(\mathrm{CH}_{2} \mathrm{Cl}_{2} / \mathrm{MeOH} 50: 1\right) \mathrm{R} f 0.36$ (UV, vanillin).

${ }^{1}$ H NMR (400 MHz, $\left.\mathbf{C D C l}_{3}\right) \delta(\mathrm{ppm}) 7.24-7.09(\mathrm{~m}, 5 \mathrm{H}), 6.46-6.42(\mathrm{~m}$, $1 \mathrm{H}), 6.02(\mathrm{t}, J=3.0 \mathrm{~Hz}, 1 \mathrm{H}), 5.72(\mathrm{~d}, J=2.9 \mathrm{~Hz}, 1 \mathrm{H}), 4.12(\mathrm{dd}, J=9.0,3.6 \mathrm{~Hz}$ $1 \mathrm{H}), 3.93-3.79(\mathrm{~m}, 4 \mathrm{H}), 3.29$ (s, 3H), $3.25-3.14(\mathrm{~m}, 1 \mathrm{H}), 2.95$ (s, 3H), 2.17 (dtt, $J=18.7,9.1,5.0 \mathrm{~Hz}, 2 \mathrm{H}), 1.95(\mathrm{~s}, 3 \mathrm{H})$.

${ }^{13}$ C NMR (75 MHz, CDCl 3 ) $\delta$ (ppm) 171.3 (C), 145.1 (C), 141.7 (C), 130.3 (C), $128.5(2 \mathrm{CH}), 128.3(2 \mathrm{CH}), 126.4(\mathrm{CH}), 118.9(\mathrm{CH}), 108.4(\mathrm{CH}), 106.4$ (C), $102.4(\mathrm{CH}), 60.8\left(\mathrm{CH}_{3}\right), 50.7(\mathrm{CH}), 44.9\left(\mathrm{CH}_{2}\right), 44.7\left(\mathrm{CH}_{2}\right), 38.6(\mathrm{CH})$, $35.2\left(\mathrm{CH}_{2}\right), 34.0\left(\mathrm{CH}_{3}\right), 17.3\left(\mathrm{CH}_{3}\right)$.

HRMS (ESI) calc'd for $\left[\mathrm{C}_{21} \mathrm{H}_{25} \mathrm{~N}_{3} \mathrm{O}_{2}+\mathrm{H}\right]^{+}: 352.2020$, found: 352.2021 .

HPLC Chiralpak AD-H, Hexane/EtOH 80:20, $25^{\circ} \mathrm{C}, 1.0 \mathrm{~mL} / \mathrm{min}, \lambda=254$ $\mathrm{nm}, \tau_{\text {major }}=10.21 \mathrm{~min}, \tau_{\text {minor }}=7.59 \mathrm{~min}$.

$[\alpha]_{\mathbf{D}^{20}}=-31.2\left(\mathrm{c} 0.2, \mathrm{CHCl}_{3}\right)$

Ethyl 8-methyl-10-phenyl-6,10,11,11a-tetrahydro-5H-pyrido[1,2-a] pyrrolo $[2,1-c]$ pyrazine-9-carbothioate (7ea). Prepared according to the general procedure A using $S$-ethyl acetothioacetate $(6 \mathbf{6 e})(29.2 \mathrm{mg}$, $26.8 \mu \mathrm{L} 0.200 \mathrm{mmol}, 1$ equiv), (E)-cinnamaldehyde (2a) $(39.7 \mathrm{mg}, 37.8 \mu \mathrm{L}$ $0.300 \mathrm{mmol}, 1.5$ equiv), $N$-(2-aminoethyl)pyrrole (3a) $(22.0 \mathrm{mg}, 21.6 \mu \mathrm{L}$, $0.200 \mathrm{mmol}, 1$ equiv). Purification by flash chromatography (PE/Et $\mathrm{H}_{2} \mathrm{O}$ 80:20 then PE/Et $20 / \mathrm{AcOH}$ 80:20: 0.5) afforded cis-(10S,11aR)-7ea as a yellow oil (15.0 mg, $0.042 \mathrm{mmol}, 21 \%$ yield, $49 \%$ ee) and trans$(10 S, 11 \mathrm{a} S)-7$ ea as a yellow oil $(23.2 \mathrm{mg}, 0.058 \mathrm{mmol}, 29 \%$ yield, $54 \% e e)$. cis-(10S,11aR) diastereomer:

TLC (PE/EtOAc 4:1) R $f 0.29$ (UV, vanillin).

${ }^{1}{ }^{H}$ NMR (400 MHz, $\left.\mathbf{C D C l}_{3}\right) \delta(\mathrm{ppm}) 7.19-7.13(\mathrm{~m}, 2 \mathrm{H}), 7.13-7.04(\mathrm{~m}$, $3 \mathrm{H}), 6.51-6.42(\mathrm{~m}, 1 \mathrm{H}), 5.99(\mathrm{dd}, J=3.5,2.8 \mathrm{~Hz}, 1 \mathrm{H}), 5.63(\mathrm{dt}, J=3.5,1.4$ $\mathrm{Hz}, 1 \mathrm{H}), 4.55(\mathrm{dd}, J=8.6,3.6 \mathrm{~Hz}, 1 \mathrm{H}), 4.26-4.18(\mathrm{~m}, 1 \mathrm{H}), 4.07(\mathrm{dt}, J=13.0$ $3.4 \mathrm{~Hz}, 1 \mathrm{H}), 4.03-3.97(\mathrm{~m}, 2 \mathrm{H}), 3.39$ (ddd, $J=13.5,8.9,5.2 \mathrm{~Hz}, 1 \mathrm{H}), 2.74-$ $2.57(\mathrm{~m}, 3 \mathrm{H}), 2.42(\mathrm{~d}, J=1.1 \mathrm{~Hz}, 3 \mathrm{H}), 2.19(\mathrm{dt}, J=13.6,8.8 \mathrm{~Hz}, 1 \mathrm{H}), 0.95(\mathrm{t}$, $J=7.4 \mathrm{~Hz}, 3 \mathrm{H})$.

${ }^{13}$ C NMR (101 MHz, CDCl $) \delta$ (ppm) 192.4 (C), 149.4 (C), 145.5 (C), 128.9 (C), $128.2(2 \mathrm{CH}), 127.5(2 \mathrm{CH}), 125.9(\mathrm{CH}), 118.5(\mathrm{CH}), 111.4(\mathrm{C}), 108.7$ (CH), $103.4(\mathrm{CH}), 53.5(\mathrm{CH}), 45.2\left(\mathrm{CH}_{2}\right), 44.4\left(\mathrm{CH}_{2}\right), 40.9(\mathrm{CH}), 39.5\left(\mathrm{CH}_{2}\right)$, $23.5\left(\mathrm{CH}_{2}\right), 17.4\left(\mathrm{CH}_{3}\right), 15.0\left(\mathrm{CH}_{3}\right)$.

HRMS (ESI) calc'd for [ $\left.\mathrm{C}_{21} \mathrm{H}_{24} \mathrm{~N}_{2} \mathrm{OS}+\mathrm{H}\right]^{+}: 353.1682$, found: 353.1681 .

HPLC Lux-Amylose-2, Hexane/ethanol 80:20, $25^{\circ} \mathrm{C}, 1.0 \mathrm{~mL} / \mathrm{min}, \lambda=254$ $\mathrm{nm}, \tau_{\text {major }}=7.15 \mathrm{~min}, \tau_{\text {minor }}=6.20 \mathrm{~min}$.

$[\alpha]_{\mathbf{D}^{20}}=-11.6\left(\mathrm{c} 0.2, \mathrm{CHCl}_{3}\right)$

trans-(10S,11aS) diastereomer:

TLC (PE/EtOAc 4:1) Rf 0.2 (UV, vanillin).

${ }^{1} \mathrm{H}$ NMR (400 MHz, $\left.\mathrm{CDCl}_{3}\right) \delta(\mathrm{ppm}) 7.34-7.29(\mathrm{~m}, 2 \mathrm{H}), 7.24-7.19(\mathrm{~m}$, $3 \mathrm{H}), 6.55(\mathrm{tt}, J=1.7,0.6 \mathrm{~Hz}, 1 \mathrm{H}), 6.12(\mathrm{dd}, J=3.6,2.7 \mathrm{~Hz}, 1 \mathrm{H}), 5.80(\mathrm{dt}, J=$
3.6, $1.4 \mathrm{~Hz}, 1 \mathrm{H}$ ), 4.37 (dd, $J=4.9,2.7 \mathrm{~Hz}, 1 \mathrm{H}), 4.21-4.10(\mathrm{~m}, 2 \mathrm{H}), 4.07-$ $3.99(\mathrm{~m}, 2 \mathrm{H}), 3.43$ (ddd, $J=13.8,9.6,4.4 \mathrm{~Hz}, 1 \mathrm{H}), 2.86-2.77(\mathrm{~m}, 1 \mathrm{H}), 2.67$ $(\mathrm{dt}, J=13.3,7.4 \mathrm{~Hz}, 1 \mathrm{H}), 2.60(\mathrm{~s}, 3 \mathrm{H}), 2.46(\mathrm{ddd}, J=13.1,4.0,2.7 \mathrm{~Hz}, 1 \mathrm{H})$ 2.17 (ddd, $J=13.1,12.0,4.8 \mathrm{~Hz}, 1 \mathrm{H}), 1.15(\mathrm{t}, J=7.4 \mathrm{~Hz}, 3 \mathrm{H}$ ).

${ }^{13}$ C NMR (101 MHz, CDCl $)$ ) $\delta$ (ppm) 190.2 (C), 152.5 (C), 145.6 (C), 129.4 (C), $128.5(2 \mathrm{CH}), 127.9(2 \mathrm{CH}), 126.4(\mathrm{CH}), 118.9(\mathrm{CH}), 108.6(\mathrm{CH}), 106.2$ (C), $103.0(\mathrm{CH}), 49.6(\mathrm{CH}), 44.9\left(\mathrm{CH}_{2}\right), 44.7\left(\mathrm{CH}_{2}\right), 38.6(\mathrm{CH}), 36.1\left(\mathrm{CH}_{2}\right)$ $23.5\left(\mathrm{CH}_{2}\right), 17.9\left(\mathrm{CH}_{3}\right), 15.1\left(\mathrm{CH}_{3}\right)$.

HRMS (ESI) calc'd for [ $\left.\mathrm{C}_{21} \mathrm{H}_{24} \mathrm{~N}_{2} \mathrm{OS}+\mathrm{H}\right]^{+}: 353.1682$, found: 353.1685 .

HPLC Chiralpak AD-H, Hexane/EtOH 80:20, $25{ }^{\circ} \mathrm{C}, 1.0 \mathrm{~mL} / \mathrm{min}, \lambda=254$ $\mathrm{nm}, \tau_{\text {major }}=12.07 \mathrm{~min}, \tau_{\text {minor }}=8.08 \mathrm{~min}$

$[\alpha]_{\mathrm{D}}{ }^{20}=-28.9\left(\mathrm{c} 0.2, \mathrm{CHCl}_{3}\right)$.

1-((5S)-5-phenyl-4,5,12,13-

tetrahydropyrrolo[2",1":3',4']pyrazino[1',2':1,6]pyrido[3,2-b]

indol-6(3bH)-yl)ethanone (7ha). Prepared according to the general procedure $\mathrm{A}$ at $0{ }^{\circ} \mathrm{C}$ using 1 -acetylindolin-3-one $(\mathbf{6 h})(35.0 \mathrm{mg}, 0.200$ mmol, 1 equiv), (E)-cinnamaldehyde (2a) $(39.7 \mathrm{mg}, 37.8 \mu \mathrm{L}, 0.300 \mathrm{mmol}$, 1.5 equiv.), $N$-(2-aminoethyl)pyrrole (3a) $(22.0 \mathrm{mg}, 21.6 \mu \mathrm{L}, 0.200 \mathrm{mmol}$, 1 equiv), with $\mathrm{CH}_{2} \mathrm{Cl}_{2}(2.5 \mathrm{~mL})$ instead of $\alpha, \alpha, \alpha$-trifluorotoluene as solvent. Purification by flash chromatography (PE/Et $204: 1)$ afforded 7 ha as a white solid (52.8 mg, $0.136 \mathrm{mmol}, 68 \%$ yield, $\sim 1.5: 1 \mathrm{dr}, 88 \%$ ee and $87 \%$ $e e$ )

\section{TLC (PE/Et 20 4:1) Rf 0.15 (UV, vanillin).}

${ }^{1} \mathrm{H}$ NMR (400 MHz, $\left.\mathbf{C D C l}_{3}\right) \delta(\mathrm{ppm})$ cis-(10S,11aR)-diastereomer (major): $8.04(\mathrm{~d}, J=8.1 \mathrm{~Hz}, 1 \mathrm{H}), 7.64(\mathrm{t}, J=7.2 \mathrm{~Hz}, 1 \mathrm{H}), 7.41-7.27(\mathrm{~m}, 3 \mathrm{H}), 7.23(\mathrm{~d}$ $J=7.7 \mathrm{~Hz}, 2 \mathrm{H}), 7.01(\mathrm{~d}, J=7.2 \mathrm{~Hz}, 2 \mathrm{H}), 6.62-6.57(\mathrm{~m}, 1 \mathrm{H}), 6.17(\mathrm{t}, J=3.1$ $\mathrm{Hz}, 1 \mathrm{H}), 5.98$ (d, $J=3.2 \mathrm{~Hz}, 1 \mathrm{H}), 4.70$ (dd, $J=10.4,7.5 \mathrm{~Hz}, 1 \mathrm{H}), 4.62$ (d, $J=$ $11.3 \mathrm{~Hz}, 1 \mathrm{H}), 4.38(\mathrm{~d}, J=10.2 \mathrm{~Hz}, 1 \mathrm{H}), 4.19-4.07(\mathrm{~m}, 1 \mathrm{H}), 3.79(\mathrm{dt}, J=12.7$ $3.9 \mathrm{~Hz}, 1 \mathrm{H}$ ), 3.57 (ddd $J=12.9,9.7,3.5 \mathrm{~Hz}, 1 \mathrm{H}), 2.50-2.42(\mathrm{~m}, 1 \mathrm{H}), 2.36$ $(\mathrm{s}, 3 \mathrm{H}), 2.04-1.91(\mathrm{~m}, 1 \mathrm{H})$; trans-(10S,11aS)-diastereomer (minor): 8.12 (d, $J=8.2 \mathrm{~Hz}, 1 \mathrm{H}), 7.64(\mathrm{t}, J=7.2 \mathrm{~Hz}, 1 \mathrm{H}), 7.40-7.27(\mathrm{~m}, 3 \mathrm{H}), 7.18(\mathrm{~d}, J=$ $7.2 \mathrm{~Hz}, 2 \mathrm{H}), 7.11(\mathrm{~d}, J=7.3 \mathrm{~Hz}, 2 \mathrm{H}), 6.62-6.57(\mathrm{~m}, 1 \mathrm{H}), 6.14(\mathrm{t}, J=3.1 \mathrm{~Hz}$ $1 \mathrm{H}), 5.77(\mathrm{~d}, J=3.3 \mathrm{~Hz}, 1 \mathrm{H}), 4.79(\mathrm{~d}, J=3.9 \mathrm{~Hz}, 1 \mathrm{H}), 4.35-4.26(\mathrm{~m}, 2 \mathrm{H})$, $4.19-4.07(\mathrm{~m}, 1 \mathrm{H}), 3.71(\mathrm{dt}, J=12.6,4.2 \mathrm{~Hz}, 1 \mathrm{H}), 3.65(\mathrm{dt}, J=7.6,3.8 \mathrm{~Hz}$, $1 \mathrm{H}), 2.56(\mathrm{td}, J=13.4,5.6 \mathrm{~Hz}, 1 \mathrm{H}), 2.48(\mathrm{~s}, 3 \mathrm{H}), 2.12(\mathrm{dt}, J=13.6,2.0 \mathrm{~Hz}$ 1H)

${ }^{13} \mathrm{C}$ NMR (101 MHz, $\left.\mathbf{C D C l}_{3}\right) \delta$ (ppm) cis-(10S,11aR)-diastereomer (major): 169.6 (C), 144.7 (C), 136.1 (C), 134.1 (C), 129.3 (C), 128.9 (2 CH), 127.9 (2 $\mathrm{CH}), 127.0(2 \mathrm{CH}), 125.1(\mathrm{CH}), 124.6(\mathrm{C}), 123.0(\mathrm{CH}), 118.7(\mathrm{CH}), 118.4$ $(\mathrm{CH}), 115.4(\mathrm{CH}), 108.4(\mathrm{CH}), 103.9(\mathrm{CH}), 54.6(\mathrm{CH}), 46.2\left(\mathrm{CH}_{2}\right), 45.7\left(\mathrm{CH}_{2}\right)$, 42.3( $\mathrm{CH}), 39.0\left(\mathrm{CH}_{2}\right), 26.8\left(\mathrm{CH}_{3}\right)$; trans-(10S,11aS)-diastereomer (minor): 169.1 (C), 145.2 (C), 135.9 (C), 131.8 (C), 129.5 (C), 128.8 (2 CH), 126.7 (2 $\mathrm{CH}), 126.6(2 \mathrm{CH}), 125.0(\mathrm{CH}), 124.2(\mathrm{C}), 123.1(\mathrm{CH}), 118.8(\mathrm{CH}), 118.5$ $(\mathrm{CH}), 116.3(\mathrm{CH}), 108.3(\mathrm{CH}), 103.6(\mathrm{CH}), 50.0(\mathrm{CH}), 46.9\left(\mathrm{CH}_{2}\right), 45.6\left(\mathrm{CH}_{2}\right)$, $40.1(\mathrm{CH}), 35.2\left(\mathrm{CH}_{2}\right), 27.2\left(\mathrm{CH}_{3}\right)$

HRMS (ESI) calc'd for [ $\left.\mathrm{C}_{25} \mathrm{H}_{23} \mathrm{~N}_{3} \mathrm{O}+\mathrm{H}\right]^{+}: 382.1914$, found: 382.1913

HPLC cis-(10S,11aR)-diastereomer (major): Chiralpak AZ-H, Hexane/ethanol $50: 50,25^{\circ} \mathrm{C}, 1.0 \mathrm{~mL} / \mathrm{min}, \lambda=254 \mathrm{~nm}, \tau_{\text {major }}=14.25 \mathrm{~min}$, $\tau_{\text {minor }}=10.45 \mathrm{~min}$; trans-(10S,11aS)-diastereomer (minor): Chiralpak AZ$\mathrm{H}$, Hexane/ethanol $50: 50,25{ }^{\circ} \mathrm{C}, 1.0 \mathrm{~mL} / \mathrm{min}, \lambda=254 \mathrm{~nm}, \tau_{\text {major }}=11.58$ $\min , \tau_{\text {minor }}=7.09 \mathrm{~min}$.

(2S,13bS)-tert-butyl 11-methoxy-4-methyl-2-phenyl-2,6,7,13btetrahydro-1H-pyrido[2',1':3,4] pyrazino [1,2-a]indole-3carboxylate (9). A reaction tube was charged with $(S)-\alpha, \alpha$-bis $[3,5-$ bis(trifluoromethyl)phenyl]-2-pyrrolidinemethanol trimethylsilyl ether (4) $(12.0 \mathrm{mg}, 0.020 \mathrm{mmol}, 0.1$ equiv), dry $\alpha, \alpha, \alpha$-trifluorotoluene $(2.5 \mathrm{~mL})$, flushed with argon and placed at $0{ }^{\circ} \mathrm{C}$. tert-butyl acetoacetate (1a) $(31.6$ $\mathrm{mg}, 32.9 \mu \mathrm{L}, 0.200 \mathrm{mmol}, 1$ equiv) and (E)-cinnamaldehyde (2a) $(39.7 \mathrm{mg}$, $37.8 \mu \mathrm{L}, 0.300 \mathrm{mmol}, 1.5$ equiv) were then added. After full conversion of tert-butyl acetoacetate (1a) as monitored by TLC $(48 \mathrm{~h})$, followed by the addition of 2-(5-methoxy-1H-indol-1-yl)ethanamine (8) (38.0 mg, 0.200 mmol, 1 equiv), the mixture was stirred at $0{ }^{\circ} \mathrm{C}$ for another $24 \mathrm{~h}$. After reaction, the solution was filtered through a short pad of silica gel, which was thoroughly washed with EtOAc. The solvent was evaporated by reduced pressure to obtain the crude compound, which was analyzed by ${ }^{1} \mathrm{H}$ NMR, which was identified as the dihydropyridine 10. Purification by 
flash column chromatography (PE/EtOAc 80:20 and then $\mathrm{PE} / \mathrm{EtOAc} / \mathrm{AcOH}$ 80:20:0.5) on silica gel provided the pure trans$(2 S, 13 \mathrm{bS})$-indolopiperazine 9 as pale yellow solid $(28.4 \mathrm{mg}, 0.064 \mathrm{mmol}$, $32 \%$ yield, $85 \%$ ee).

\section{TLC (PE/EtOAc 4:1) R $f 0.53$ (UV, vanillin)}

${ }^{1}$ H NMR (400 MHz, $\left.\mathbf{C D C l}_{3}\right) \delta(\mathrm{ppm}) 7.34-7.27(\mathrm{~m}, 2 \mathrm{H}), 7.27-7.17(\mathrm{~m}$ $3 \mathrm{H}), 7.15$ (d, $J=8.8 \mathrm{~Hz}, 1 \mathrm{H}), 7.00$ (d, $J=2.3 \mathrm{~Hz}, 1 \mathrm{H}), 6.82$ (dd, $J=8.8,2.3$ $\mathrm{Hz}, 1 \mathrm{H}), 6.09(\mathrm{~s}, 1 \mathrm{H}), 4.38-4.23(\mathrm{~m}, 2 \mathrm{H}), 4.21-4.08(\mathrm{~m}, 2 \mathrm{H}), 4.02(\mathrm{td}, J=$ $11.3,4.2 \mathrm{~Hz}, 1 \mathrm{H}$ ), 3.83 (s, $3 \mathrm{H}$ ), 3.41 (ddd, $J=13.9,11.5,3.7 \mathrm{~Hz}, 1 \mathrm{H}), 2.55(\mathrm{~s}$ $3 \mathrm{H}), 2.40$ (dt, $J=13.3,3.3 \mathrm{~Hz}, 1 \mathrm{H}), 2.25$ (ddd, $J=13.2,11.3,5.7 \mathrm{~Hz}, 1 \mathrm{H}$ ), $1.18(\mathrm{~s}, 9 \mathrm{H})$.

${ }^{13} \mathrm{C}$ NMR (101 MHz, CDCl $_{3}$ ) $\delta$ (ppm) 168.5 (C), 154.6 (C), 152.5 (C), 147.5 (C), $137.9(\mathrm{C}), 131.3(\mathrm{C}), 128.7(\mathrm{C}), 128.3(\mathrm{C}), 128.3(2 \mathrm{CH}), 128.1(2 \mathrm{CH})$ $126.0(\mathrm{CH}), 111.2(\mathrm{CH}), 109.3(\mathrm{CH}), 102.5(\mathrm{CH}), 96.1(\mathrm{CH}), 78.8(\mathrm{C}), 56.1$ $\left(\mathrm{CH}_{3}\right), 50.2(\mathrm{CH}), 44.3\left(\mathrm{CH}_{2}\right), 42.6\left(\mathrm{CH}_{2}\right), 38.9(\mathrm{CH}), 36.1\left(\mathrm{CH}_{2}\right), 28.2(3$ $\left.\mathrm{CH}_{3}\right), 17.5\left(\mathrm{CH}_{3}\right)$.

HRMS (ESI) calc'd for [ $\left.\mathrm{C}_{28} \mathrm{H}_{32} \mathrm{~N}_{2} \mathrm{O}_{3}+\mathrm{H}\right]^{+}: 445.2486$, found: 445.2485 .

HPLC Chiralpak AZ-H, Heptane/ethanol 90:10, $25^{\circ} \mathrm{C}, 1.0 \mathrm{~mL} / \mathrm{min}, \lambda=254$ $\mathrm{nm}, \tau_{\text {major }}=11.47 \mathrm{~min}, \tau_{\text {minor }}=9.83 \mathrm{~min}$

(S)-tert-butyl 1-(2-(5-methoxy-1H-indol-1-yl)ethyl)-2-methyl-4phenyl-1,4-dihydropyridine-3-carboxylate (10). A reaction tube was charged with (S)- $\alpha, \alpha$-bis[3,5-bis(trifluoromethyl)phenyl]-2pyrrolidinemethanol trimethylsilyl ether (4) $(12.0 \mathrm{mg}, 0.020 \mathrm{mmol}, 0.1$ equiv), dry $\alpha, \alpha, \alpha$-trifluorotoluene $(2.5 \mathrm{~mL})$, flushed with argon and placed at $0{ }^{\circ}$ C. tert-butyl acetoacetate (1a) $(31.6 \mathrm{mg}, 32.9 \mu \mathrm{L}, 0.200 \mathrm{mmol}, 1$ equiv) and (E)-cinnamaldehyde (2a) (39.7 mg, $37.8 \mu \mathrm{L}, 0.300 \mathrm{mmol}, 1.5$ equiv) were then added. After full conversion of tert-butyl acetoacetate (1a) as monitored by TLC ( $48 \mathrm{~h})$, followed by the addition of 2-(5methoxy-1H-indol-1-yl)ethanamine 8 ( $38.0 \mathrm{mg}, 0.200 \mathrm{mmol}, 1$ equiv), the mixture was stirred at $0{ }^{\circ} \mathrm{C}$ for another $24 \mathrm{~h}$. After reaction, the solution was filtered through a short pad of silica gel, which was thoroughly washed with EtOAc. The solvent was evaporated by reduced pressure to obtain the crude compound, which was analyzed by ${ }^{1} \mathrm{H}$ NMR, which was identified as the dihydropyridine 10. Purification by flash column chromatography over aluminium oxide 90 neutral (PE/EtOAc 85:15) provided the pure $(S)$-dihydropyridine $\mathbf{1 0}$ as pale yellow solid $(26.3 \mathrm{mg}$ $0.060 \mathrm{mmol}, 30 \%$ yield, $91 \% \mathrm{ee}$ )

TLC (PE/EtOAc 6:1) R $f 0.42$ (UV, vanillin).

${ }^{1} \mathrm{H}$ NMR (400 MHz, CDCl $\left._{3}\right) \delta(\mathrm{ppm}) 7.31-7.26(\mathrm{~m}, 1 \mathrm{H}), 7.23-7.19(\mathrm{~m}$ $3 \mathrm{H}), 7.18-7.18-7.12(\mathrm{~m}, 1 \mathrm{H}), 7.09(\mathrm{~d}, J=2.3 \mathrm{~Hz}, 1 \mathrm{H}), 6.98(\mathrm{~d}, J=3.1 \mathrm{~Hz}$ $1 \mathrm{H}), 6.89$ (dd, $J=8.8,2.3 \mathrm{~Hz}, 1 \mathrm{H}), 6.43(\mathrm{~d}, J=2.6 \mathrm{~Hz}, 1 \mathrm{H}), 5.61(\mathrm{~d}, J=7.8$ $\mathrm{Hz}, 1 \mathrm{H}), 4.83(\mathrm{dd}, J=7.8,5.0 \mathrm{~Hz}, 1 \mathrm{H}), 4.55(\mathrm{~d}, J=5.0 \mathrm{~Hz}, 1 \mathrm{H}), 4.35-4.14$ (m, 2H), $3.85(\mathrm{~s}, 3 \mathrm{H}), 3.84-3.73(\mathrm{~m}, 2 \mathrm{H}), 3.60(\mathrm{dt}, J=15.0,6.2 \mathrm{~Hz}, 1 \mathrm{H})$ $2.19(\mathrm{~s}, 3 \mathrm{H}), 1.21(\mathrm{~s}, 9 \mathrm{H})$.

${ }^{13}$ C NMR (101 MHz, CDCl $_{3}$ ) $\delta$ (ppm) 168.5 (C), 154.3 (C), 149.1 (C), 146.4 (C), 131.1 (C), $129.4(\mathrm{C}), 128.7(\mathrm{CH}), 128.3(2 \mathrm{CH}), 127.8(\mathrm{CH}), 127.6(2$ (CH), $126.1(\mathrm{CH}), 112.4(\mathrm{CH}), 109.6(\mathrm{CH}), 108.5(\mathrm{CH}), 103.0(\mathrm{CH}), 102.7(\mathrm{C})$ $101.8(\mathrm{CH}), 79.2(\mathrm{C}), 56.0\left(\mathrm{CH}_{3}\right), 49.7\left(\mathrm{CH}_{2}\right), 46.6\left(\mathrm{CH}_{2}\right), 41.1(\mathrm{CH}), 28.2(3$ $\left.\mathrm{CH}_{3}\right), 15.5\left(\mathrm{CH}_{3}\right)$.

HRMS (ESI) calc'd for $\left[\mathrm{C}_{28} \mathrm{H}_{32} \mathrm{~N}_{2} \mathrm{O}_{3}+\mathrm{H}\right]^{+}: 445.2486$, found: 445.2487 .

HPLC Chiralpak AZ-H, Heptane/ethanol 90:10, $25^{\circ} \mathrm{C}, 1.0 \mathrm{~mL} / \mathrm{min}, \lambda=254$ $\mathrm{nm}, \tau_{\text {major }}=12.11 \mathrm{~min}, \tau_{\mathrm{minor}}=14.10 \mathrm{~min}$.

(3S)-tert-butyl 1-methyl-3-phenyl-3,4,4a,6 tetrahydrobenzo[d]pyrido[2,1-b][1,3] oxazine-2-carboxylate (13c) Prepared according to the general procedure A using tert-butyl acetoacetate (1a) $(31.6 \mathrm{mg}, 32.9 \mu \mathrm{L}, 0.200 \mathrm{mmol}, 1$ equiv), (E)cinnamaldehyde (2a) (39.7 mg, $37.8 \mu \mathrm{L}, 0.300 \mathrm{mmol}, 1.5$ equiv), 2 aminobenzyl alcohol (11c) $24.6 \mathrm{mg}, 0.200 \mathrm{mmol}, 1$ equiv). Purification by flash chromatography over silica gel (PE/Et ${ }_{2} \mathrm{O}$ 80:20) afforded 12c as a pale yellow solid ( $\sim 20 \mathrm{mg}, \sim 0.050 \mathrm{mmol}, \sim 2 \%$ yield, $1.3: 1 \mathrm{dr}, 88 \% e e$ ). TLC (PE/Et $\mathbf{t}_{2} \mathbf{O}$ 80:10) R $f 0.36$ and 0.40 (UV, vanillin).

${ }^{1} \mathbf{H}$ NMR (400 MHz, $\left.\mathbf{C D C l}_{3}\right) \delta(\mathrm{ppm})$ major diastereomer: $7.35-7.17(\mathrm{~m}$, $5 \mathrm{H}), 7.00(\mathrm{t}, J=7.5 \mathrm{~Hz}, 1 \mathrm{H}), 6.85(\mathrm{~d}, J=7.5 \mathrm{~Hz}, 1 \mathrm{H}), 6.75(\mathrm{t}, J=7.5 \mathrm{~Hz}, 1 \mathrm{H})$, $6.52(\mathrm{~d}, J=7.5 \mathrm{~Hz}, 1 \mathrm{H}), 4.79(\mathrm{~d}, J=14.3 \mathrm{~Hz}, 1 \mathrm{H}), 4.68(\mathrm{~d}, J=14.3 \mathrm{~Hz}, 1 \mathrm{H})$,
$4.19-4.09$ (m, 1H), $3.80-3.75(\mathrm{~m}, 1 \mathrm{H}), 2.33(\mathrm{~s}, 3 \mathrm{H}), 2.15-1.78(\mathrm{~m}, 2 \mathrm{H})$ $1.10(\mathrm{~s}, 9 \mathrm{H})$; minor diastereomer: $7.35-7.17(\mathrm{~m}, 5 \mathrm{H}), 7.07(\mathrm{t}, J=6.9 \mathrm{~Hz}$, $1 \mathrm{H}), 6.85(\mathrm{~d}, J=7.5 \mathrm{~Hz}, 1 \mathrm{H}), 6.80-6.72(\mathrm{~m}, 2 \mathrm{H}), 4.74(\mathrm{app} \mathrm{s}, 2 \mathrm{H}), 4.27-$ $4.19(\mathrm{~m}, 1 \mathrm{H}), 3.80-3.73(\mathrm{~m}, 1 \mathrm{H}), 2.31(\mathrm{~s}, 3 \mathrm{H}), 2.10-1.82(\mathrm{~m}, 2 \mathrm{H}), 1.10(\mathrm{~s}$ $9 \mathrm{H})$.

HPLC Chiralpak AD-H, Hexane/ethanol 90:10, $25^{\circ} \mathrm{C}, 1.0 \mathrm{~mL} / \mathrm{min}, \lambda=254$ $\mathrm{nm}$, major diastereromer: $\tau_{\text {minor }}=15.72 \mathrm{~min}, \tau_{\text {major }}=22.33 \mathrm{~min} ;$ minor diastereromer: $\tau_{\text {minor }}=17.95 \mathrm{~min}, \tau_{\text {major }}=19.12 \mathrm{~min}$

(3R,4S,4aR)-tert-butyl 4a-methyl-3-phenyl-4,4a-dihydro-3Hbenzo[4,5]oxazolo[3,2-a]pyridine-4-carboxylate (15). Prepared according to the general procedure A using tert-butyl acetoacetate (1a) (31.6 mg, $32.9 \mu \mathrm{L}, 0.200 \mathrm{mmol}, 1$ equiv), (E)-cinnamaldehyde (2a) $(39.7$ $\mathrm{mg}, 37.8 \mu \mathrm{L}, 0.300 \mathrm{mmol}, 1.5$ equiv), 2-aminophenol (12a) $(21.8 \mathrm{mg}, 0.200$ mmol, 1 equiv). Purification by flash chromatography over silica gel (PE/Et $\left.{ }_{2} \mathrm{O} 90: 10\right)$ afforded $\mathbf{1 5}$ as a pale yellow oil $(18.2 \mathrm{mg}, 0.050 \mathrm{mmol}$ $25 \%$ yield, $>20: 1 d r, 92 \% e e$ ). More polar regioisomer 14 could not be obtained pure.

TLC (PE/Et $\mathbf{E}_{2}$ O 80:20) R $f 0.45$ (UV, vanillin).

HRMS (ESI) calc'd for $\left[\mathrm{C}_{23} \mathrm{H}_{25} \mathrm{NO}_{3}+\mathrm{H}\right]+:$ : 364.1907, found: 364.1909 .

${ }^{1} \mathrm{H}$ NMR (400 MHz, $\left.\mathbf{C D C l}_{3}\right) \delta(\mathrm{ppm}) 7.26-7.16(\mathrm{~m}, 5 \mathrm{H}), 6.82-6.77(\mathrm{~m}$, $1 \mathrm{H}), 6.73-6.66(\mathrm{~m}, 2 \mathrm{H}), 6.63-6.59(\mathrm{~m}, 1 \mathrm{H}), 6.54(\mathrm{dd}, J=7.6,2.1 \mathrm{~Hz}, 1 \mathrm{H})$, $4.82(\mathrm{dd}, J=7.6,2.0 \mathrm{~Hz}, 1 \mathrm{H}), 3.81(\mathrm{dt}, J=11.9,2.0 \mathrm{~Hz}, 1 \mathrm{H}), 2.92(\mathrm{~d}, J=$ $11.9 \mathrm{~Hz}, 1 \mathrm{H}), 1.70$ (s, 3H), 1.21 (s, 9H).

${ }^{13}$ C NMR (101 MHz, CDCl 3 ) $\delta(\mathrm{ppm}) 170.3$ (C), 149.8 (C), 141.7 (C), 134.6 (C), $128.5(2 \mathrm{CH}), 128.3(2 \mathrm{CH}), 127.3(\mathrm{CH}), 124.0(\mathrm{CH}), 121.4(\mathrm{CH}), 120.2$ (CH), $108.9(\mathrm{CH}), 107.0(\mathrm{CH}), 106.9(\mathrm{CH}), 100.0(\mathrm{C}), 81.2(\mathrm{C}), 54.9(\mathrm{CH})$ $43.4(\mathrm{CH}), 28.0\left(3 \mathrm{CH}_{3}\right), 20.8\left(\mathrm{CH}_{3}\right)$

HPLC Chiralpak IA, Hexane/isopropanol 95:5, $25^{\circ} \mathrm{C}, 1.0 \mathrm{~mL} / \mathrm{min}, \lambda=254$ $\mathrm{nm}, \tau_{\text {major }}=4.99 \mathrm{~min}, \tau_{\text {minor }}=5.99 \mathrm{~min}$.

$[\boldsymbol{\alpha}]_{\mathbf{D}^{20}}=-11.3\left(\mathrm{c} 0.3, \mathrm{CHCl}_{3}\right)$.

4-bromo- $\boldsymbol{N}$-methoxy- $\boldsymbol{N}$-methyl-3-oxobutanamide (17d). To a solution of $N$-methoxy- $N$-methyl-3-oxobutanamide $(\mathbf{6 d})(1.02 \mathrm{~g}, 7 \mathrm{mmol}, 1$ equiv $)$ in dry chloroform $(10 \mathrm{~mL})$ at $0{ }^{\circ} \mathrm{C}$ was added bromine $(360 \mu \mathrm{L}, 7 \mathrm{mmol}, 1$ equiv) dropwise over $45 \mathrm{~min}$ with vigorous stirring. After the mixture was stirred at room temperature for $24 \mathrm{~h}$, cold water was added $(20 \mathrm{~mL})$, and the organic layer washed with a sodium thiosulfate aqueous solution $(3 \mathrm{x}$ $20 \mathrm{~mL}$ ). The organic layer was dried over sodium sulfate, filtered and the solvent was removed under reduced pressure. Purification by flash column chromatography over silica gel (PE/EtOAc 70:30 to 50:50) yielded product $\mathbf{1 7 d}$ as an orange oil $(710 \mathrm{mg}, 3.17 \mathrm{mmol}, 45 \%$ yield, $\sim 1.3: 1$ ketone vs enol forms).

TLC (PE/EtOAc 50:50) R $f 0.23$ (UV, $p$-anisaldehyde).

HRMS (ESI) calc'd for $\left[\mathrm{C}_{6} \mathrm{H}_{10} \mathrm{BrNO}_{3}+\mathrm{H}\right]^{+}:$223.9917, found: 223.9915

${ }^{1}$ H NMR (400 MHz, $\mathbf{C D C l}_{3}$ ): $\delta(\mathrm{ppm})$ ketone form: $4.04(\mathrm{~s}, 2 \mathrm{H}), 3.79(\mathrm{~s}, 2 \mathrm{H})$ $3.68(\mathrm{~s}, 3 \mathrm{H}), 3.19$ (s, 3H); enol form: $13.68(\mathrm{~s}, 1 \mathrm{H}), 5.67(\mathrm{~s}, 1 \mathrm{H}), 3.85(\mathrm{~s}, 2 \mathrm{H})$ $3.68(\mathrm{~s}, 3 \mathrm{H}), 3.19(\mathrm{~s}, 3 \mathrm{H})$.

${ }^{13}$ C NMR (101 MHz, $\mathbf{C D C l}_{3}$ ): $\delta$ (ppm) ketone form: 195.7 (C), 170.5 (C), $61.6\left(\mathrm{CH}_{3}\right), 44.6\left(\mathrm{CH}_{2}\right), 32.2\left(\mathrm{CH}_{3}\right), 34.4\left(\mathrm{CH}_{2}\right)$; enol form: $171.6(\mathrm{C}), 167.4$ (C), $88.6(\mathrm{CH}), 61.7\left(\mathrm{CH}_{3}\right), 31.8\left(\mathrm{br}, \mathrm{CH}_{3}\right), 29.9\left(\mathrm{CH}_{2}\right)$

1-(2-oxopyrrolidin-1-yl)butane-1,3-dione (20). 2-Pyrrolidinone (19) $(1.70 \mathrm{~g}, 20 \mathrm{mmol}, 1$ equiv) was dissolved in dry toluene $(10 \mathrm{~mL})$ under argon atmosphere. Then, 2,2,6-trimethyl-4H-1,3-dioxin-4-one (18) 2.63 $\mathrm{mL}, 20 \mathrm{mmol}, 1$ equiv) was added and the reactor was irradiated under microwave at $150^{\circ} \mathrm{C}$ during $30 \mathrm{~min}$. Solvent was removed under reduced pressure. Purification by flash column chromatography over silica gel (PE/EtOAc 70:30 to 50:50) yielded product 20 as an orange oil (2.65 g, $15.7 \mathrm{mmol}, 78 \%$ yield, $9: 1$ ketone vs enol forms).

TLC (PE/EtOAc 50:50) R $f 0.20$ (UV, $p$-anisaldehyde).

HRMS (ESI) calc'd for $\left[\mathrm{C}_{8} \mathrm{H}_{11} \mathrm{NO}_{3}+\mathrm{H}\right]^{+}: 170.0812$, found: 170.0814 .

${ }^{1} \mathrm{H}$ NMR (400 MHz, $\left.\mathbf{C D C l}_{3}\right) \delta(\mathrm{ppm})$ ketone form: $3.92(\mathrm{~s}, 2 \mathrm{H}), 3.79(\mathrm{t}, J=$ $7.2 \mathrm{~Hz}, 2 \mathrm{H}), 2.51(\mathrm{t}, J=8.1 \mathrm{~Hz}, 2 \mathrm{H}), 2.20(\mathrm{~s}, 3 \mathrm{H}), 2.06-1.95(\mathrm{~m}, 2 \mathrm{H})$. NMR signals are in accordance with literature. ${ }^{44}$ 
$(3 R, 4 S, 4 a R)-N$-methoxy- $N, 4 a-d i m e t h y l-3-p h e n y l-2,3,4,4 a-$ tetrahydro-1H-benzo[4,5]oxazolo[3,2-a]pyridine-4-carboxamide (23). The three-component product 16a (144 mg, $0.411 \mathrm{mmol}, 1$ equiv) was dissolved in methanol $(15 \mathrm{~mL})$ under argon atmosphere. Then, Pd/C (18 $\mathrm{mg}, 0.164 \mathrm{mmol}, 12 \mathrm{wt} . \%$ ) was added to the solution before flushing the reaction mixture with hydrogen. The reaction was stirred at room temperature during $13 \mathrm{~h}$. After filtration on celite and washing with $\mathrm{CH}_{2} \mathrm{Cl}_{2}$, solvents were removed under vacuum. Purification by flash column chromatography over silica gel (PE/EtOAc 80:20 to 50:50) yielded the hydrogenated product 23 as a yellowish oil $(117 \mathrm{mg}, 0.332 \mathrm{mmol}, 81$ $\%$ yield, $>20: 1 d r$ )

TLC (PE/EtOAc 70:30) R $f 0.65$ (UV, $p$-anisaldehyde).

HRMS (ESI) calc'd for $\left[\mathrm{C}_{21} \mathrm{H}_{22} \mathrm{~N}_{2} \mathrm{O}_{3}+\mathrm{H}\right]^{+}: 353.1860$, found: 353.1862

${ }^{1} \mathrm{H}$ NMR (400 MHz, $\left.\mathbf{C D C l}_{3}\right) \delta(\mathrm{ppm}) 7.24-7.11(\mathrm{~m}, 5 \mathrm{H}), 6.88-6.80(\mathrm{~m}$ $1 \mathrm{H}), 6.69-6.61(\mathrm{~m}, 2 \mathrm{H}), 6.45(\mathrm{~d}, J=7.4 \mathrm{~Hz}, 1 \mathrm{H}), 3.95(\mathrm{~d}, J=10.4 \mathrm{~Hz}, 1 \mathrm{H})$, 3.75 (ddd, $J=14.7,4.2,1.6 \mathrm{~Hz}, 1 \mathrm{H}), 3.62(\mathrm{~s}, 3 \mathrm{H}), 3.40-3.17(\mathrm{~m}, 2 \mathrm{H}), 2.86$ (s, 3H), $1.91(\mathrm{~s}, 3 \mathrm{H}), 1.87-1.75$ (td, $J=12.7,4.2 \mathrm{~Hz}, 1 \mathrm{H}), 1.71(\mathrm{~s}, 1 \mathrm{H})$.

${ }^{13} \mathrm{C}$ NMR (101 MHz, CDCl $) \delta 172.1$ (C), 148.7 (C), 142.5 (C), 138.8 (C) $128.3(2 \mathrm{CH}), 127.7(2 \mathrm{CH}), 126.7(\mathrm{CH}), 121.7(\mathrm{CH}), 118.4(\mathrm{CH}), 108.5(\mathrm{CH})$, $105.6(\mathrm{CH}), 102.2(\mathrm{C}), 61.2\left(\mathrm{CH}_{3}\right), 47.8(\mathrm{CH}), 43.6\left(\mathrm{CH}_{3}\right), 41.7\left(\mathrm{CH}_{2}\right), 32.0$ (CH), $30.5\left(\mathrm{CH}_{2}\right), 20.4\left(\mathrm{CH}_{3}\right)$.

$[\alpha]_{\mathrm{D}^{20}}=+162\left(\mathrm{c} 1.0, \mathrm{CHCl}_{3}\right)$

(2S,3S,4R)-1-(2-hydroxyphenyl)- $N$-methoxy- $N$,2-dimethyl-4-phenyl2-(phenylethynyl) piperidine -3-carboxamide (25). A mixture of product $23(64 \mathrm{mg}, \quad 0.182 \mathrm{mmol}, \quad 1$ equiv), potassium phenylethynyltrifluoroborate (24) $(99 \mathrm{mg}, 0.436 \mathrm{mmol}, 2.4$ equiv) and scandium (III) triflate $(17.9 \mathrm{mg}, 0.036 \mathrm{mmol}, 0.2$ equiv) was dissolved in dry $\mathrm{CH}_{2} \mathrm{Cl}_{2}(2 \mathrm{~mL})$ under argon atmosphere. The reaction mixture was stirred at room temperature during $40 \mathrm{~h}$. After filtration on celite, the $\mathrm{CH}_{2} \mathrm{Cl}_{2}$ was removed under vacuum. Purification by flash column chromatography over silica gel (cyclohexane/EtOAc 75:25) yielded product 25 as a colorless oil ( $35 \mathrm{mg}, 0.077 \mathrm{mmol}, 42 \%$ yield, $>20: 1 \mathrm{dr}$ ).

TLC (Cyclohexane/EtOAc 75:25) R 0.47 (UV, $p$-anisaldehyde).

HRMS (ESI) calc'd for $\left[\mathrm{C}_{29} \mathrm{H}_{30} \mathrm{~N}_{2} \mathrm{O}_{3}+\mathrm{H}\right]^{+}: 455.2329$, found: 455.2328 .

${ }^{1} \mathrm{H}$ NMR (400 MHz, $\left.\mathbf{C D C l}_{3}\right) \delta(\mathrm{ppm}) 9.00(\mathrm{~s}, 1 \mathrm{H}), 7.62-7.57(\mathrm{~m}, 2 \mathrm{H}), 7.55$ (dd, $J=7.8,1.4 \mathrm{~Hz}, 1 \mathrm{H}), 7.43-7.37(\mathrm{~m}, 3 \mathrm{H}), 7.35-7.17(\mathrm{~m}, 5 \mathrm{H}), 7.11$ (td, $=7.9,1.4 \mathrm{~Hz}, 1 \mathrm{H}), 6.95(\mathrm{dd}, J=8.1,1.2 \mathrm{~Hz}, 1 \mathrm{H}), 6.79(\mathrm{td}, J=7.6,1.3 \mathrm{~Hz}, 1 \mathrm{H})$, $3.77-3.62(\mathrm{~m}, 2 \mathrm{H}), 3.56(\mathrm{~d}, J=4.4 \mathrm{~Hz}, 1 \mathrm{H}), 3.08-2.95(\mathrm{~m}, 2 \mathrm{H}), 3.01(\mathrm{~s}, 3 \mathrm{H})$ $2.94(\mathrm{~s}, 3 \mathrm{H}), 1.74-1.64(\mathrm{~m}, 1 \mathrm{H}), 1.22(\mathrm{~s}, 3 \mathrm{H})$

${ }^{13}$ C NMR (101 MHz, CDCl $_{3}$ ) $\delta$ (ppm) 172.9 (C), 155.8 (C), 143.3 (C), 135.5 (C), $131.9(2 \mathrm{CH}), 128.6(2 \mathrm{CH}), 128.52(\mathrm{CH}), 128.50(2 \mathrm{CH}), 128.3(2 \mathrm{CH})$, $127.7(\mathrm{CH}), 127.1(\mathrm{CH}), 126.1(\mathrm{CH}), 123.2(\mathrm{C}), 119.2(\mathrm{CH}), 114.4(\mathrm{CH}), 90.7$ (C), $86.5(\mathrm{C}), 60.7\left(\mathrm{CH}_{3}\right), 57.9(\mathrm{C}), 50.8(\mathrm{CH}), 50.5\left(\mathrm{CH}_{2}\right), 43.4\left(\mathrm{CH}_{3}\right), 31.9$ (CH), $27.5\left(\mathrm{CH}_{2}\right), 24.8\left(\mathrm{CH}_{3}\right)$.

$[\alpha]_{\mathrm{D}^{20}}=+162\left(\mathrm{c} 1.0, \mathrm{CHCl}_{3}\right)$.

Ethyl $\quad(6 \mathrm{a} S, 7 R, 8 S, 8 \mathrm{a} R, 14 \mathrm{a} S)-8$-(methoxy(methyl)carbamoyl)-2,8adimethyl-7-phenyl-5,6a,7,8,8a,14a-hexahydro- $6 \mathrm{H}$ -

benzo $[h]$ benzo[4,5]oxazolo[3,2-a][1,6]naphthyridine-6-carboxylate (28). 4 Å molecular sieves (ca. $600 \mathrm{mg}$ ) and Sc(OTf) $3(9.8 \mathrm{mg} 0.020 \mathrm{mmol}$ 0.2 equiv) were added to a solution of ethyl glyoxalate (26) $(50 \%$ in toluene, $13 \mu \mathrm{L}, 0.100 \mathrm{mmol}, 1$ equiv) and $p$-toluidine (27) (10.7 mg, 0.100 mmol, 1 equiv) in dry $\mathrm{CH}_{3} \mathrm{CN}(2 \mathrm{~mL})$, and the mixture as stirred at room temperature. After $5 \mathrm{~min}$, the three-component product $16 \mathbf{3}(35 \mathrm{mg}$ $0.100 \mathrm{mmol}, 1$ equiv) was added, and the resulting suspension was stirred under argon atmosphere at the same temperature for $48 \mathrm{~h}$. An aqueous saturated $\mathrm{NaHCO}_{3}$ solution $(5 \mathrm{~mL})$ was added, and the resulting mixture was extracted with $\mathrm{CH}_{2} \mathrm{Cl}_{2}(3 \times 5 \mathrm{~mL})$. The organic layer was dried over $\mathrm{Na}_{2} \mathrm{SO}_{4}$, filtered and the solvent was removed under vacuum. The residue was purified by flash chromatography on silica gel (PE/EtOAc 70:30) to afford the desired piperidine $\mathbf{2 8}$ as a colorless oil $(41 \mathrm{mg}, 0.076 \mathrm{mmol}$, $76 \%$ yield, $1.6: 1 \mathrm{dr}$ ).

TLC (PE/EtOAc 70:30) R $f 0.47$ (UV, $p$-anisaldehyde).

HRMS (ESI) calc'd for $\left[\mathrm{C}_{32} \mathrm{H}_{35} \mathrm{~N}_{3} \mathrm{O}_{5}+\mathrm{H}\right]^{+}: 542.2649$, found: 542.2650 .
${ }^{1} \mathrm{H}$ NMR (400 MHz, $\mathbf{C D C l}_{3}$ ) $\delta$ (ppm) Most aromatic protons and $\mathrm{NH}$ could not be attributed unambiguously to one diastereomer or the other: major diastereomer $7.34-7.27(\mathrm{~m}, 2 \mathrm{H}), 7.23-7.08(\mathrm{~m}, 2$ or $3 \mathrm{H}), 7.00-6.85(\mathrm{~m}$ 3 or $4 \mathrm{H}), 6.74-6.66(\mathrm{~m}, 2 \mathrm{H}), 6.65-6.52(\mathrm{~m}, 2 \mathrm{H}), 5.33(\mathrm{~d}, J=5.8 \mathrm{~Hz}, 1 \mathrm{H})$ 4.32 or $3.98(\mathrm{~s}, 1 \mathrm{H}, \mathrm{NH}), 4.29-4.00(\mathrm{~m}, 1 \mathrm{H}), 3.68(\mathrm{~s}, 3 \mathrm{H}), 3.63-3.50(\mathrm{~m}$, $3 \mathrm{H}), 3.14-3.04(\mathrm{~m}, 1 \mathrm{H}), 2.99(\mathrm{dd}, J=11.3,5.7 \mathrm{~Hz}, 1 \mathrm{H}), 2.68(\mathrm{~s}, 3 \mathrm{H}), 2.24$ $(\mathrm{s}, 3 \mathrm{H}), 1.46(\mathrm{~s}, 3 \mathrm{H}), 1.04(\mathrm{t}, J=7.2 \mathrm{~Hz}, 3 \mathrm{H})$; minor diastereomer $7.34-7.27$ (m, 2H), $7.23-7.08(\mathrm{~m}, 2$ or $3 \mathrm{H}), 7.00-6.85(\mathrm{~m}, 3$ or $4 \mathrm{H}), 6.74-6.66(\mathrm{~m}$ $2 \mathrm{H}), 6.65-6.52(\mathrm{~m}, 2 \mathrm{H}), 5.06(\mathrm{~d}, J=5.7 \mathrm{~Hz}, 1 \mathrm{H}), 4.32$ or $3.98(\mathrm{~s}, 1 \mathrm{H}, \mathrm{NH})$, $4.29-4.00(\mathrm{~m}, 3 \mathrm{H}), 3.66(\mathrm{~s}, 3 \mathrm{H}), 3.44(\mathrm{t}, J=11.9 \mathrm{~Hz}, 1 \mathrm{H}), 3.36(\mathrm{~d}, J=2.6 \mathrm{~Hz}$, $1 \mathrm{H}), 2.84$ (ddd, $J=11.9,5.9,2.7 \mathrm{~Hz}, 1 \mathrm{H}), 2.76(\mathrm{~s}, 3 \mathrm{H}), 2.22(\mathrm{~s}, 3 \mathrm{H}), 1.54(\mathrm{~s}$, $3 \mathrm{H}), 1.22(\mathrm{t}, J=7.1 \mathrm{~Hz}, 3 \mathrm{H})$.

${ }^{13} \mathrm{C}$ NMR (101 MHz, $\left.\mathrm{CDCl}_{3}\right)$ : The complexity of the structure, its existence as two diastereomers, which causes overlaps between some signals, and its moderate stability made it difficult to obtain a complete ${ }^{13} \mathrm{C}$ NMR description. For each diastereomer, 30 signals are expected: 2 carbonyls, 6 aromatic $\mathrm{C}, 10$ aromatic $\mathrm{CH}$ (including two accounting for two carbon atoms), 1 aliphatic $\mathrm{C}$ (aminal), 5 aliphatic $\mathrm{CH}, 1$ aliphatic $\mathrm{CH}_{2}$ and 5 aliphatic $\mathrm{CH}_{3} . \delta$ (ppm): 173.6, 173.4, 171.5, 170.1 (carbonyl C); 148.4, 143.9, 141.5, 140.7, 140.1, 140.0, 139.7, 138.5, 137.4, 131.8, 131.3, 120.1, (aromatic C); 133.1, 129.9, 129.9, 129.5, 129.4, 129.4, 128.6, 127.9, 127.8, 127.2, 127.0, 121.7, 121.6, 118.7, 118.6, 115.4, 115.3, 115.2, 108.4, 105.1 (aromatic CH); 102.3, 102.1 (aminal C); 61.5, 61.0 (aliphatic $\mathrm{CH}_{2}$ ); 77,4, 61.3, 57.7, 55.6, 55.3, 50.3, 48.5, 42.3, 40.2, 38.6, 32.1, 30.5, 23.7, 20.8, 20.7, 14.4, 14.3, 14.2, 13.8 (aliphatic $\mathrm{CH}$ and $\mathrm{CH}_{3}$ ).

HPLC Chiralpak IE, Heptane/Ethanol 80:20, $1 \mathrm{~mL} / \mathrm{min}, \lambda=254 \mathrm{~nm}$, major diastereomer: $\tau_{\text {minor }}=7.35 \mathrm{~min}, \tau_{\text {major }}=9.19 \mathrm{~min}$, minor diastereomer $\tau_{\text {minor }}=12.43 \mathrm{~min}, \tau_{\text {major }}=13.98 \mathrm{~min}$.

$[\alpha]_{\mathrm{D}^{20}}=+146\left(\mathrm{c} 1.0, \mathrm{CHCl}_{3}\right)$.

(3R,4S,4aR)-3-(4-fluorophenyl)- $N$-methoxy- $N, 4 a-d i m e t h y l-4,4 a-$ dihydro-3H-benzo[4,5]oxazolo[3,2-a]pyridine-4-carboxamide (29). Prepared according to the general procedure $B$ using Weinreb $\beta$ ketoamide (6d) $(29.0 \quad \mathrm{mg}, \quad 0.200 \quad \mathrm{mmol}, \quad 1$ equiv), (E)-4fluorocinnamaldehyde (2f) $(45.0 \mathrm{mg}, 39.3 \mu \mathrm{L}, 0.300 \mathrm{mmol}, 1.5$ equiv) and 2-aminophenol (12a) $\left(21.8 \mathrm{mg}, 0.200 \mathrm{mmol}, 1\right.$ equiv), at $25^{\circ} \mathrm{C}$ instead of $10{ }^{\circ} \mathrm{C}$ Purification by flash chromatography over silica gel (PE/EtOAc $80: 20$ ) afforded 29 as a yellow solid (33.8 $\mathrm{mg}, 0.092 \mathrm{mmol}, 46 \%$ yield, $>20: 1 d r, 91 \% e e$ )

TLC (PE/EtOAc 80:20) R $f 0.50$ (UV, vanillin).

HRMS (ESI) calc'd for $\left[\mathrm{C}_{21} \mathrm{H}_{21} \mathrm{FN}_{2} \mathrm{O}_{3}+\mathrm{H}\right]^{+}: 369.1609$, found: 369.1606 .

${ }^{1}$ H NMR (400 MHz, $\mathbf{C D C l}_{3}$ ) $\delta(\mathrm{ppm}) 7.22(\mathrm{dd}, J=8.3,5.6 \mathrm{~Hz}, 2 \mathrm{H}), 6.93(\mathrm{t}, J$ $=8.7 \mathrm{~Hz}, 2 \mathrm{H}), 6.83(\mathrm{td}, J=7.4,1.6 \mathrm{~Hz}, 1 \mathrm{H}), 6.75-6.57(\mathrm{~m}, 4 \mathrm{H}), 4.89(\mathrm{dd}, J$ $=7.6,1.7 \mathrm{~Hz}, 1 \mathrm{H}), 3.99(\mathrm{~d}, J=11.6 \mathrm{~Hz}, 1 \mathrm{H}), 3.60(\mathrm{~d}, J=11.6 \mathrm{~Hz}, 1 \mathrm{H}), 3.32$ $(\mathrm{s}, 3 \mathrm{H}), 3.01(\mathrm{~s}, 3 \mathrm{H}), 1.74(\mathrm{~s}, 3 \mathrm{H})$.

${ }^{13}$ C NMR (101 MHz, CDCl $) \delta(\mathrm{ppm}) 171.2(\mathrm{C}), 162.0$ (C, d, $J_{\mathrm{C}-\mathrm{F}}=245 \mathrm{~Hz}$ ), $149.5(\mathrm{C}), 137.7\left(\mathrm{C}, \mathrm{d}, J_{\mathrm{C}-\mathrm{F}}=3.0 \mathrm{~Hz}\right), 134.5(\mathrm{C}), 129.7\left(2 \mathrm{CH}, \mathrm{d}, J_{\mathrm{C}-\mathrm{F}}=7.8 \mathrm{~Hz}\right)$ $124.0(\mathrm{CH}), 121.5(\mathrm{CH}), 120.1(\mathrm{CH}), 115.4(\mathrm{CH}), 115.2(\mathrm{CH}), 108.6(\mathrm{CH})$, $106.8\left(2 \mathrm{CH}, \mathrm{d}, J_{\mathrm{C}-\mathrm{F}}=12.3 \mathrm{~Hz}\right), 100.6(\mathrm{C}), 61.2\left(\mathrm{CH}_{3}\right), 48.9(\mathrm{CH}), 42.5\left(\mathrm{CH}_{3}\right)$, $32.1(\mathrm{CH}), 21.0\left(\mathrm{CH}_{3}\right)$.

${ }^{19}$ F NMR (376 MHz, $\left.\mathrm{CDCl}_{3}\right) \delta(\mathrm{ppm})-115.75$.

HPLC Chiralpak IF, Heptane/Isopropanol 95:5, $25^{\circ} \mathrm{C}, 1.0 \mathrm{~mL} / \mathrm{min}, \lambda=254$ $\mathrm{nm}, \tau_{\text {major }}=7.65 \mathrm{~min}, \tau_{\text {minor }}=6.79 \mathrm{~min}$.

(1S,3R,4S,4aR)-3-(4-fluorophenyl)- $N$-methoxy- $N, 4$ a-dimethyl-1(phenylethynyl)-2,3,4,4a-tetrahydro- $1 H$-benzo[4,5]oxazolo[3,2a]pyridine-4-carboxamide (30). The three-component product 29 $(73.6 \mathrm{mg}, \quad 0.200 \mathrm{mmol}, 1$ equiv, $91 \%$ ee), potassium phenylethynyltrifluoroborate (24) $(49.9 \mathrm{mg}, 0.240 \mathrm{mmol}, 1.2$ equiv), scandium (III) triflate $(9.8 \mathrm{mg}, 0.020 \mathrm{mmol}, 10 \mathrm{~mol} \%)$ were stirred in $\mathrm{CH}_{2} \mathrm{Cl}_{2}(1 \mathrm{~mL})$ at $25^{\circ} \mathrm{C}$. After $4 \mathrm{~h}$, the crude solution was filtrated through a short pad of Celite and the solvent concentrated under vacuum. Purification by flash chromatography over silica gel (PE/Et0Ac 90:10) afforded 30 as a yellow solid (quantitative yield, $91 \% e e$ ).

TLC (PE/EtOAc 80:20) Rf 0.18 (UV, vanillin). 
${ }^{1} \mathbf{H}$ NMR (400 MHz, $\left.\mathbf{C D C l}_{3}\right) \delta(\mathrm{ppm}) 7.54-7.43(\mathrm{~m}, 2 \mathrm{H}), 7.39-7.31(\mathrm{~m}$, $3 \mathrm{H}), 7.20-7.10(\mathrm{~m}, 2 \mathrm{H}), 6.98-6.81(\mathrm{~m}, 3 \mathrm{H}), 6.76-6.59(\mathrm{~m}, 2 \mathrm{H}), 6.53(\mathrm{~d}$ $J=7.5 \mathrm{~Hz}, 1 \mathrm{H}), 5.00(\mathrm{dd}, J=4.8,2.1 \mathrm{~Hz}, 1 \mathrm{H}), 3.94(\mathrm{~d}, J=12.1 \mathrm{~Hz}, 1 \mathrm{H}), 3.76$ (dd, $J=11.6,4.1 \mathrm{~Hz}, 1 \mathrm{H}$ ), 3.68 (s, 3H), 2.89 (s, 3H), 2.13 (s, 3H), $2.11-2.03$ $(\mathrm{m}, 2 \mathrm{H})$.

${ }^{19}$ F NMR (376 MHz, $\left.\mathrm{CDCl}_{3}\right) \delta(\mathrm{ppm})-116.13$.

HPLC Chiralpak IA, Heptane/ethanol $80 / 20,25^{\circ} \mathrm{C}, 1.0 \mathrm{~mL} / \mathrm{min}, \mathrm{DAD}+$ polarimeter, $\tau_{\text {major }}=4.76 \mathrm{~min}, \tau_{\text {minor }}=6.95 \mathrm{~min}$.

(4aR)-4a-methyl-3-phenyl-12-tosyl-2,3,4,4a-tetrahydro-1 $\mathrm{H}-1,4-$ (epiminomethano)benzo[4,5]oxazolo[3,2-a]pyridin-11-one (36a) Prepared according to the general procedure B using 3-oxo- $N$ tosylbutanamide (35) $(48.3 \mathrm{mg}, \quad 0.200 \mathrm{mmol}, \quad 1$ equiv), $(E)$ cinnamaldehyde (2a) (38 $\mu \mathrm{L}, 0.300 \mathrm{mmol}, 1.5$ equiv) and 2 -aminophenol (12a) $(21.8 \mathrm{mg}, 0.200 \mathrm{mmol}, 1$ equiv). Purification by flash chromatography over silica gel $\left(\mathrm{CH}_{2} \mathrm{Cl}_{2} /\right.$ EtOAc $\left.99.5: 0.5\right)$ afforded product 36a as a yellowish solid $(52 \mathrm{mg}, 0.117 \mathrm{mmol}, 58 \%$ yield, $14: 1 \mathrm{dr}, 65 \%$ ee (major diastereomer), 61\% ee (minor diastereomer)).

TLC $\left(\mathrm{CH}_{2} \mathrm{Cl}_{2} /\right.$ EtOAc 99.5:0.5) R 0.59 (UV, $p$-anisaldehyde).

HRMS (ESI) calc'd for $\left[\mathrm{C}_{26} \mathrm{H}_{24} \mathrm{~N}_{2} \mathrm{O}_{4} \mathrm{~S}+\mathrm{H}\right]^{+}:$: 461.1530, found: 461.1531 .

${ }^{1} \mathrm{H}$ NMR (400 MHz, $\left.\mathbf{C D C l}_{3}\right) \delta(\mathrm{ppm}) 7.37-7.19(\mathrm{~m}, 8 \mathrm{H}), 7.09-7.00(\mathrm{~m}$, $4 \mathrm{H}), 6.54-6.51(\mathrm{~m}, 1 \mathrm{H}), 5.95(\mathrm{t}, J=2.5 \mathrm{~Hz}, 1 \mathrm{H}), 3.59-3.52(\mathrm{~m}, 1 \mathrm{H}), 3.10$ (d, $J=2.2 \mathrm{~Hz}, 1 \mathrm{H}), 2.91-2.82(\mathrm{~m}, 1 \mathrm{H}), 2.38(\mathrm{~s}, 3 \mathrm{H}), 2.38-2.34(\mathrm{~m}, 1 \mathrm{H}), 1.67$ (s, 3H).

${ }^{13}$ C NMR (101 MHz, CDCl $) ~ \delta(p p m) 166.1$ (C), 151.6 (C), 144.6 (C), 141.1 (C), 136.2 (C), 135.1 (C), $129.3(2 \mathrm{CH}), 129.2$ (2 CH), $128.6(2 \mathrm{CH}), 127.7$ $(\mathrm{CH}), 127.6(2 \mathrm{CH}), 125.8(\mathrm{CH}), 121.9(\mathrm{CH}), 117.5(\mathrm{CH}), 110.2(\mathrm{CH}), 102.1$ (C), $74.2(\mathrm{CH}), 56.2(\mathrm{CH}), 36.5\left(\mathrm{CH}\right.$ and $\left.\mathrm{CH}_{2}\right), 23.3\left(\mathrm{CH}_{3}\right), 21.8\left(\mathrm{CH}_{3}\right)$.

HPLC Chiralpak IA, Heptane/Ethanol 50:50, $1 \mathrm{~mL} / \mathrm{min}, \lambda=254 \mathrm{~nm}$, major diastereomer: $\tau_{\text {minor }}=12.65 \mathrm{~min}, \tau_{\text {major }}=23.70 \mathrm{~min}$, minor diastereomer $\tau_{\text {minor }}=21.32 \mathrm{~min}, \tau_{\text {major }}=10.69 \mathrm{~min}$.

$[\alpha]_{\mathbf{D}^{20}}=+158\left(\mathrm{c} 1.0, \mathrm{CHCl}_{3}\right)$

m.p. $=76-78{ }^{\circ} \mathrm{C}$.

(4aR)-7-chloro-4a-methyl-3-phenyl-12-tosyl-2,3,4,4a-tetrahydro1H-1,4-(epiminomethano)benzo[4,5] oxazolo[3,2-a]pyridin-11-one (36b). Prepared according to the general procedure B using 3-oxo- $N$ tosylbutanamide (35) $(48.3 \mathrm{mg}, \quad 0.200 \mathrm{mmol}, 1$ equiv), (E)cinnamaldehyde (2a) $(38 \mu \mathrm{L}, 0.300 \mathrm{mmol}, 1.5$ equiv) and 2 -amino-5chlorophenol (16b) $(21.8 \mathrm{mg}, 0.200 \mathrm{mmol}, 1$ equiv). Purification by flash chromatography over silica gel (PE/EtOAc 70:30) afforded product 36b as a yellowish solid (58 mg, $0.117 \mathrm{mmol}, 59 \%$ yield, $>20: 1 \mathrm{dr}, 59 \% \mathrm{ee}$ ).

TLC (PE/EtOAc 70:30) R $f 0.45$ (UV, $p$-anisaldehyde).

HRMS (ESI) calc'd for $\left[\mathrm{C}_{26} \mathrm{H}_{23} \mathrm{ClN}_{2} \mathrm{O}_{4} \mathrm{~S}+\mathrm{H}\right]^{+}: 495.1140$, found: 495.1136 .

${ }^{1}$ H NMR (400 MHz, CDCl $) \delta(\mathrm{ppm}) 7.41-7.25(\mathrm{~m}, 6 \mathrm{H}), 7.22(\mathrm{~d}, \mathrm{~J}=8.2 \mathrm{~Hz}$, $2 \mathrm{H}), 7.14(\mathrm{~d}, J=8.2 \mathrm{~Hz}, 2 \mathrm{H}), 7.06(\mathrm{~d}, J=8.2,1 \mathrm{H}), 6.95(\mathrm{dd}, J=8.2 \mathrm{~Hz}, J=2.0$ $\mathrm{Hz}, 1 \mathrm{H}), 6.36(\mathrm{~d}, J=2.0 \mathrm{~Hz}, 1 \mathrm{H}), 5.85(\mathrm{~d}, J=2.6 \mathrm{~Hz}, 1 \mathrm{H}), 3.51$ (ddd, $J=10.4$ $5.1,2.1 \mathrm{~Hz}, 1 \mathrm{H}$ ), 3.10 (d, $J=2.2 \mathrm{~Hz}, 1 \mathrm{H}$ ), 2.82 (ddd, $J=13.5,10.6,2.3 \mathrm{~Hz}$ 1H), 2.41 (s, 3H), 2.36 (ddd, $J=13.5 \mathrm{~Hz}, 5.2,3.2 \mathrm{~Hz}, 1 \mathrm{H}), 1.62(\mathrm{~s}, 3 \mathrm{H}$ ).

${ }^{13} \mathrm{C}$ NMR (101 MHz, $\mathrm{CDCl}_{3} \delta$ (ppm) 165.8 (C), 152.4 (C), 145.0 (C), 140.9 (C), 135.1 (C), 134.8 (C), 131.2 (C), $129.4(2 \mathrm{CH}), 129.3(2 \mathrm{CH}), 128.4(2$ (CH), $127.8(\mathrm{CH}), 127.6(2 \mathrm{CH}), 121.7(\mathrm{CH}), 117.9(\mathrm{CH}), 110.9(\mathrm{CH}), 103.7$ (C), $74.3(\mathrm{CH}), 56.1(\mathrm{CH}), 36.5\left(\mathrm{CH}_{2}\right), 36.4(\mathrm{CH}), 23.2\left(\mathrm{CH}_{3}\right), 21.8\left(\mathrm{CH}_{3}\right)$.

HPLC Chiralpak IE, Heptane/Ethanol 50:50, $1 \mathrm{~mL} / \mathrm{min}, \lambda=254 \mathrm{~nm}, \tau_{\text {minor }}$ $=8.19 \mathrm{~min}, \tau_{\text {major }}=11.71 \mathrm{~min}$.

$[\alpha]_{D^{20}}=+172\left(\mathrm{c} 1.0, \mathrm{CHCl}_{3}\right)$.

m.p. $=80-82^{\circ} \mathrm{C}$.

(4aR)-4a-methyl-3-phenyl-14-tosyl-2,3,4,4a-tetrahydro-1H-1,4(epiminomethano)naphtha[2',3':4,5]oxazolo[3,2-a]pyridin-13-one (36c). Prepared according to the general procedure B using 3-oxo- $\mathrm{N}$ tosylbutanamide (35) $(48.3 \mathrm{mg}, \quad 0.200 \mathrm{mmol}, 1$ equiv), (E)cinnamaldehyde (2a) (38 $\mu \mathrm{L}, 0.300 \mathrm{mmol}, 1.5$ equiv) and $3-$ aminonaphthalen-2-ol (16c) ( $31.8 \mathrm{mg}, 0.2 \mathrm{mmol}, 1$ equiv). Purification by flash chromatography over silica gel $\left(\mathrm{CH}_{2} \mathrm{Cl}_{2} / \mathrm{EtOAc} 99.5: 0.5\right)$ afforded product 36c as a yellowish solid (54 mg, $0.109 \mathrm{mmol}, 54 \%$ yield, $>20: 1 d r$, $65 \% e e)$.

TLC $\left(\mathrm{CH}_{2} \mathrm{Cl}_{2} /\right.$ EtOAc 99.5:0.5) R $f 0.59$ (UV, $p$-anisaldehyde).

HRMS (ESI) calc' $d$ for $\left[\mathrm{C}_{30} \mathrm{H}_{26} \mathrm{~N}_{2} \mathrm{O}_{4} \mathrm{~S}+\mathrm{H}\right]^{+}: 511.1686$, found: 511.1686 .

${ }^{1}{ }^{H}$ NMR (400 MHz, $\left.\mathbf{C D C l}_{3}\right)$ : $\delta(\mathrm{ppm}) 7.84-7.75(\mathrm{~m}, 1 \mathrm{H}), 7.57-7.51(\mathrm{~m}$, 1H), $7.48(\mathrm{~s}, 1 \mathrm{H}), 7.45-7.33(\mathrm{~m}, 4 \mathrm{H}), 7.33-7.27(\mathrm{~m}, 3 \mathrm{H}), 7 .(\mathrm{d}, J=8.2 \mathrm{~Hz}$ $2 \mathrm{H}), 6.62(\mathrm{~s}, 1 \mathrm{H}), 6.43(\mathrm{~d}, J=8.2 \mathrm{~Hz}, 2 \mathrm{H}), 6.06(\mathrm{t}, J=2.4 \mathrm{~Hz}, 1 \mathrm{H}), 3.58(\mathrm{ddd}$ $J=10.3,4.6,2.0 \mathrm{~Hz}, 1 \mathrm{H}), 3.19(\mathrm{~d}, J=2.0 \mathrm{~Hz}, 1 \mathrm{H}), 2.90$ (ddd, $J=13.0,10.5$ $\mathrm{Hz}, 1.9 \mathrm{~Hz}, 1 \mathrm{H}$ ), 2.46 (ddd, $J=13.5,4.4 \mathrm{~Hz}, 2.4 \mathrm{~Hz}, 1 \mathrm{H}$ ), 2.15 (s, 3H), 1.68 (s, $3 \mathrm{H})$.

${ }^{13}$ C NMR (101 MHz, CDCl 3 ): $\delta$ (ppm) 165.9 (C), 150.5 (C), 144.3 (C), 141.1 (C), 137.7 (C), 134.5 (C), 133.2 (C), 130.3 (C), $129.4(2 \mathrm{CH}), 128.8(2 \mathrm{CH})$, $128.0(2 \mathrm{CH}), 127.8(\mathrm{CH}), 127.6(3 \mathrm{CH}), 126.9(\mathrm{CH}), 125.6(\mathrm{CH}), 124.4(\mathrm{CH})$, $114.3(\mathrm{CH}), 104.8(\mathrm{CH}), 102.5(\mathrm{C}), 75.1(\mathrm{CH}), 56.6(\mathrm{CH}), 36.5\left(\mathrm{CH}_{2}\right), 36.4$ (CH), $23.8\left(\mathrm{CH}_{3}\right), 21.6\left(\mathrm{CH}_{3}\right)$.

HPLC Chiralpak IC, Heptane/Ethanol 80:20, $1 \mathrm{~mL} / \mathrm{min}, \lambda=254 \mathrm{~nm}, \tau_{\text {minor }}$ $=13.50 \mathrm{~min}, \tau_{\text {major }}=15.73 \mathrm{~min}$.

$[\boldsymbol{\alpha}]_{\mathbf{D}^{20}}=+145\left(\mathrm{c} 1.0, \mathrm{CHCl}_{3}\right)$.

m.p. $=88-90^{\circ} \mathrm{C}$.

(E)-3-(4-chlorobenzylidene)-2-oxo- $N$-tosylcyclopentane

carboxamide (40). In a 50-mL flask under argon atmosphere, $\beta$ ketoamide 31a (563 mg, $2.00 \mathrm{mmol}, 1$ equiv), 4-chlorobenzaldehyde (39) (281 mg, $2.00 \mathrm{mmol}, 1$ equiv) and $\mathrm{K}_{2} \mathrm{CO}_{3}(553 \mathrm{mg}, 4.00 \mathrm{mmol}, 2$ equiv) were stirred in dry $\mathrm{MeOH}(8 \mathrm{~mL})$ at room temperature for $14 \mathrm{~h}$. A $1 \mathrm{M}$ aqueous solution of $\mathrm{HCl}(30 \mathrm{~mL})$ was added and the reaction mixture extracted with EtOAc $(3 \times 30 \mathrm{~mL})$. Combined organic layers were washed with $1 \mathrm{M} \mathrm{HCl}(30 \mathrm{~mL})$ and brine $(30 \mathrm{~mL})$, dried over $\mathrm{Na}_{2} \mathrm{SO}_{4}$, filtered and concentrated under vacuum. The pale yellow solid was suspended in $\mathrm{Et}_{2} \mathrm{O}$ $(10 \mathrm{~mL})$, filtered, washed with $\mathrm{Et}_{2} \mathrm{O}(10 \mathrm{~mL})$ and dried under vacuum to afford product $\mathbf{4 0}$ as a white solid (570 $\mathrm{mg}, 1.41 \mathrm{mmol}, 71 \%$ yield, $~ 2: 1$ mixture of ketone and enol tautomers, with still some inseparable $p$ tosylamide inside).

TLC (Tol/EtOAC/AcOH 70:30:1) R $f 0.41$ (UV, $p$-anisaldehyde)

HRMS (ESI) calc' $\mathrm{d}$ for $\left[\mathrm{C}_{20} \mathrm{H}_{18} \mathrm{ClNO}_{4} \mathrm{~S}+\mathrm{H}\right]^{+}: 404.0718$, found: 404.0717 .

${ }^{1} \mathbf{H}$ NMR (300 MHz, $\left.\mathbf{C D C l}_{3}\right)$ : $\delta$ (ppm) ketone tautomer: $9.88(\mathrm{br} \mathrm{s}, 1 \mathrm{H}), 8.05$ - $7.84(\mathrm{~m}, 2 \mathrm{H}), 7.49-7.22(\mathrm{~m}, 5 \mathrm{H}), 7.17$ (d, $J=7.2 \mathrm{~Hz}, 2 \mathrm{H}), 3.29$ (app t, $J=$ $9.8 \mathrm{~Hz}, 1 \mathrm{H}), 2.99$ (ddt, $J=17.6,9.1,2.7 \mathrm{~Hz}, 1 \mathrm{H}), 2.78$ (ddd, $J=17.6,8.6,3.1$ $\mathrm{Hz}, 1 \mathrm{H}), 2.42$ (s, 3H), 2.39-2.21 (m, 2H); enol tautomer: $10.92(\mathrm{br} \mathrm{s}, 1 \mathrm{H})$ $8.05-7.84(\mathrm{~m}, 2 \mathrm{H}), 7.78(\mathrm{br} \mathrm{s}, 1 \mathrm{H}), 7.49-7.22(\mathrm{~m}, 6 \mathrm{H}), 6.89(\mathrm{~s}, 1 \mathrm{H}), 2.88$ (br s, 2H), 2.61 (br s, 2H), $2.46(\mathrm{~s}, 3 \mathrm{H})$.

${ }^{13}$ C NMR (75 MHz, CDCl 3 ): $\delta$ (ppm) ketone tautomer: 202.2 (C), 165.2 (C), 145.2 (C), 138.0 (C), 137.7 (C), 135.4 (CH), 134.8 (C), 133.1 (C), 132.2 (2 $\mathrm{CH}), 129.7(2 \mathrm{CH}), 129.4(2 \mathrm{CH}), 128.7(2 \mathrm{CH}), 53.9(\mathrm{CH}), 26.6\left(\mathrm{CH}_{2}\right), 21.8$ $\left(\mathrm{CH}_{2}\right), 21.6\left(\mathrm{CH}_{3}\right)$; enol tautomer: $172.5(\mathrm{C}), 166.8(\mathrm{C}), 145.4(\mathrm{C}), 137.7(\mathrm{C})$ 135.8 (C), 134.8 (C), 133.9 (C), $130.6(2 \mathrm{CH}), 129.8(2 \mathrm{CH}), 129.0(2 \mathrm{CH})$ $125.4(2 \mathrm{CH}) 124.8(\mathrm{CH}), 105.1(\mathrm{C}), 29.8\left(\mathrm{CH}_{2}\right), 26.2\left(\mathrm{CH}_{2}\right), 21.9\left(\mathrm{CH}_{3}\right)$.

m.p. $=174-176^{\circ} \mathrm{C}$.

3-bromo-2-oxo- $\boldsymbol{N}$-tosylcyclopentanecarboxamide (42). In a $100-\mathrm{mL}$ flask equipped with a dropping funnel under argon atmosphere, $\beta$ ketoamide 31a ( $1.41 \mathrm{~g}, 5.00 \mathrm{mmol}, 1$ equiv), was dissolved in glacial $\mathrm{AcOH}$ $(15 \mathrm{~mL})$ at room temperature. A solution of $\mathrm{Br}_{2}(283 \mu \mathrm{L}, 5.50 \mathrm{mmol}, 1.1$ equiv) in glacial $\mathrm{AcOH}(10 \mathrm{~mL})$ was placed in the dropping funnel and added dropwise. After $2 \mathrm{~h}$ of stirring at room temperature, acetone $(1 \mathrm{~mL})$ was added to quench the excess of $\mathrm{Br}_{2}$. After an additional hour at room temperature, the reaction mixture was diluted with water $(50 \mathrm{~mL})$ and extracted with EtOAc $(3 \times 50 \mathrm{~mL})$. Combined organic layers were washed with saturated $\mathrm{Na}_{2} \mathrm{~S}_{2} \mathrm{O}_{3}$ aqueous solution $(50 \mathrm{~mL})$, water $(50 \mathrm{~mL})$ and brine $(30 \mathrm{~mL})$, dried over $\mathrm{Na}_{2} \mathrm{SO}_{4}$, filtered and concentrated under vacuum. The pale yellow solid was suspended in $\mathrm{Et}_{2} \mathrm{O}(10 \mathrm{~mL})$, filtered, washed with $\mathrm{Et}_{2} \mathrm{O}(10 \mathrm{~mL})$ and dried under vacuum to afford product 42 as a white solid (1.35 g, $3.75 \mathrm{mmol}, 75 \%$ yield).

TLC (Tol/EtOAC/AcOH 80:20:1) R $f 0.36$ (UV, vanillin).

HRMS (ESI) calc' $\mathrm{d}$ for $\left[\mathrm{C}_{13} \mathrm{H}_{14} \mathrm{BrNO}_{4} \mathrm{~S}+\mathrm{H}\right]^{+}:$359.9900, found: 359.9901. 
${ }^{\mathbf{1}} \mathbf{H}$ NMR (400 MHz, d $\mathbf{6}$-DMSO): $\delta$ (ppm) 12.37 (br s, $1 \mathrm{H}, 1$ diastereomer), 10.76 (br s, 1 diastereomer), 7.86 (d, $J=8.4 \mathrm{~Hz}, 2 \mathrm{H}, 1$ diastereomer), 7.47 - $7.39(\mathrm{~m}, 2 \mathrm{H}, 2$ diastereromers), $5.08-5.02(\mathrm{~m}, 1 \mathrm{H}, 1$ diastereromer $)$ $4.75-4.63(\mathrm{~m}, 1 \mathrm{H}, 1$ diastereromer $), 3.45(\mathrm{~d}, J=8.5 \mathrm{~Hz}, 1 \mathrm{H}, 1$ diastereomer), 3.34 (d, $J=8.5 \mathrm{~Hz}, 1 \mathrm{H}, 1$ diastereomer), $2.48-1.94(\mathrm{~m}, 4 \mathrm{H}$, 2 diastereromers), 2.39 (s, 3H, 2 diastereomers).

Because of solubility and stability issues, conjugated with the presence of diastereomers and ketone-enol tautomerism, no clear ${ }^{{ }^{13} \mathrm{C}}$ NMR description could be obtained.

m.p. $=143-145^{\circ} \mathrm{C}$

(1R,3aS,6S,12aS)-1-bromo-13-tosyl-1,2,3,4,5,6-hexahydro-6,3a(epiminomethano)benzo[4,5]oxazolo[3,2-a]cyclopenta[b]pyridin14-one (45). Prepared according to the general procedure $C$ using 3 bromo-2-oxo- $N$-tosylcyclopentanecarboxamide $(\mathbf{4 2}) \quad(72.0 \mathrm{mg}, 0.200$ mmol, 1 equiv), acrolein (32) (27 $\mu \mathrm{L}, 0.400 \mathrm{mmol}, 2$ equiv) and 2 aminophenol (12a) $(32.7 \mathrm{mg}, 0.3 \mathrm{mmol}, 1.5$ equiv) with a reaction time of $72 \mathrm{~h}$. Purification by flash chromatography over silica gel (pure $\mathrm{CH}_{2} \mathrm{Cl}_{2}$ then $\left.\mathrm{CH}_{2} \mathrm{Cl}_{2} / \mathrm{EtOAc} 98: 2\right)$ afforded product $\mathbf{4 5}$ as a yellowish solid (49.2 mg, $0.101 \mathrm{mmol}, 50 \%$ yield, $>20: 1 \mathrm{dr}, 39 \% e e$ ).

\section{TLC $\left(\mathrm{CH}_{2} \mathbf{C l}_{2} /\right.$ EtOAc 95:5) Rf 0.93 (UV, $p$-anisaldehyde).}

HRMS (ESI) calc'd for $\left[\mathrm{C}_{22} \mathrm{H}_{21} \mathrm{BrN}_{2} \mathrm{O}_{4} \mathrm{~S}+\mathrm{H}\right]^{+}: 489.0478$, found: 489.0480

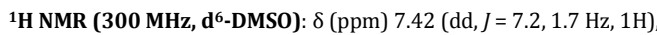

$7.17(\mathrm{~d}, J=8.1 \mathrm{~Hz}, 2 \mathrm{H}), 7.15-6.98(\mathrm{~m}, 4 \mathrm{H}), 6.60(\mathrm{dd}, J=7.4,1.4 \mathrm{~Hz}, 1 \mathrm{H})$, $6.01(\mathrm{~d} J=1.6 \mathrm{~Hz}, 1 \mathrm{H}), 4.44(\mathrm{dd} J=8.6,3.3 \mathrm{~Hz}, 1 \mathrm{H}), 2.88(\mathrm{dt} J=14.3,9.3$ $\mathrm{Hz}, 1 \mathrm{H}), 2.46-2.28(\mathrm{~m}, 3 \mathrm{H}), 2.34(\mathrm{~s}, 3 \mathrm{H}), 2.24-2.00(\mathrm{~m}, 2 \mathrm{H}), 1.91-1.77$ $(\mathrm{m}, 2 \mathrm{H})$.

${ }^{13}$ C NMR (101 MHz, CDCl $_{3}$ ): $\delta$ (ppm) 168.4 (C), 149.9 (C), 144.5 (C), 137.0 (C), $135.3(\mathrm{C}), 129.4(2 \mathrm{CH}), 128.4(2 \mathrm{CH}), 126.2(\mathrm{CH}), 122.5(\mathrm{CH}), 117.8$ $(\mathrm{CH}), 111.2(\mathrm{C}), 110.0(\mathrm{CH}), 77.2(\mathrm{CH}), 53.3(\mathrm{C}), 48.9(\mathrm{CH}), 33.7\left(\mathrm{CH}_{2}\right), 28.4$ $\left(\mathrm{CH}_{2}\right), 25.3\left(\mathrm{CH}_{2}\right), 23.3\left(\mathrm{CH}_{2}\right), 21.8\left(\mathrm{CH}_{3}\right)$.

HPLC Chiralpak ID, Heptane/Ethanol 80:20, $1 \mathrm{~mL} / \mathrm{min}, \lambda=205 \mathrm{~nm}, \tau_{\operatorname{mino}}$ $=12.83 \mathrm{~min}, \tau_{\text {major }}=14.54 \mathrm{~min}$.

$[\alpha]_{\mathrm{D}}{ }^{20}=+4.8\left(\mathrm{c} 0.5, \mathrm{CHCl}_{3}\right)$.

m.p. $=150-152^{\circ} \mathrm{C}$ (decomposition).

(2S,4aR,7aR)-1-(2-hydroxyphenyl)-7a-(phenylethynyl)-9-tosyl octahydro-2,4a-(epiminomethano)cyclopenta[b]pyridin-8-one (46) A mixture of product 34a (205 mg, $0.500 \mathrm{mmol}, 1$ equiv) and potassium phenylethynyltrifluoroborate (24) (312 mg, $1.50 \mathrm{mmol}, 3$ equiv) were suspended in dry $\mathrm{CH}_{2} \mathrm{Cl}_{2}(5 \mathrm{~mL})$ and cooled at $0{ }^{\circ} \mathrm{C}$. Boron trifluoride etherate $(126 \mu \mathrm{L}, 1.00 \mathrm{mmol}, 2$ equiv) was added dropwise and the reaction mixture allowed to reach room temperature, where it was stirred for $2 \mathrm{~h}$. The reaction was quenched with water $(10 \mathrm{~mL})$ and extracted with $\mathrm{CH}_{2} \mathrm{Cl}_{2}(3 \times 10 \mathrm{~mL})$. Combined organic layers were washed with water $(10$ $\mathrm{mL}$ ), dried over $\mathrm{Na}_{2} \mathrm{SO}_{4}$, filtered and concentrated under vacuum. Purification by flash chromatography over silica gel $\left(\mathrm{CH}_{2} \mathrm{Cl}_{2} / \mathrm{EtOAc}\right.$ 99.5:0.5 to 99:1) afforded product $\mathbf{4 6}$ as a brown foamy solid (151 mg, $0.295 \mathrm{mmol}, 59 \%$ yield, $>20: 1 \mathrm{dr}, 86 \% e e$ ).

TLC $\left(\mathrm{CH}_{2} \mathrm{Cl}_{2} /\right.$ EtOAc 98:2) $\mathrm{R} f 0.84$ (UV, $p$-anisaldehyde).

HRMS (ESI) calc'd for [ $\left.\mathrm{C}_{30} \mathrm{H}_{28} \mathrm{~N}_{2} \mathrm{O}_{4} \mathrm{~S}+\mathrm{H}\right]^{+}: 513.1843$, found: 513.1840 .

${ }^{1} \mathbf{H}$ NMR (300 MHz, $\mathbf{C D C l}_{3}$ ): $\delta$ (ppm) 7.97 (d, $\left.J=8.3 \mathrm{~Hz}, 2 \mathrm{H}\right), 7.44-7.29$ $(\mathrm{m}, 8 \mathrm{H}), 7.16(\mathrm{td}, J=8.0,1.4 \mathrm{~Hz}, 1 \mathrm{H}), 6.97(\mathrm{dd}, J=8.0,1.4 \mathrm{~Hz}, 1 \mathrm{H}), 6.81$ $(\mathrm{td}, J=8.0,1.5 \mathrm{~Hz}, 1 \mathrm{H}), 6.64(\mathrm{~s}, 1 \mathrm{H}), 5.57(\mathrm{dd}, J=3.9,1.4 \mathrm{~Hz}, 1 \mathrm{H}), 2.74-$ $2.33(\mathrm{~m}, 3 \mathrm{H}), 2.47(\mathrm{~s} ; 3 \mathrm{H}), 2.26-2.09(\mathrm{~m}, 1 \mathrm{H}), 1.94-1.49(\mathrm{~m}, 6 \mathrm{H})$

${ }^{13}$ C NMR (75 MHz, CDCl $_{3}$ ): $\delta$ (ppm) 172.3 (C), 153.5 (C), 145.4 (C), 135.8 (C), $131.9(\mathrm{C}), 131.7(2 \mathrm{CH}), 129.8(2 \mathrm{CH}), 129.0(\mathrm{CH}), 128.60(2 \mathrm{CH})$, $128.56(2 \mathrm{CH}), 128.5(\mathrm{CH}), 126.9(\mathrm{CH}), 121.9(\mathrm{C}), 120.2(\mathrm{CH}), 115.4(\mathrm{CH})$ $89.5(\mathrm{C}), 86.3(\mathrm{C}), 74.3(\mathrm{CH}), 67.8(\mathrm{C}), 59.1(\mathrm{C}), 37.6\left(\mathrm{CH}_{2}\right), 30.0\left(\mathrm{CH}_{2}\right), 26.0$ $\left(\mathrm{CH}_{2}\right), 23.6\left(\mathrm{CH}_{2}\right), 21.9\left(\mathrm{CH}_{3}\right), 20.1\left(\mathrm{CH}_{2}\right)$.

HPLC Chiralpak IA, Heptane/Ethanol 80:20, $1 \mathrm{~mL} / \mathrm{min}, \lambda=254 \mathrm{~nm}, \tau_{\text {major }}$ $=6.78 \mathrm{~min}, \tau_{\text {minor }}=8.24 \mathrm{~min}$.

$[\boldsymbol{\alpha}]_{\mathbf{D}}{ }^{20}=+12.3\left(\mathrm{c} 0.66, \mathrm{CHCl}_{3}\right)$.

m.p. $=181-183^{\circ} \mathrm{C}$.
(6S,8aR,11aS)-12-((2,6-dimethylphenyl)imino)-15-tosyl-7,8,9,10, 11,12-hexahydro-6H-6,8a-(epiminomethano)benzo[b]cyclopenta [2,3]pyrido[1,2-d][1,4]oxazin-14-one (48). A mixture of product 34a (41.1 mg, $0.100 \mathrm{mmol}, 1$ equiv) and 2,6-dimethylphenylisocyanide (47) (26.4 mg, $0.200 \mathrm{mmol}$, 2 equiv) were dissolved in dry $\mathrm{CH}_{2} \mathrm{Cl}_{2}(1 \mathrm{~mL})$ and cooled at $0{ }^{\circ} \mathrm{C}$. Boron trifluoride etherate $(25 \mu \mathrm{L}, 0.200 \mathrm{mmol}, 2$ equiv) was added dropwise and the reaction mixture allowed to reach room temperature, where it was stirred for $2 \mathrm{~h}$. The reaction was quenched with water $(10 \mathrm{~mL})$ and extracted with $\mathrm{CH}_{2} \mathrm{Cl}_{2}(3 \times 10 \mathrm{~mL})$. Combined organic layers were washed with water $(10 \mathrm{~mL})$, dried over $\mathrm{Na}_{2} \mathrm{SO}_{4}$, filtered and concentrated under vacuum. Purification by flash chromatography over silica gel (pure $\mathrm{CH}_{2} \mathrm{Cl}_{2}$ ) afforded product $\mathbf{4 8}$ as a brown foamy solid (42.7 $\mathrm{mg}, 0.079 \mathrm{mmol}, 79 \%$ yield, $>20: 1 d r, 94 \% e e)$.

TLC $\left(\mathrm{CH}_{2} \mathrm{Cl}_{2} /\right.$ EtOAc 98:2) R $f 0.92$ (UV, $p$-anisaldehyde).

HRMS (ESI) calc'd for [ $\left.\mathrm{C}_{31} \mathrm{H}_{31} \mathrm{~N}_{3} \mathrm{O}_{4} \mathrm{~S}+\mathrm{H}\right]^{+}: 542.2108$, found: 542.2106 .

${ }^{1}$ H NMR (400 MHz, $\left.\mathbf{C D C l}_{3}\right): \delta(\mathrm{ppm}) 7.99(\mathrm{~d}, J=8.4 \mathrm{~Hz}, 2 \mathrm{H}), 7.32(\mathrm{~d}, J=8.2$ $\mathrm{Hz}, 2 \mathrm{H}$ ), 7.27 (dd, $J=8.2,1.4 \mathrm{~Hz}, 1 \mathrm{H}$ ), 7.10 (ddd, $J=8.2,7.3,1.6 \mathrm{~Hz}, 1 \mathrm{H}$ ), 7.04 (br d, $J=7.5 \mathrm{~Hz}, 2 \mathrm{H}), 6.94$ (t, $J=7.5 \mathrm{~Hz}, 1 \mathrm{H}$ ), 6.87 (ddd, $J=8.5,7.2,1.4$ $\mathrm{Hz}, 1 \mathrm{H}), 6.81(\mathrm{dd}, J=8.2,1.5 \mathrm{~Hz}, 1 \mathrm{H}), 6.17(\mathrm{dd}, J=3.7,1.8 \mathrm{~Hz}, 1 \mathrm{H}), 3.14$ (ddd, $J=13.6,9.9,2.3 \mathrm{~Hz}, 1 \mathrm{H}$ ), $2.55-2.45(\mathrm{~m}, 2 \mathrm{H}), 2.43(\mathrm{~s}, 3 \mathrm{H}), 2.33-1.76$ $(\mathrm{m}, 12 \mathrm{H}), 1.04-0.92(\mathrm{~m}, 1 \mathrm{H})$.

${ }^{13}$ C NMR (101 MHz, CDCl $_{3}$ ): $\delta$ (ppm) 172.3 (C), 146.0 (C), 145.3 (C), 143.9 (C), 142.5 (C), 135.7 (C), 129.7 (2 CH), 128.6 (C), 128.5 (2 CH), 128.0 (2 $\mathrm{CH}), \sim 127.0$ (br, $2 \mathrm{C}), 124.3(\mathrm{CH}), 123.4(\mathrm{CH}), 121.9(\mathrm{CH}), 118.0(\mathrm{CH})$ $116.8(\mathrm{CH}), 71.7(\mathrm{CH}), 63.33(\mathrm{C}), 57.1(\mathrm{C}), 37.1\left(\mathrm{CH}_{2}\right), 28.1\left(\mathrm{CH}_{2}\right), 25.7$ $\left(\mathrm{CH}_{2}\right), 21.8\left(\mathrm{CH}_{3}\right), 20.6\left(\mathrm{CH}_{2}\right), 20.4\left(\mathrm{CH}_{2}\right), 18.7\left(\mathrm{br}, 2 \mathrm{CH}_{3}\right)$.

HPLC Chiralpak IF, Heptane/Ethanol 80:20, $1 \mathrm{~mL} / \mathrm{min}, \lambda=254 \mathrm{~nm}, \tau_{\text {minor }}$ $=10.09 \mathrm{~min}, \tau_{\text {major }}=11.65 \mathrm{~min}$.

$[\alpha]_{\mathbf{D}^{20}}=+37.5\left(\mathrm{c} 1.0, \mathrm{CHCl}_{3}\right)$.

m.p. $=198-200^{\circ} \mathrm{C}$

(2R,4aR,7aR)-1-(2-hydroxyphenyl)-7a-(phenylethynyl)octahydro2,4a-(epiminomethano)cyclopenta[b]pyridin-8-one (49). Product 34a $(35.9 \mathrm{mg}, 0.070 \mathrm{mmol}, 1$ equiv) was dissolved in dry THF $(0.6 \mathrm{~mL})$ and cooled at $-78^{\circ} \mathrm{C}$. A solution of sodium naphthalenide $(0.5 \mathrm{M}, 1.4 \mathrm{~mL}$ $0.700 \mathrm{mmol}, 10$ equiv) was added dropwise and the reaction mixture stirred at $-78{ }^{\circ} \mathrm{C}$ for $1 \mathrm{~h}$. The reaction was quenched with saturated aqueous $\mathrm{NH}_{4} \mathrm{Cl}(5 \mathrm{~mL})$ and extracted with EtOAc $(3 \times 5 \mathrm{~mL})$. Combined organic layers were washed with water $(5 \mathrm{~mL})$ and brine $(5 \mathrm{~mL})$, dried over $\mathrm{Na}_{2} \mathrm{SO}_{4}$, filtered and concentrated under vacuum. Purification by flash chromatography over silica gel $\left(\mathrm{CH}_{2} \mathrm{Cl}_{2} / \mathrm{EtOAc} 80: 20\right.$ to $\left.70: 30\right)$ afforded product 49 as a yellowish solid $(12.0 \mathrm{mg}, 0.034 \mathrm{mmol}, 48 \%$ yield, $>20: 1 d r, 86 \% e e$ ).

TLC ( $\mathbf{C H}_{2} \mathbf{C l}_{2} /$ EtOAc 70:30) R 0.43 (UV, $p$-anisaldehyde).

HRMS (ESI) calc' $\mathrm{d}$ for $\left[\mathrm{C}_{23} \mathrm{H}_{22} \mathrm{~N}_{2} \mathrm{O}_{2}+\mathrm{H}\right]^{+}: 359.1754$, found: 359.1754 .

$\left.{ }^{1} \mathrm{H} \mathrm{NMR} \mathrm{(400} \mathrm{MHz,} \mathbf{C D C l}_{3}\right): \delta(\mathrm{ppm}) 7.61(\mathrm{br} \mathrm{s}, 1 \mathrm{H}), 7.51-7.43(\mathrm{~m}, 2 \mathrm{H})$ $7.38-7.29(\mathrm{~m}, 4 \mathrm{H}), 7.07(\mathrm{td}, J=7.7,1.5 \mathrm{~Hz}, 1 \mathrm{H}), 7.02(\mathrm{~s}, 1 \mathrm{H}), 6.95(\mathrm{dd}, J=$ $8.1,1.6 \mathrm{~Hz}, 1 \mathrm{H}), 6.72(\mathrm{td}, J=7.7,1.6 \mathrm{~Hz}, 1 \mathrm{H}), 4.61(\mathrm{dd}, J=4.7,3.3 \mathrm{~Hz}, 1 \mathrm{H})$ 2.64 (ddd, $J=12.8,9.1,3.6 \mathrm{~Hz}, 1 \mathrm{H}), 2.58-2.47(\mathrm{~m}, 2 \mathrm{H}), 2.11-2.01(\mathrm{~m}$, 1H), $1.95-1.84(\mathrm{~m}, 3 \mathrm{H}), 1.78-1.70(\mathrm{~m}, 2 \mathrm{H}), 1.68-1.58(\mathrm{~m}, 1 \mathrm{H})$.

${ }^{13}$ C NMR (101 MHz, CDCl 3 ): $\delta$ (ppm) 175.7 (C), 153.2 (C), 133.7 (C), 131.8 (2 CH), $128.8(\mathrm{CH}), 128.6(2 \mathrm{CH}), 127.4(\mathrm{CH}), 125.4(\mathrm{CH}), 122.4(\mathrm{C}), 119.9$ $(\mathrm{CH}), 115.3(\mathrm{CH}), 91.0(\mathrm{C}), 85.5(\mathrm{C}), 68.7(\mathrm{CH}), 68.2(\mathrm{C}), 57.0(\mathrm{C}), 36.7$ $\left(\mathrm{CH}_{2}\right), 30.3\left(\mathrm{CH}_{2}\right), 26.1\left(\mathrm{CH}_{2}\right), 24.5\left(\mathrm{CH}_{2}\right), 20.5\left(\mathrm{CH}_{2}\right)$.

HPLC Chiralpak IE, Heptane/Ethanol 80:20, $1 \mathrm{~mL} / \mathrm{min}, \lambda=254 \mathrm{~nm}, \tau_{\operatorname{minor}}$ $=6.04 \mathrm{~min}, \tau_{\text {major }}=6.87 \mathrm{~min}$.

$[\boldsymbol{\alpha}]_{\mathrm{D}}{ }^{20}=+18.9\left(\mathrm{c} 0.5, \mathrm{CHCl}_{3}\right)$.

(3aR,6S,12a $R)$-13-((4-nitrophenyl)sulfonyl)-1,2,3,4,5,6-hexahydro6,3a-(epiminomethano)benzo[4,5] oxazolo[3,2-a]cyclopenta[b] pyridin-14-one (51). Prepared according to the general procedure $C$ using $N$-(4-nitrobenzenesulfonyl)-3-oxobutanamide (50) $(62.5 \mathrm{mg}, 0.200$ mmol, 1 equiv), acrolein (32) (27 $\mu \mathrm{L}, 0.400 \mathrm{mmol}, 2$ equiv) and 2 aminophenol (12a) (32.7 mg, $0.3 \mathrm{mmol}, 1.5$ equiv). Purification by flash chromatography over silica gel $\left(\mathrm{CH}_{2} \mathrm{Cl}_{2} /\right.$ EtOAc 99:1) afforded product $\mathbf{5 1}$ as a white solid $(66.3 \mathrm{mg}, 0.150 \mathrm{mmol}, 75 \%$ yield, $>20: 1 \mathrm{dr}, 59 \% e e$ ). 
TLC (PE/EtOAc 60:40) R $f 0.46$ (UV, $p$-anisaldehyde).

HRMS (ESI) calc'd for $\left[\mathrm{C}_{21} \mathrm{H}_{19} \mathrm{~N}_{3} \mathrm{O}_{6} \mathrm{~S}+\mathrm{H}\right]^{+}:$442.1067, found: 442.1070 .

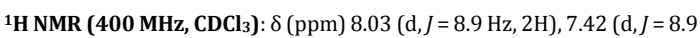
$\mathrm{Hz}, 2 \mathrm{H}), 7.18-7.13(\mathrm{~m}, 1 \mathrm{H}), 7.04-6.94(\mathrm{~m}, 2 \mathrm{H}), 6.39-6.29(\mathrm{~m}, 1 \mathrm{H}), 5.81$ $(\mathrm{t}, J=2.6 \mathrm{~Hz}, 1 \mathrm{H}), 2.44-2.31(\mathrm{~m}, 2 \mathrm{H}), 2.26-2.16(\mathrm{~m}, 1 \mathrm{H}), 2.15-2.06(\mathrm{~m}$, 1H), $2.03-1.87(\mathrm{~m}, 5 \mathrm{H}), 1.74-1.66(\mathrm{~m}, 1 \mathrm{H})$

${ }^{13}$ C NMR (101 MHz, CDCl 3 ): $\delta$ (ppm) 169.5 (C), 151.0 (C), 143.7 (C), 137.5 (C), $129.8(2 \mathrm{CH}), 126.2(\mathrm{CH}), 123.8(2 \mathrm{CH}), 121.9(\mathrm{CH}), 117.5(\mathrm{CH}), 112.6$ (C), $109.9(\mathrm{CH}), 77.5(\mathrm{CH}), 68.7(\mathrm{C}), 54.1(\mathrm{C}), 33.4\left(\mathrm{CH}_{2}\right), 28.8\left(\mathrm{CH}_{2}\right), 25.2$ $\left(\mathrm{CH}_{2}\right), 23.9\left(\mathrm{CH}_{2}\right), 19.3\left(\mathrm{CH}_{2}\right)$. Partial degradation of the product occured during the recording of the ${ }^{13} \mathrm{C}$ NMR spectra.

HPLC Chiralpak IB, Hexane/Ethanol 50:50, $10^{\circ} \mathrm{C}, 1 \mathrm{~mL} / \mathrm{min}, \lambda=254 \mathrm{~nm}$, $\tau_{\text {major }}=6.15 \mathrm{~min}, \tau_{\text {minor }}=7.93 \mathrm{~min}$.

\section{Acknowledgment}

We warmly thank Dr. Nicolas Vanthuyne and Marion Jean for HPLC analyses on chiral stationary phase, and the whole team of the Spectropole (www.spectropole.fr). Alban Falconnet is acknowledged for the prepartift (C) Marseille Université, Centrale Marseille, the CNRS, the Agence Nationale de la Recherche (ANR-07-CP2D-06, scholarship for M.M.S.D.; ANR-11-BS070014, scholarship for S. G.) and the China Scholarship Council is acknowledged (scholarship for H.Y.D.) is acknowledged.

\section{References}

(1) Vitaku, E.; Smith, D. T.; Njardarson, J. T. J. Med. Chem. 2014, 57, 10257-10274.

(2) (a) List, B.; Maruoka, K., Asymmetric Organocatalysis; Thieme: Stuttgart, 2012. (b) Dalko, P. I., Comprehensive Enantioselective Organocatalysis: Catalysts, Reactions, and Applications; Wiley-VCH: Weinheim, 2013.

(3) (a) Yu, J.; Shi, F.; Gong, L.-Z. Acc. Chem. Res. 2011, 44, 1156-1171. (b) Thu Pham, H.; Chataigner, I.; Renaud, J.-L. Curr. Org. Chem. 2012, 16, 1754-1775. (c) Wan, J.-P.; Liu, Y. RSC Adv. 2012, 2, 97639777.

(4) (a) Moreau, J.; Duboc, A.; Hubert, C.; Hurvois, J.-P.; Renaud, J.-L. Tetrahedron Lett. 2007, 48, 8647-8650. (b) Jiang, J.; Yu, J.; Sun, X.X.; Rao, Q.-Q.; Gong, L.-Z. Angew. Chem. Int. Ed. 2008, 47, 24582462.

(5) (a) Hayashi, Y.; Gotoh, H.; Hayashi, T.; Shoji, M. Angew. Chem. Int. Ed. 2005, 44, 4212-4215. (b) Franke, P. T.; Johansen, R. L.; Bertelsen, S.; Jørgensen, K. A. Chem. Asian J. 2008, 3, 216-224.

(6) (a) Jiang, B.; Rajale, T.; Wever, W.; Tu, S.-J.; Li, G. Chem. Asian J. 2010, 5, 2318-2335. (b) Touré, B. B.; Hall, D. G. Chem. Rev. 2009, 109, 4439-4486. (c) Ruijter, E.; Scheffelaar, R.; Orru, R. V. A. Angew. Chem. Int. Ed. 2011, 50, 6234-6246. (d) Climent, M. J.; Corma, A.; Iborra, S. RSC Adv. 2012, 2, 16-58. (e) Dömling, A.; Wang, W.; Wang, K. Chem. Rev. 2012, 112, 3083-3135. (f) Brauch, S.; van Berkel, S. S.; Westermann, B. Chem. Soc. Rev. 2013, 42, 4948-4962. (g) Cioc, R. C.; Ruijter, E.; Orru, R. V. A. Green Chem. 2014, 16, 2958-2975. (h) Zhu, J.; Wang, Q.; Wang, M.-X. Multicomponent Reactions in Organic Synthesis; Wiley-VCH: Weinheim, 2014

(7) (a) Simon, C.; Constantieux, T.; Rodriguez, J. Eur. J. Org. Chem. 2004, 4957-4980. (b) Liéby-Muller, F.; Simon, C.; Constantieux, T.; Rodriguez, J. QSAR Comb. Sci. 2006, 25, 432-438. (c) Sanchez Duque, M. M.; Allais, C.; Isambert, N.; Constantieux, T.; Rodriguez, J. Top. Heterocycl. Chem. 2010, 23, 227-277. (d) Coquerel, Y.; Boddaert, T.; Presset, M.; Mailhol, D.; Rodriguez, J., Multiple BondForming Transformations: The Key Concept toward Eco-

Compatible Synthetic Organic Chemistry. In Ideas in Chemistry and Molecular Sciences; Pignataro, B., Eds.; Wiley-VCH: Weinheim, 2010; 187-202. (e) Green, N. J.; Sherburn, M. S. Aust. J. Chem. 2013, 66, 267-283. (f) Bonne, D.; Constantieux, T.; Coquerel, Y.; Rodriguez, J. Chem. Eur. J. 2013, 19, 2218-2231. (g) Bugaut, X. Bonne, D.; Coquerel, Y.; Rodriguez, J.; Constantieux, T. Curr. Org. Chem. 2013, 17, 1920-1928. (h) Bugaut, X.; Constantieux, T.; Coquerel, Y.; Rodriguez, J., 1,3-Dicarbonyls in Multicomponent Reactions. In Multicomponent Reactions in Organic Synthesis; Zhu, J.; Wang, Q.; Wang, M.-X., Eds.; Wiley-VCH: Weinheim, 2014; 109158. (i) Stereoselective Multiple Bond-Forming Transformations in Organic Synthesis, Eds.: Rodriguez, J.; Bonne, D. John Wiley \& Sons, Inc., Hoboken, NJ, USA, 2015.

(8) For a review on organocatalytic enantioselective Michael additions, see: Zhang, Y.; Wang, W. Catal. Sci. Tech. 2012, 2, 42-53.

(9) (a) Du, H.; Rodriguez, J.; Bugaut, X.; Constantieux, T. Adv. Synth Catal. 2014, 356, 851-856. (b) For the racemic version, see: LiébyMuller, F.; Constantieux, T.; Rodriguez, J. Synlett 2007, 1323-1325.

(10) Dudognon, Y.; Du, H.; Rodriguez, J.; Bugaut, X.; Constantieux, T. Chem. Commun. 2015, 51, 1980-1982.

(11) (a) Sanchez Duque, M. M.; Baslé, O.; Génisson, Y.; Plaquevent, J.-C.; Bugaut, X.; Constantieux, T.; Rodriguez, J. Angew. Chem. Int. Ed. 2013, 52, 14143-14146. For racemic versions, see: (b) LiébyMuller, F.; Constantieux, T.; Rodriguez, J. J. Am. Chem. Soc. 2005, 127, 17176-17177. (c) El Asri, Z.; Génisson, Y.; Guillen, F.; Baslé, O.; Isambert, N.; Sanchez Duque, M. M.; Ladeira, S.; Rodriguez, J.; Constantieux, T.; Plaquevent, J.-C. Green Chem. 2011, 13, 25492552.

(12) (a) For a pseudo-three-component reaction, see: Bertelsen, $S$. Johansen, R. L.; Jørgensen, K. A. Chem. Commun. 2008, 3016-3018. (b) For a trimolecular coupling involving the in-situ generation of an $\alpha, \beta$-unsaturated imine, see: Jiang, J.; Yu, J.; Sun, X.-X.; Rao, Q.-Q.; Gong, L.-Z. Angew. Chem. Int. Ed. 2008, 47, 2458-2462. (c) For a transformation with a nitroolefin as the Michael acceptor, see: Wang, Y.; Han, R.-G.; Zhao, Y.-L.; Yang, S.; Xu, P.-F.; Dixon, D. J. Angew. Chem. Int. Ed. 2009, 48, 9834-9838. (d) For the synthesis of seven-membered rings from $\beta$-diketones, phenylene diamines and oxindoles, see: Wang, Y.; Shi, F.; Yao, X.-X.; Sun, M.; Dong, L.; Tu, S.-J. Chem. Eur. J. 2014, 20, 15047-15052. (e) For the synthesis of highly substituted spirooxindoles by a four-component coupling, see: Huang, X.; Pham, K.; Yi, W.; Zhang, X.; Clamens, C.; Hyatt, J. H.; Jasinsk, J. P.; Tayvah, U.; Zhang, W. Adv. Synth. Catal. 2015, 357, 3820-3824. (f) For a recent sequential one-pot coupling with benzylamine as ammonia surrogate, see: Rong, C.; Pan, H.; Liu, M.; Tian, H.; Shi, Y. Chem. Eur. J. 2016, 22, 2887-2891.

(13) We have also recently described early results of organocatalytic multicomponent reactions with $\alpha$-substituted enals, however with low enantioselectivities: Du, H.; Rodriguez, J.; Bugaut, X.; Constantieux, T. Synthesis 2015, 47, 2188-2198. These results will not be further discussed in this Feature Article.

(14) There is also a possibility to prepare in a stepwise fashion suitably substituted 4-aryl-1,4-dihydropyridines with a free nitrogen atom and to oxidize them into axially chiral 4-arylpyridine with a central-to-axial conversion of chirality: Quinonero, O.; Jean, M.; Vanthuyne, N.; Roussel, C.; Bonne, D.; Constantieux, T.; Bressy, C.; Bugaut, X.; Rodriguez, J. Angew. Chem. Int. Ed. 2016, 55, 14011405.

(15) (a) For the original report, see: Franzén, J.; Fisher, A. Angew. Chem Int. Ed. 2009, 48, 787-791. (b) For a review, see ref. 7g.

(16) (a) For the original report, see: Jin, Z.; Wang, X.; Huang, H.; Liang X.; Ye, J. Org. Lett. 2011, 13, 564-567. (b) For a review, see ref. 7g.

(17) Nigst, T. A.; Westermaier, M.; Ofial, A. R.; Mayr, H. Eur. J. Org. Chem. 2008, 2369-2374.

(18) (a) Zhang, W.; Franzén, J. Adv. Synth. Catal. 2010, 352, 499-518. (b) Wu, X.; Dai, X.; Nie, L.; Fang, H.; Chen, J.; Ren, Z.; Cao, W.; Zhao, G. Chem. Commun.2010, 46, 2733-2735. (c) Zhang, W.; Bah, J.; Wohlfarth, A.; Franzén, J. Chem. Eur. J. 2011, 17, 13814-13824.

(19) (a) Xu, L.-W.; Li, L.; Shi, Z.-H. Adv. Synth. Catal. 2010, 352, 243-279. (b) Jensen, K. L.; Dickmeiss, G.; Jiang, H.; Albrecht, Ł.; Jørgensen, K. 
A. Acc. Chem. Res. 2012, 45, 248-264. (c) Meninno, S.; Lattanzi, A. Chem. Commun. 2013, 49, 3821-3832.

(20) (a) Du, H.; Rodriguez, J.; Bugaut, X.; Constantieux, T. Chem. Eur. J. 2014, 20, 8458-8466. For related reports, see: (b) Horitsugi, N.; Kojima, K.; Yasui, K.; Sohtome, Y.; Nagasawa, K. Asian J. Org. Chem. 2014, 3, 445-448. (c) Goldys, A. M.; Núñez, M. G.; Dixon, D. J. Org. Lett. 2014, 16, 6294-6297.

(21) (a) Alemán, J.; Marcos, V.; Marzo, L.; García Ruano, J. L. Eur. J. Org. Chem. 2010, 4482-4491. (b) Enders, D.; Grossmann, A.; Huang, H.; Raabe, G. Eur. J. Org. Chem. 2011, 4298-4301.

(22) Liu, Y.-Z.; Zhang, J.; Xu, P.-F.; Luo, Y.-C. J. Org. Chem. 2011, 76, 75517555.

(23) For seminal work in this direction in the racemic series, see: Simon, C.; Peyronel, J.-F.; Rodriguez, J. Org. Lett. 2001, 3, 2145-2148.

(24) For a related sequential reaction, see: Rueping, M.; Volla, C. M. R.; Bolte, M.; Raabe, G. Adv. Synth. Catal. 2011, 353, 2853-2859.

(25) For a non-enantioselective reaction related reaction, see: Wan, J.P.; Zhong, S.; Liu, Y. Synthesis 2015, 47, 3611-3617.

(26) (a) For a key seminal study, see: Evans, D. A.; Ennis, M. D.; Le, T.; Mandel, N.; Mandel, G. J. Am. Chem. Soc. 1984, 106, 1154-1156. For applications in enantioselective catalysis, see: (b) Liu, Q.; Rovis, T. Org. Lett. 2009, 11, 2856-2859. (c) Kim, M.-h.; Choi, S.-h.; Lee, Y.-J.; Lee, J.; Nahm, K.; Jeong, B.-S.; Park, H.-g.; Jew, S.-s. Chem. Commun. 2009, 782-784. (d) Shin, S. H.; Baek, E. H.; Hwang, G.-S.; Ryu, D. H. Org. Lett. 2015, 17, 4746-4749.

(27) See experimental part for details.

(28) Elsner, P.; Jiang, H.; Nielsen, J. B.; Pasi, F.; Jørgensen, K. A. Chem. Commun. 2008, 5827-5829.

(29) (a) This reation was already known with conventional heating: Sato, M.; Kanuma, N.; Kato, T. Chem. Pharm. Bull. 1982, 30, 13151321; for examples of the advantage of microwave irradiation for the synthesis of 1,3-dicarbonyl compounds through ketoketenes intermediates, see: (b) Presset, M.; Coquerel, Y.; Rodriguez, J. J. Org. Chem. 2009, 74, 415-418. (c) Presset, M.; Mailhol, D.; Coquerel, Y.; Rodriguez, J. Synthesis 2011, 2549-2552. (d) Mohanan, K.; Presset, M.; Mailhol, D.; Coquerel, Y.; Rodriguez, J. Chem. Eur. J. 2012, 18, 9217-9220. (e) Dudognon, Y.; Presset, M.; Rodriguez, J.; Coquerel, Y.; Bugaut, X.; Constantieux, T. Chem. Commun. 2016, 52, 30103013.

(30) Jurberg, I. D.; Peng, B.; Wöstefeld, E.; Wasserloos, M.; Maulide, N. Angew. Chem. Int. Ed. 2012, 51, 1950-1953.

(31) For other examples of combination of multicomponent reactions, see: (a) Paravidino, M.; Scheffelaar, R.; Schmitz, R. F.; de Kanter, F. J. J.; Groen, M. B.; Ruijter, E.; Orru, R. V. A. J. Org. Chem. 2007, 72, 10239-10242. (b) Scheffelaar, R.; Nijenhuis, R. A. K.; Paravidino, M.; Lutz, M.; Spek, A. L.; Ehlers, A. W.; de Kanter, F. J. J.; Groen, M. B.; Orru, R. V. A.; Ruijter, E. J. Org. Chem. 2009, 74, 660-668. (c) Elders, N.; van der Born, D.; Hendrickx, L. J. D.; Timmer, B. J. J.; Krause, A.; Janssen, E.; de Kanter, F. J. J.; Ruijter, E.; Orru, R. V. A. Angew. Chem. Int. Ed. 2009, 48, 5856-5859. (d) Znabet, A.; Polak, M. M.; Janssen, E.; de Kanter, F. J. J.; Turner, N. J.; Orru, R. V. A.; Ruijter, E. Chem. Commun. 2010, 46, 7918-7920. (e) Deng, X.-X.; Du, F.-S.; Li, Z.-C. ACS Macro Lett. 2014, 3, 667-670.

(32) For a review, see: Kouznetsov, V. V. Tetrahedron 2009, 65, 27212750.

(33) For means of comparison in ${ }^{19} \mathrm{~F}$ NMR, an authentic sample of product $\mathbf{3 0}$ was prepared by the treatment of $\mathbf{2 9}$ with potassium phenylethynyltrifluoroborate $\mathbf{2 4}$ in the presence of Sc(OTf $)_{3}$. See experimental part for details.

(34) The known trapping of the activated iminium ion by the organotrifluoroborate salt was not observed. See: Lee, S.; MacMillan, D. W. C. J. Am. Chem. Soc. 2007, 129, 15438-15439.
(35) For recent reviews on organo- and metal- dual catalysis, see: (a) Du, Z.; Shao, Z. Chem. Soc. Rev. 2013, 42, 1337-1378. (b) Lohr, T. L.; Marks, T. J. Nat. Chem. 2015, 7,, 477-482.

(36) (a) Sanchez Duque, M. d. M.; Baslé, O.; Isambert, N.; Gaudel-Siri, A.; Génisson, Y.; Plaquevent, J.-C.; Rodriguez, J.; Constantieux, T. Org Lett. 2011, 13 3296-3299. (b) Mohanan, K.; Coquerel, Y; Rodriguez, J. Org. Lett. 2012, 14, 4686-4689. (c) Mailhol, D.; Sanchez Duque, M. d. M.; Raimondi, W.; Bonne, D.; Constantieux, T.; Coquerel, Y.; Rodriguez, J. Adv. Synth. Catal. 2012, 354, 3523-3532. (d) Mailhol, D.; Castillo, J.-C.; Mohanan, K.; Abonia, R.; Coquerel, Y.; Rodriguez, J. ChemCatChem 2013, 5, 1192-1199. (e) Goudedranche, S.; Bugaut, X.; Constantieux, T.; Bonne, D.; Rodriguez, J. Chem. Eur. J. 2014, 20, 410-415. (f) Quintard, A.; Cheshmedzhieva, D.; Sanchez Duque, M. d. M.; Gaudel-Siri, A.; Naubron, J.-V.; Génisson, Y.; Plaquevent, J.-C.; Bugaut, X.; Rodriguez, J.; Constantieux, T. Chem. Eur. J. 2015, 21, 778-790.

(37) For related studies by other research groups, see: (a) Jakubec, $P$ Helliwell, M.; Dixon, D. J. Org. Lett. 2008, 10, 4267-4270. (b) Paixão, M. W.; Nielsen, M.; Jacobsen, C. B.; Jørgensen, K. A. Org. Biomol. Chem. 2008, 6, 3467-3470. (c) Yang, T.; Ferrali, A.; Sladojevich, F.; Campbell, L.; Dixon, D. J. J. Am. Chem. Soc. 2009, 131, 9140-9141. (d) Jakubec, P.; Cockfield, D. M.; Dixon, D. J. J. Am. Chem. Soc. 2009, 131, 16632-16633. (e) Jakubec, P.; Cockfield, D. M.; Hynes, P. S.; Cleator, E.; Dixon, D. J. Tetrahedron: Asymmetry 2011, 22, 11471155. (f) Dai, X.; Wu, X.; Fang, H.; Nie, L.; Chen, J.; Deng, H.; Cao, W.; Zhao, G. Tetrahedron 2011, 67, 3034-3040. (g) Kyle, A. F.; Jakubec P.; Cockfield, D. M.; Cleator, E.; Skidmore, J.; Dixon, D. J. Chem. Commun. 2011, 47, 10037-10039. (h) Chen, X.; Zhu, W.; Qian, W.; Feng, E.; Zhou, Y.; Wang, J.; Jiang, H.; Yao, Z.--J.; Liu, H. Adv. Synth Catal. 2012, 354, 2151-2156. (i) Wu, X.; Liu, Q.; Fang, H.; Chen, J.; Cao, W.; Zhao, G. Chem. Eur. J. 2012, 18, 12196-12201. (j) De Fusco, C.; Meninno, S.; Tedesco, C.; Lattanzi, A. Org. Biomol. Chem. 2013, 11, 896-899.(k) Huang, Y.-m.; Zheng, C.-w.; Zhao, G. J. Org. Chem. 2015, 80, 3798-3805. (l) Zeng, X.-M.; Meng, C.-Y.; Bao, J.-X.; Xu, D.C.; Xie, J.-W.; Zhu, W.-D. J. Org. Chem. 2015, 80, 11521-11528. (m) Goodman, C. G.; Johnson, J. S. J. Am. Chem. Soc. 2015, 137, 1457414577.

(38) (a) Okino, T.; Hoashi, Y.; Takemoto, Y. J. Am. Chem. Soc. 2003, 125 12672-12673. (b) Okino, T.; Hoashi, Y.; Furukawa, T.; Xu, X.; Takemoto, Y. J. Am. Chem. Soc. 2005, 127, 119-125.

(39) Relative configuration of the additional stereogenic center was attributed by nOeSY analysis. See supporting information for details.

(40) Charonnet, E.; Filippini, M.-H.; Rodriguez, J. Synthesis 2001, 788804.

(41) nOeSY analysis shows correlations for the hydrogen atom linked on the carbon atom bearing the bromine atom only with its direct neighbors. The absence of longer distance correlations is however not conclusive for the relative configuration of the additional stereocenter.

(42) For reviews on multicomponent reactions with isonitriles: (a) Ugi, I.; Werner, B.; Dömling, A. Molecules 2003, 8, 53-66. (b) Dömling, A. Chem. Rev. 2006, 106, 17-89. (c) El Kaïm, L.; Grimaud, L., UgiSmiles and Passerini-Smiles Couplings. In Multicomponent Reactions in Organic Synthesis; Zhu, J.; Wang, Q.; Wang, M.-X., Eds.; Wiley-VCH: Weinheim, 2014; 73-108. (d) Váradi, A.; Palmer, T. Notis Dardashti, R.; Majumdar, S. Molecules 2016, 21, 19-41.

(43) Molander, G. A.; Katona, B. W.; Machrouhi, F. J. Org. Chem. 2002, 67, 8416-8424.

(44) Ley, S. V.; Smith, S. C.; Woodward, P. R. Tetrahedron 1992, 48, 1145-1174. 